\title{
Annual Report to Texas State University-San Marcos, Hays County, Texas, for Texas Antiquities Permit No. 5509
}

Carole A. Leezer

Center for Archaeological Studies

Follow this and additional works at: https://scholarworks.sfasu.edu/ita

Part of the American Material Culture Commons, Archaeological Anthropology Commons, Environmental Studies Commons, Other American Studies Commons, Other Arts and Humanities Commons, Other History of Art, Architecture, and Archaeology Commons, and the United States History Commons

Tell us how this article helped you.

This Article is brought to you for free and open access by the Center for Regional Heritage Research at SFA ScholarWorks. It has been accepted for inclusion in Index of Texas Archaeology: Open Access Gray Literature from the Lone Star State by an authorized editor of SFA ScholarWorks. For more information, please contact cdsscholarworks@sfasu.edu. 


\section{Annual Report to Texas State University-San Marcos, Hays County, Texas, for}

Texas Antiquities Permit No. 5509

\section{Creative Commons License}

\section{(c) (i) (2)}

This work is licensed under a Creative Commons Attribution-Share Alike 3.0 License. 


\title{
Annual Report to \\ Texas State University-San Marcos, \\ Hays County, Texas, \\ for Texas Antiquities Permit No. 5509
}

\author{
Assembled by \\ Carole A. Leezer \\ with contributions by \\ Antonio Padilla, David M. Yelacic, Julian A. Sitters, \\ Carole A. Leezer, and Jon C. Lohse
}

Principal Investigator: Jon C. Lohse

Texas Antiquities Permit No. 5509

Archaeological Studies Report No. 26

CENTER FOR ARCHAEOLOGICAL STUDIES

Texas State University-San Marcos 
The following information is provided in accordance with the General Rules of Practice and Procedures, Title 13, Chapter 26, Texas Administrative Code:

1. Type of investigation: Surface survey, subsurface survey, backhoe trench excavation, archaeological monitoring, and archival research

2. Project name: Annual Report to Texas State University for Texas Antiquities Permit No. 5509

3. County: Hays

4. Principal Investigator: Jon C. Lohse

5. Name and location of sponsoring agency: Texas State University-San Marcos

6. Published by the Center for Archaeological Studies, Texas State University-San Marcos, 601 University Drive, San Marcos, Texas, 78666-4616 (2011)

Texas State University-San Marcos is a member of the Texas State University System

Copyright (C) 2011 by the Center for Archaeological Studies at Texas State University-San Marcos

All rights reserved.

No part of this book may be reproduced or utilized in any form or by any means, electronic or mechanical, including photocopying, recording, or by any information storage and retrieval system without permission in writing.

For further information on this and other publications by the Center for Archaeological Studies, please contact:

Center for Archaeological Studies

Texas State University-San Marcos

601 University Drive

San Marcos, TX 78666-4616

www.txstate.edu/anthropology/cas/

Editor: Maggie McClain

Cover photograph: Overview of Center for Research Commercialization project area.

Printed in the United States of America

by

Ginny's Printing Inc., Austin 


\section{Management Summary}

Project Title: Annual Report to Texas State University for Texas Antiquities Permit No. 5509

Project Description: Surface survey, subsurface survey, backhoe trench excavation, archaeological monitoring, and archival research

Local Sponsor: Texas State University-San Marcos

Institution: Center for Archaeological Studies, Texas State University-San Marcos

Principal Investigator: Jon C. Lohse

Project Archaeologist: Antonio Padilla, David Yelacic, Julian A. Sitters, and Carole Leezer

Crew Members: David Yelacic, Sarah Scogin, Jacob Hooge, Veronica Suarez, Julian A. Sitters

Texas Antiquities Permit: 5509

Dates of Work: January 2010 through December 2010

Purpose of Work: Archaeological investigations of nine properties and archival research covering seven properties owned by the University under Texas Antiquities Permit No. 5509 during the year 2010. Investigations were conducted in association with a Memorandum of Agreement between the Texas Historical Commission (THC) and the University, in which CAS is authorized to determine whether proposed undertakings on University properties have the potential to negatively impact cultural resources, and if so, to recommend to the University courses of future action that may avoid or offset that impact.

Number of Sites: 2 - 41HY477 and State Archeological Landmark 41HY161

Curation: Center for Archaeological Studies, Texas State University-San Marcos

Comments: With the exception of the identified possible historic structure, Hornsby Hall, and two properties that require archaeological investigation prior to construction, CAS recommends that the University be granted cultural resource clearance for the proposed construction/demolition activities. 


\section{Abstract}

The Center for Archaeological Studies (CAS) at Texas State University-San Marcos (University) conducted archaeological survey and monitoring investigations on nine properties owned by the University under Texas Antiquities Permit No. 5509 during the year 2010. Investigations were conducted to determine if intact cultural resources were present within the project areas and if they would be adversely affected by construction and development. Under a Memorandum of Agreement (MOA) between the Texas Historical Commission (THC) and the University, CAS is authorized to determine whether proposed undertakings have the potential to negatively impact cultural resources, and if so, to recommend to the University courses of future action that may avoid or offset that impact.

Investigations were coordinated with and reported upon individually with the THC through interim reports. Clearance in regards to cultural resources was provided by the THC through these interim reports. One previously unrecorded archaeological site, 41HY477, was recorded during investigations of the Center for Research and Commercialization. Due to the disturbed nature of the site and low integrity of deposits, the site was determined to have no research potential. Cultural deposits encountered during the excavation of backhoe trenches for archaeological investigations of the Performing Arts Center Complex were considered to be an extension of adjacent State Archeological Landmark 41HY161; site boundaries were redrafted to incorporate these newly uncovered deposits. These deposits were also considered not to be intact and possess little research potential.

In addition, archival research outside of the scope of the MOA was conducted on an additional seven properties under consideration of future development by the University. This archival research was not a part of the archaeological investigations conducted under Texas Antiquities Permit No. 5509, but is presented in this report along with the findings of the archaeological investigations. These properties were examined to determine if they possessed historical significance from an historical perspective, and whether they were associated with people or events that were important in local, regional, or state history. Any buildings or site locations determined to have the potential to possess historical and or archaeological significance will be coordinated separately with the THC. During archival investigations, a possible historically significant structure, Hornsby Hall, was identified. It is recommended that coordination with the THC/State Historic Preservation Officer (SHPO) be initiated regarding the proposed demolition of this structure. The proposed location of the Alumni Visitor Center was also identified as possessing a high potential for buried prehistoric deposits. Archaeological investigations were recommended for this location prior to any development. 


\section{Table of Contents}

Management Summary .......................................................................................................

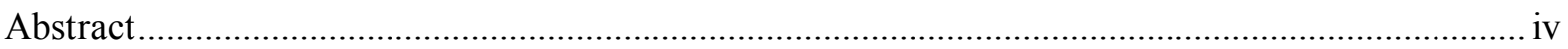

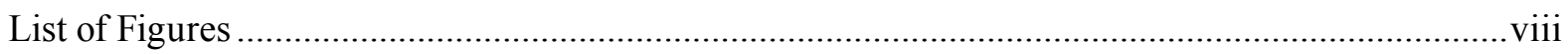

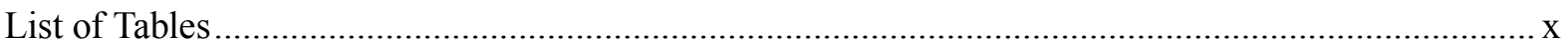

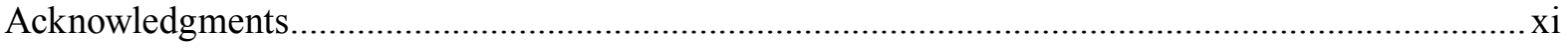

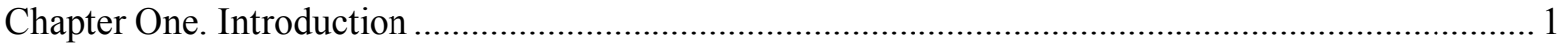

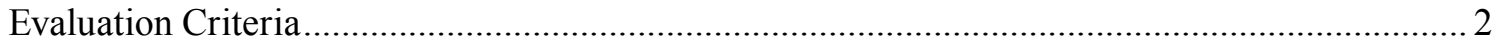

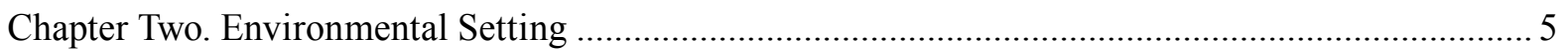

Chapter Three. Cultural History and Previous Archaeological Investigations.................................... 9

Cultural History

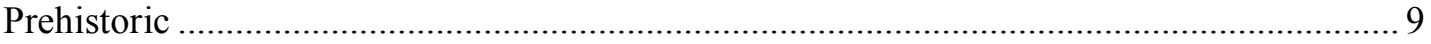

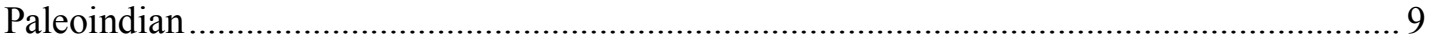

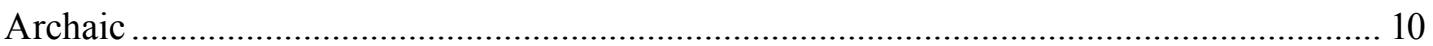

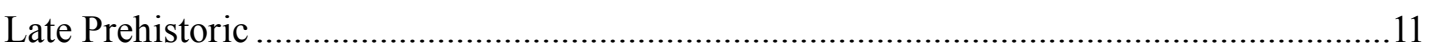

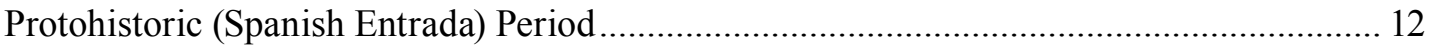

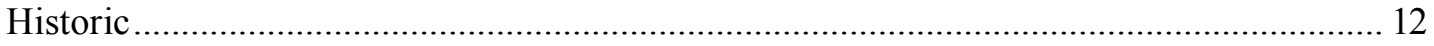

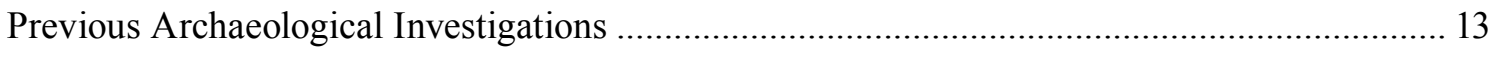

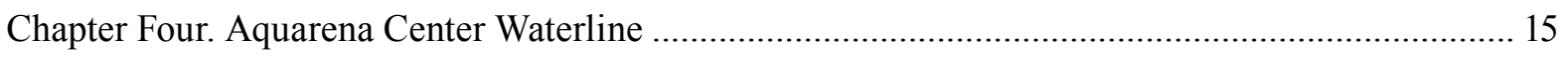

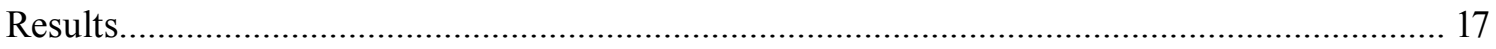

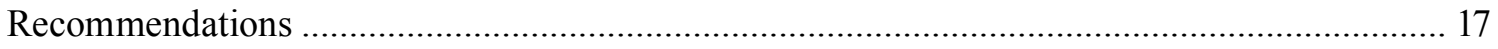

Chapter Five. Center for Research Commercialization 41HY477 ................................................... 19

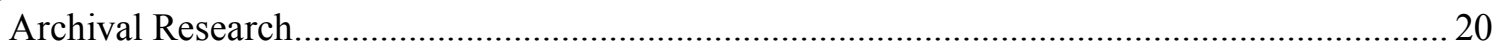

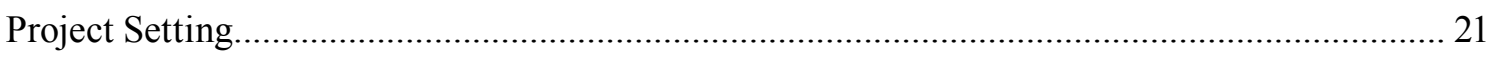

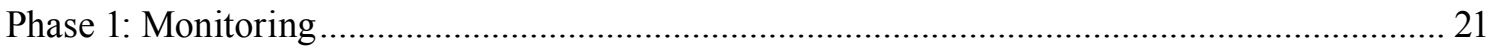

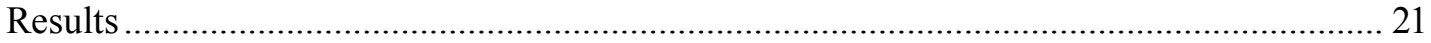

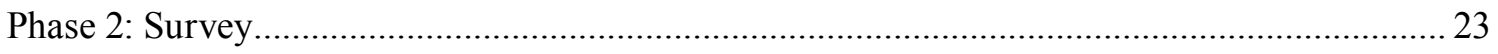

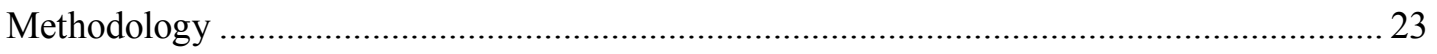

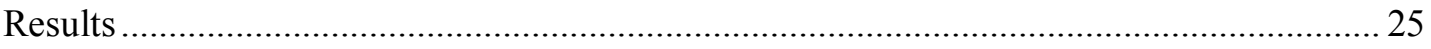

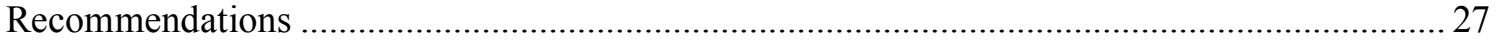

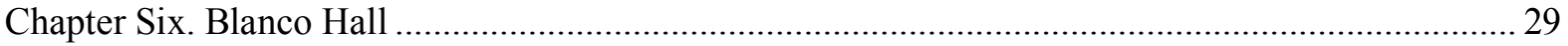

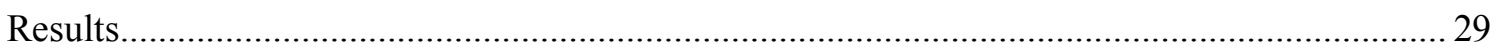

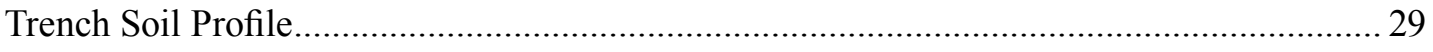

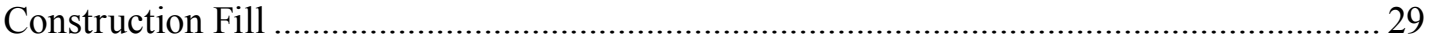

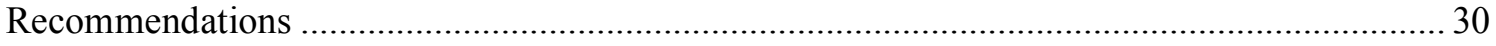

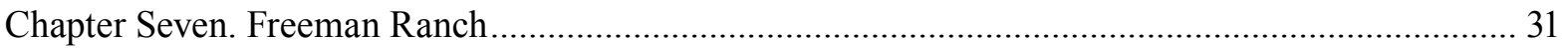

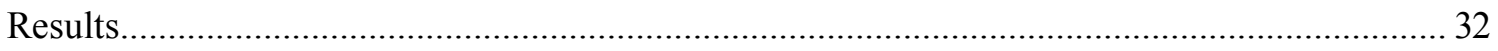

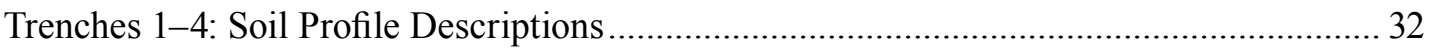

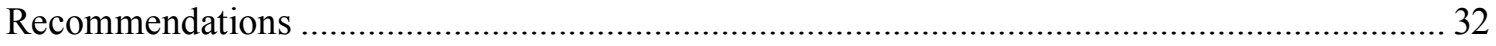




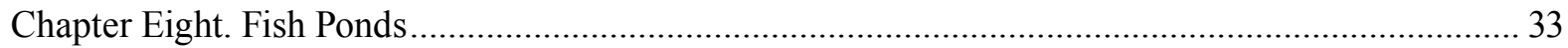

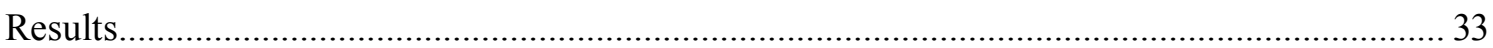

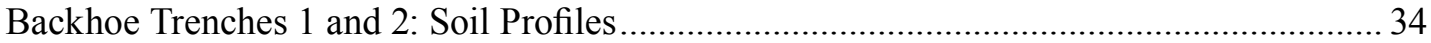

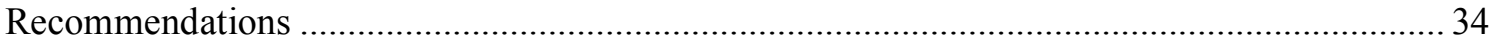

Chapter Nine. President's House Irrigation System Trenching ......................................................... 35

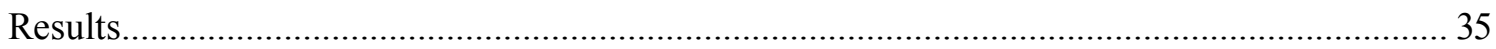

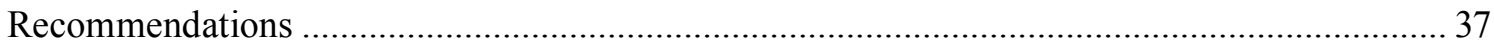

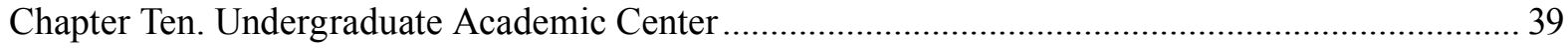

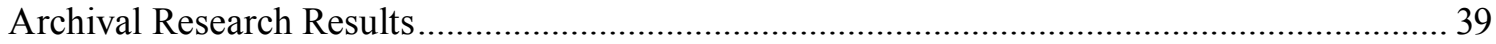

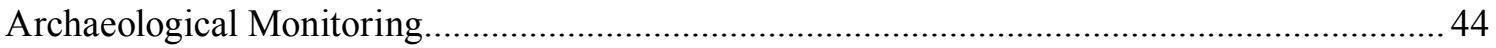

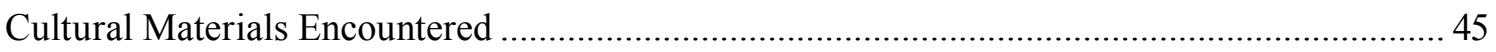

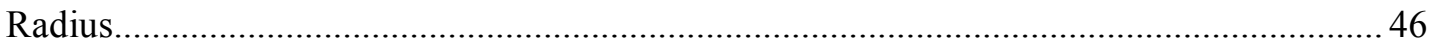

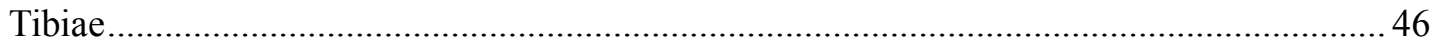

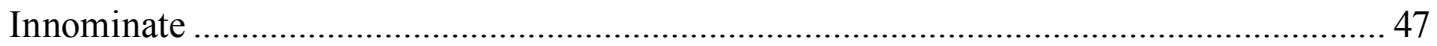

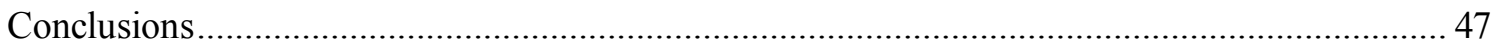

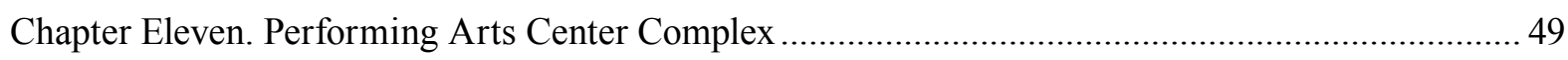

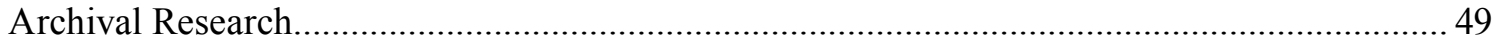

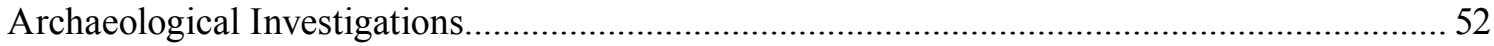

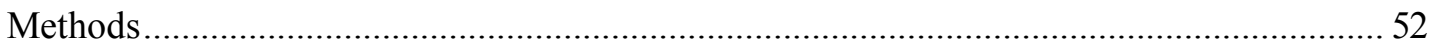

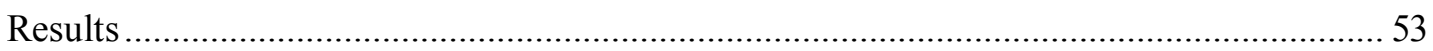

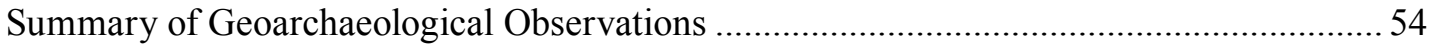

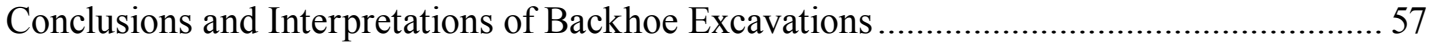

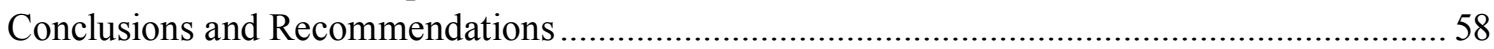

Chapter Twelve. Generator Installation at the Freeman Aquatic Biology Building Project................ 59

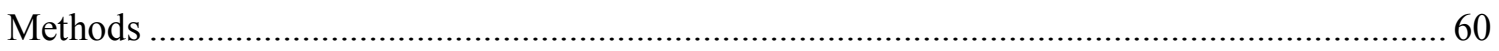

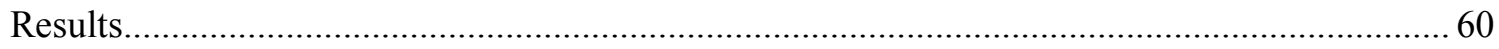

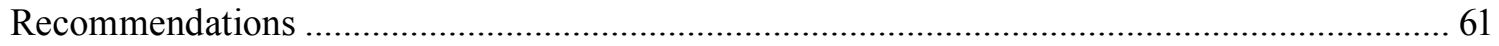

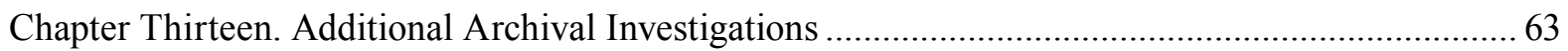

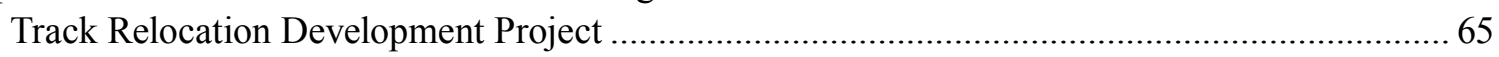

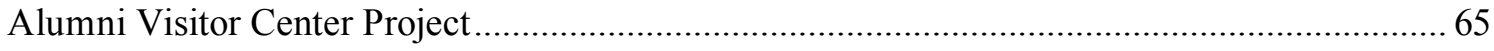

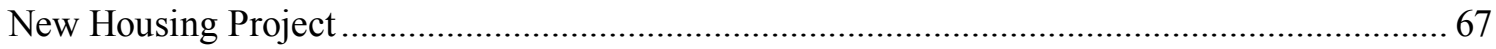

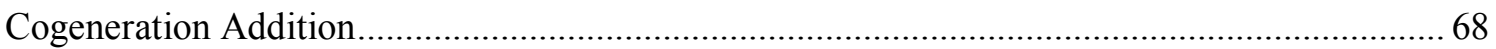

Department of Housing and Residential Life Office Building Project...................................... 68

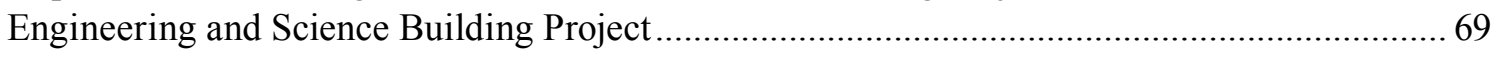

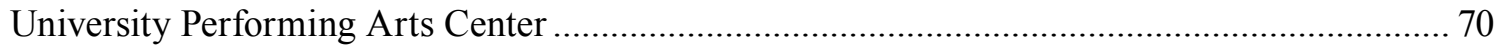

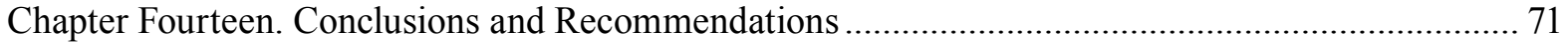

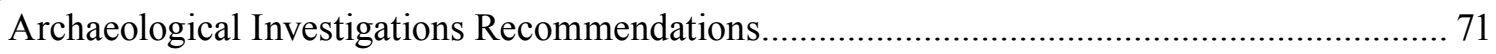

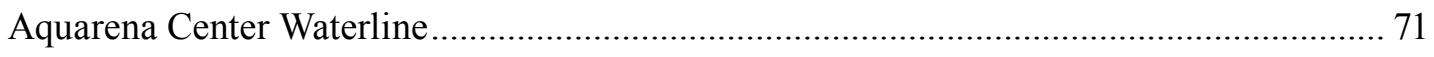

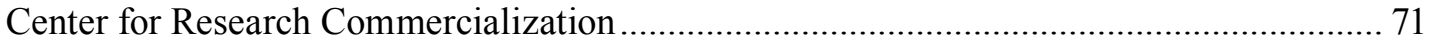

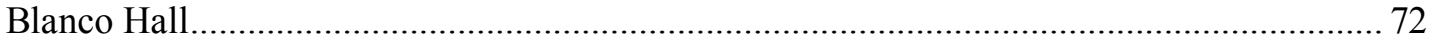

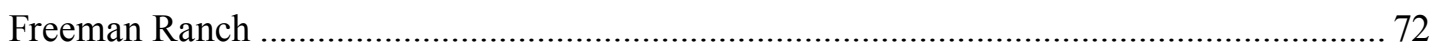

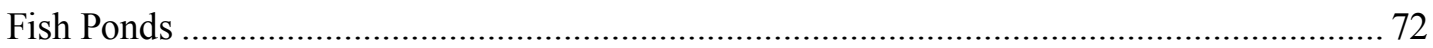

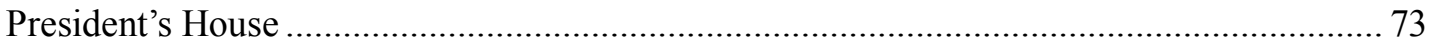

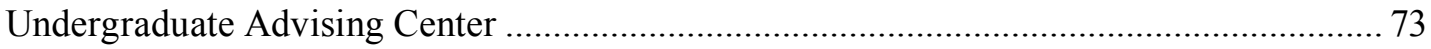




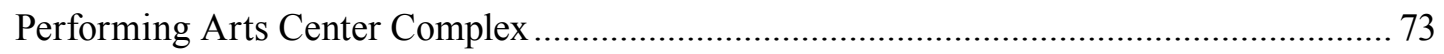

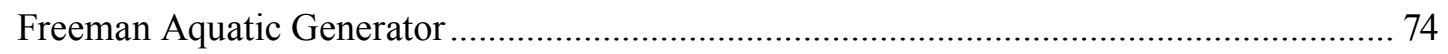

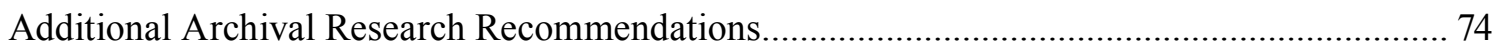

Appendix A. Center for Commercialization Project Shovel Test Excavations .................................. 87

Appendix B. Center for Commercialization Project THC Clearance Letter....................................... 93

Appendix C. Performing Arts Center Complex Backhoe Trench Technical Descriptions .................. 97

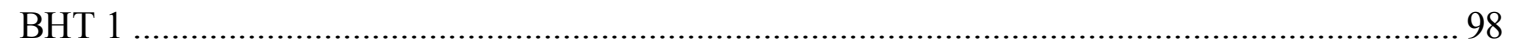

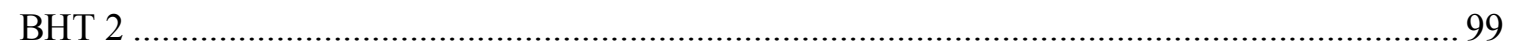

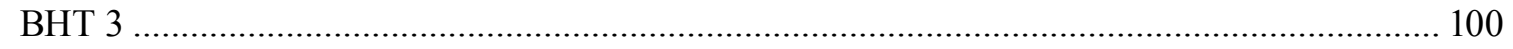

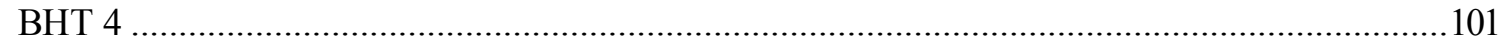

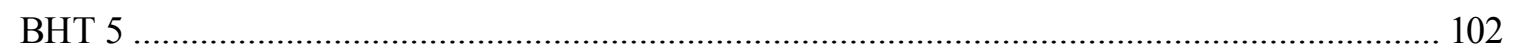

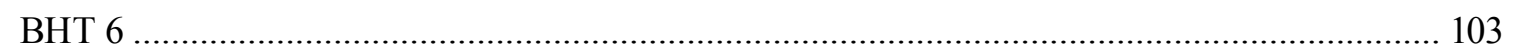

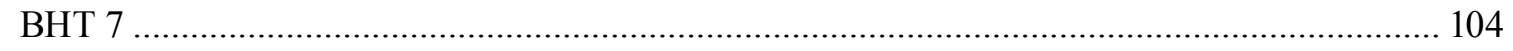

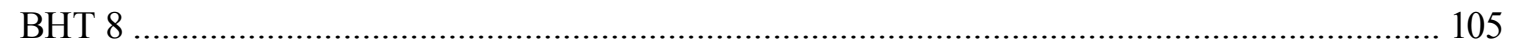

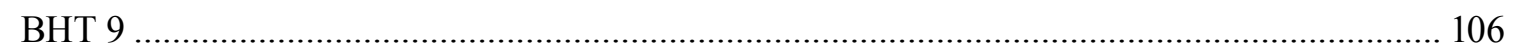

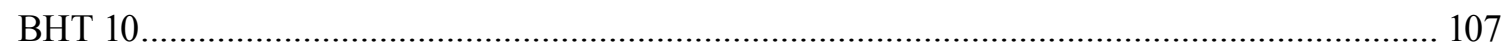

Appendix D. Performing Arts Center Complex THC Clearance Letter ......................................... 109 


\section{List OF Figures}

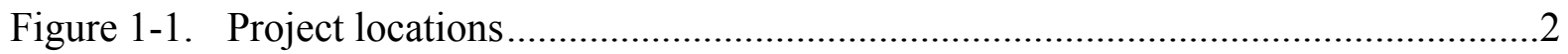

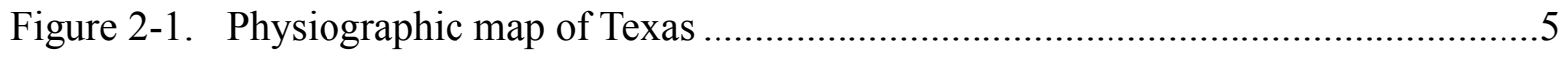

Figure 4-1. Location of Aquarean Center waterline repair (red star) ................................15

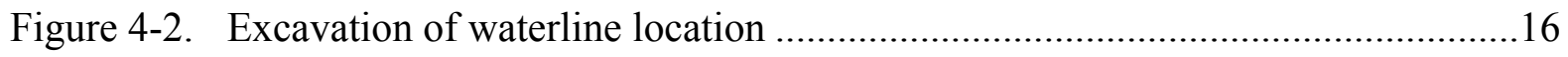

Figure 4-3. Continued excavation of waterline location ...............................................16

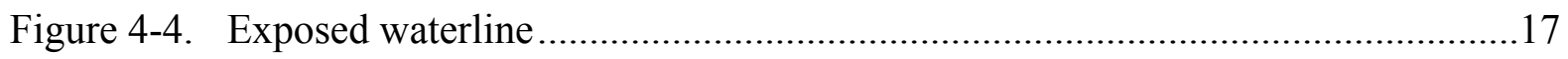

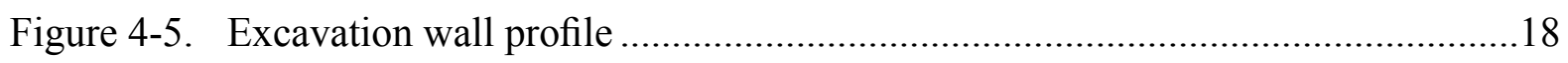

Figure 5-1. Center for Research and Commercialization project location ..........................19

Figure 5-2. Overview of Center for Research Commercialization project area; facing

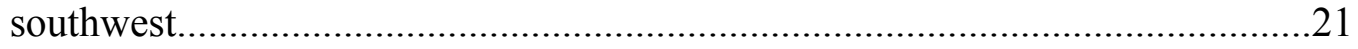

Figure 5-3. Geotechnical boring by Holt Engineering; facing north...............................21

Figure 5-4. Locations of bore holes and cultural materials ............................................22

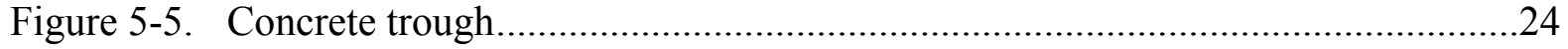

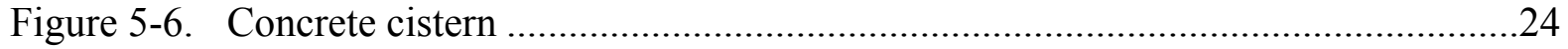

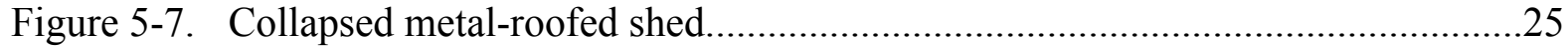

Figure 5-8. Shovel test locations, bore hole locations, and site boundary..........................26

Figure 6-1. Trench location in front of Blanco Hall ......................................................29

Figure 6-2. Blanco Hall project location (yellow star) ....................................................30

Figure 7-1. Freeman Ranch project and backhoe trench locations....................................31

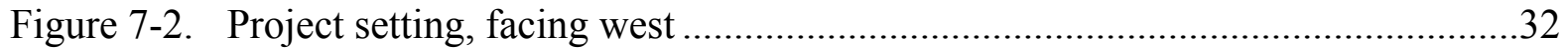

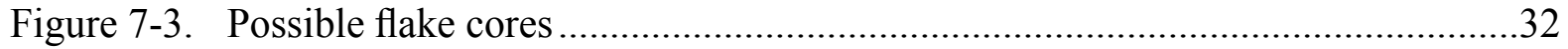

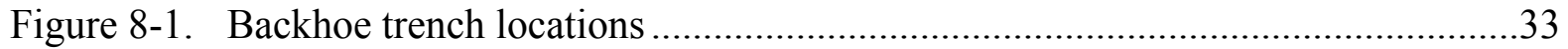

Figure 8-2. Texas State Facilities Services excavating Trench 2 .....................................34

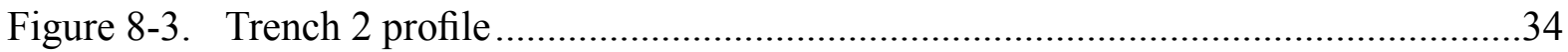

Figure 9-1. President's House irrigation trench project location.........................................35

Figure 9-2. Texas State University's Grounds and Irrigation crewmembers excavating trench adjacent to the President's House; facing southwest .............................36

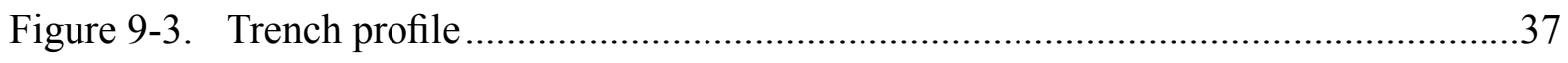

Figure 10-1. Aerial photo with approximate proposed construction boundary in red............40

Figure 10-2. 1970 Plat map of Block 2, C. C. Mitchell Addition.........................................40

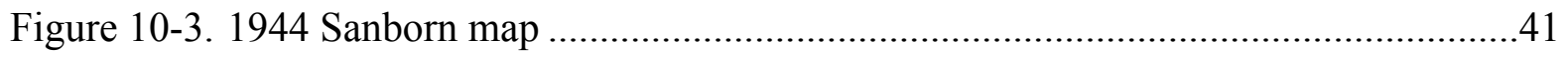

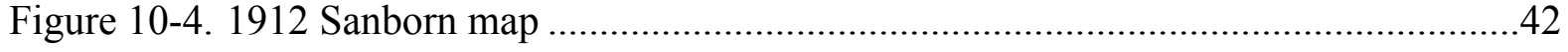




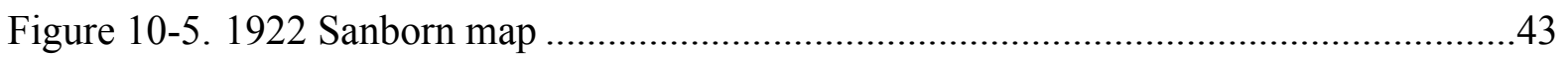

Figure 10-6. Aerial photo from 1961 Pedagog.................................................................44

Figure 10-7. Bricks recovered during monitoring ..............................................................45

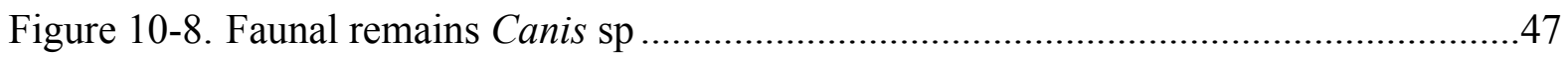

Figure 11-1. Project APE (red line) located on San Marcos North USGS quadrangle map

Figure 11-2. Performing Arts Complex APE within red lined area.....................................50

Figure 11-3. Overview of project location with proposed improvements ............................51

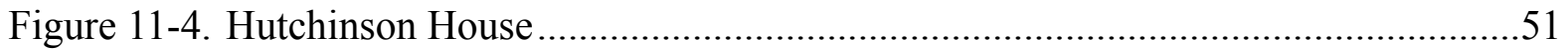

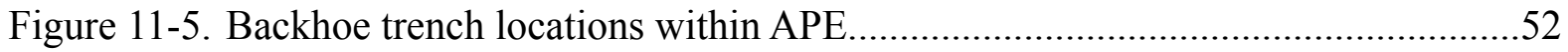

Figure 11-6. Archaeologist David Yelacic completing a trench wall profile.........................53

Figure 11-7. Nolan-like projectile point recovered from BHT 10; dorsal and ventral

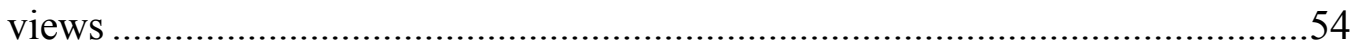

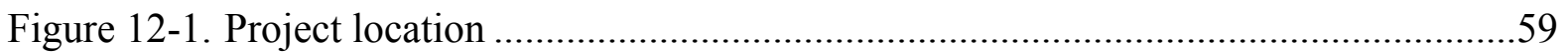

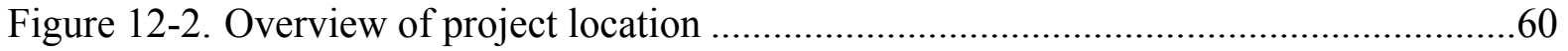

Figure 12-3. Location of shovel tests within project area .............................................61

Figure 13-1. Campus map with locations of archival research properties ...........................64 


\section{List OF TABLES}

Table 3-1. Previously Investigated Sites in the Texas State University Vicinity ................14

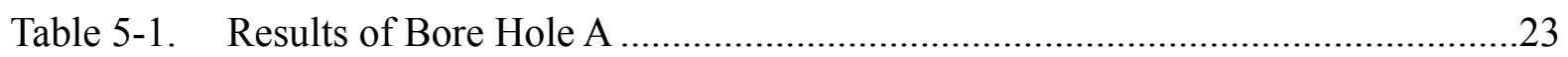

Table 5-2. Results of Bore Hole B .............................................................................23

Table 5-3. Results of Bore Hole F..........................................................................23

Table 10-1. Artifacts Recovered from Areas B, C, and D (see Figure 10-1) ......................46

Table 11-1. Inventory of Artifacts Collected from all Backhoe Trenches ..........................54

Table 11-2. Radiocarbon Dates from Humate Samples 1 and 2 ......................................55

Table 13-1. Past Owners of Parcels or Portion of Parcels to be Developed .........................69

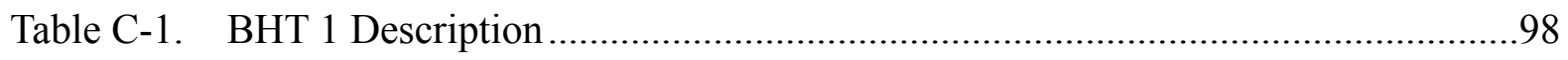

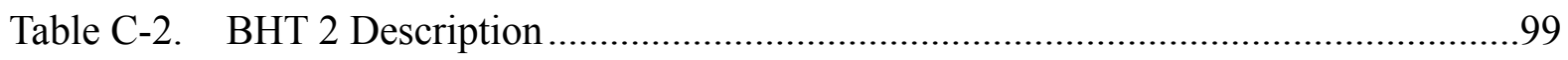

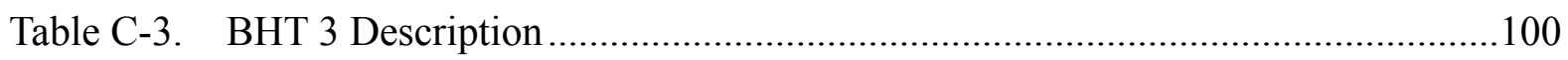

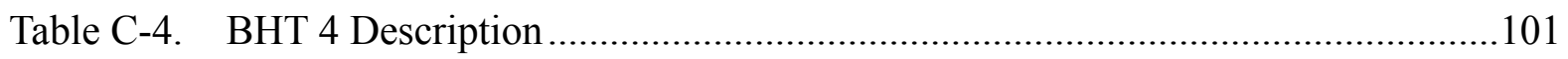

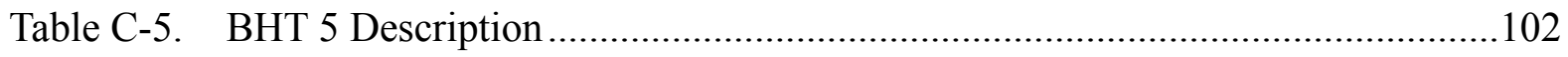

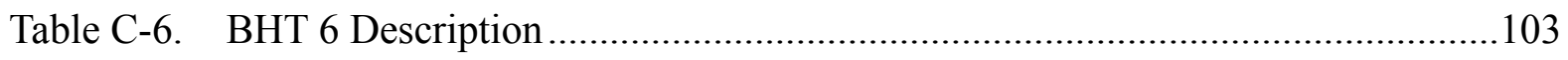

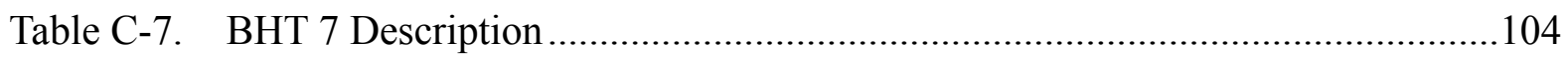

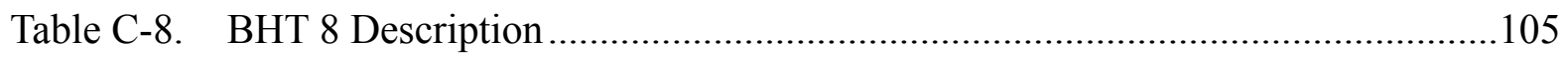

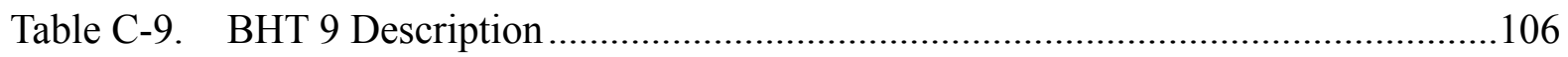

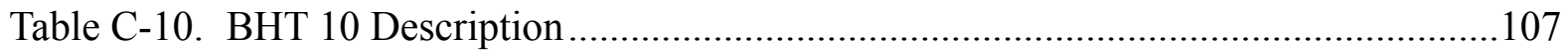




\section{AcKnowledgments}

The Center for Archaeological Studies at Texas State University-San Marcos would like to acknowledge the assistance and support of Nancy K. Nusbaum, Associate VP, Planning, Finance and Support Services, Juan Guerra, Associate VP, Facilities, and CJ Hall, Construction Contract Administrator. Their commitment to protecting and preserving the cultural resources of Texas State University-San Marcos are greatly appreciated! Thanks also goes to the staff at Facilities for their assistance on many occasions.

These projects would not have been completed without the hard work and help of CAS staff archaeologists Antonio Padilla, David Yelacic, and Julian A. Sitters. Additional assistance was provided by CAS staff members Sarah Scogin, Veronica Suarez, Amy Benton, Cinda Timperley, and Director Dr. Jon C. Lohse. Maggie McClain assisted with the technical editing and formatting of this report. I would also like to thank Kris Toma of the University Archives. Archival research for these projects was greatly enhanced by her hard work. 


\section{Chapter One}

\section{INTRODUCTION}

By Carole A. Leezer and Jon C. Lohse

The following report describes cultural resource management projects conducted by the Center for Archaeological Studies (CAS) at Texas State University-San Marcos on behalf of Texas State University-San Marcos (University) during the year 2010 under Texas Antiquities Permit No. 5509. As an institution of higher education receiving funds from the State of Texas, the University is obligated under the Texas Antiquities Code to consider the impact of its development activities on potentially important cultural (historic and prehistoric) resources that may be present in those project areas. Under a Memorandum of Agreement (MOA) between the Texas Historical Commission (THC) and the University, CAS is authorized to assist in determining whether proposed University undertakings have the potential to negatively impact cultural resources, and if so, to recommend to the University courses of future action that may avoid or offset that impact; these evaluations and Phase 1-level site assessments are conducted under Texas Antiquities Permit No. 5509, issued by the THC to CAS for 2010 .

CAS conducted nine cultural resource investigations on behalf of the University during 2010. Projects included: the monitoring of the excavation of a waterline at the Aquarena Center; archaeological monitoring, intensive archaeological survey, and associated archival background research of the proposed location of the University's Center for Research Commercialization; archaeological monitoring of a trench excavation adjacent to Blanco Hall; archaeological monitoring of four trenches measuring 3 meters $(\mathrm{m})$ deep by $1.4 \mathrm{~m}$ wide at Freeman Ranch; archaeological monitoring of a waterline repair at the University Fish Ponds; archaeological monitoring of an irrigation line adjacent to the President's House; archival research and archaeological monitoring associated with construction of the Undergraduate Academic Center; archival research and intensive archaeological survey associated with construction of the Performing Arts Center; and intensive archaeological survey conducted in advance of construction of the Freeman Aquatic Generator station. These projects were located on either the central campus of the University or on properties owned by the University (Figure 1-1).

In addition to the archival research conducted in advance of the above-listed projects, further archival research was completed outside of and separate from the scope of the MOA. This research was conducted to gather preliminary data that could be used to inform proposed construction/ development of seven properties identified for remodeling in the University's Campus Master Plan 2006-2015. Properties include the location of the proposed Alumni Visitor Center, Cogeneration Addition, Engineering and Science Building, Housing and Residential Life Office Building, New Housing Project, Track Relocation, and the University Performing Arts Center. Any buildings or site locations determined to have the potential to possess historical and/or 


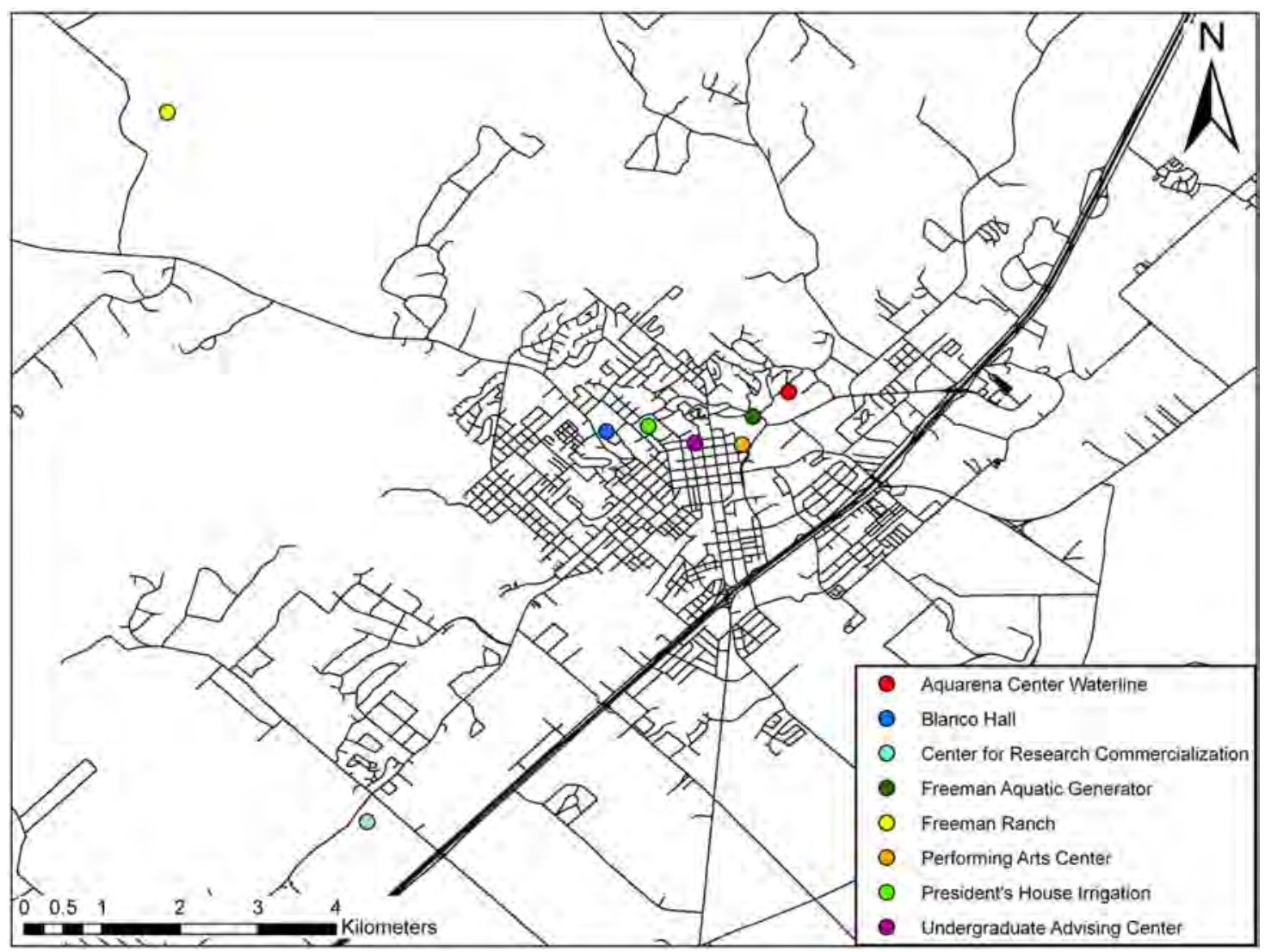

Figure 1-1. Project locations.

archaeological significance will be coordinated separately with the THC. Summaries of these separate archival research investigations are also presented in this report.

The purposes of the above-listed archaeological and archival investigations were 1) to identify cultural resources that could potentially be impacted by the proposed construction/development projects; and 2) to make recommendations on identified cultural resources as to eligibility for designation as a State Archeological Landmark (SAL) and for nomination for listing to the National Register of Historic Places (NRHP).

\section{Evaluation Criteria}

There are two main cultural properties categories (historic structures and archaeological sites) that are utilized in the evaluation of sites for SAL designations. The evaluation criteria are found in Chapter 26 Rules and Procedures for administering the Antiquities Code of Texas.

Historic structures may be recommended for designation as SALs following the criteria in Section 26.7, Criteria for Evaluating Historic Structures, provided that the following conditions are met:

(1) the structure, or building is listed in the National Register of Historic Places; and

(2) the structure, or building fits within at least one of the following criteria:

(A) is associated with events that have made a significant contribution to the broad patterns of our history; 
(B) is associated with the lives of persons significant in our past;

(C) is important to a particular cultural or ethnic group;

(D) is the work of a significant architect, master builder, or craftsman;

(E) embodies the distinctive characteristics of a type, period, or method of construction, possesses high aesthetic value, or represents a significant and distinguishable entity whose components may lack individual distinctions;

(F) has yielded or may be likely to yield information important to the understanding of Texas culture or history.

In Section 26.8, Criteria for Evaluating Archeological Sites, the THC uses the following criteria when assessing the appropriateness of official landmark designation, and/or the need for further investigations under the permit process:

(1) the site has the potential to contribute to a better understanding of the prehistory and/ or history of Texas by the addition of new and important information;

(2) the site's archaeological deposits and the artifacts within the site are preserved and intact, thereby supporting the research potential or preservation interests of the site;

(3) the site possesses unique or rare attributes concerning Texas prehistory and/or history;

(4) the study of the site offers the opportunity to test theories and methods of preservation, thereby contributing to new scientific knowledge;

(5) the high likelihood that vandalism and relic collecting has occurred or could occur, and official landmark designation is needed to insure maximum legal protection, or alternatively further investigations are needed to mitigate the effects of vandalism and relic collecting when the site cannot be protected.

Properties listed or potentially eligible for listing on the NRHP fall under the jurisdiction of Section 106 of the National Historic Preservation Act of 1966. The criteria for nominating properties and determining NRHP eligibility is contained in 36CFR60 (United States Congress 2004). The NRHP evaluation criteria attempt to address the historical significance of a wide variety of properties, both historical and archaeological, including places, structures, and objects as stated in 36CFR60.4:

The quality of significance in American history, architecture, archeology, engineering, and culture is present in districts, sites, buildings, structures, and objects that possess integrity of location, design, setting, materials, workmanship, feeling, and association and

(A) that are associated with events that have made a significant contribution to the broad patterns of our history; or

(B) that are associated with the lives of persons significant in our past; or

(C) that embody the distinctive characteristics of a type, period, or method of construction, or that represent the work of a master, or that possess high artistic values, or that represent a significant and distinguishable entity whose components may lack individual distinction; or

(D) that have yielded, or may be likely to yield, information important in prehistory or history. 


\section{Chapter Two}

\section{Environmental Setting}

\section{By Carole A. Leezer}

The main campus of the University and the location of the majority of the cultural resources investigations conducted under Texas Antiquities Permit No. 5509 are located within the City of San Marcos. San Marcos is located in Hays County, in southeastern Central Texas. The area is characterized as an ecotonal zone (a transition area between two adjoining large-scale environmental provinces) capable of supporting a tremendous diversity of fauna and flora (Crumley 1994). The city lies on the boundary between the Edwards Plateau (Hill Country) and the Blackland Prairie (Figure 2-1). The San Marcos River and the San Marcos Springs (dammed in 1849 to form Spring Lake), located at the base of the Balcones Escarpment, mark the boundary between these areas. The San Marcos Springs have attracted human populations for over 11,500 years and were known to the Tonkawa Indians as Canocanayesatetlo, to early European settlers as St. Mark's, and today as Aquarena Springs (Brune 2005). They are the second largest springs in Texas, support a tremendous amount of wildlife, and served as an important stop on the El Camino Real and the Chisholm cattle trail. The springs serve as the headwaters of the San
Marcos River, which has provided power to gin, corn, saw, and grist mills, and an ice factory in recent history.

The Edwards Plateau was formed 10-20 million years ago during the Miocene period, during which tremendous tectonic activity uplifted regions north and west of the Balcones fault 2000 feet (ft) in elevation (Spearing 1991:113). Numerous natural springs arose in areas where the Balcones Escarpment had perforated underground aquifers. Since the Late Pleistocene, erosion off of the Edwards Plateau

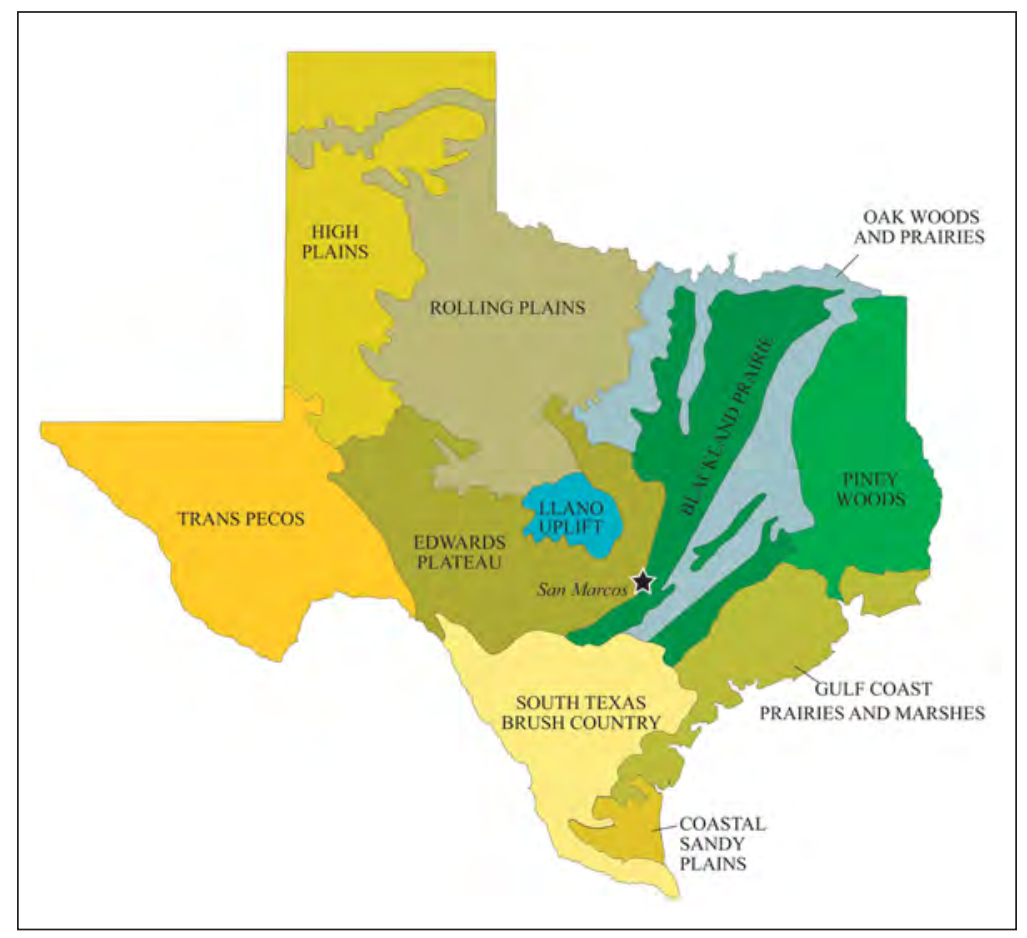

Figure 2-1. Physiographic map of Texas. 
stripped sediments and deposited them below the Balcones Escarpment to form deep Late Pleistocene Holocene fills that are both dark and rich in nutrient content. Areas in which dark deposits accumulated below the Edwards Plateau are geographically known as the Blackland Prairie physiographic province (Black 1989). Since the Balcones Escarpment runs through the northern portion of San Marcos, the northern portion of San Marcos falls within the elevated Edwards Plateau, while the central and southern portion of San Marcos falls within the Blackland Prairie physiographic province.

The Edwards Plateau is characterized by hot summers and fairly warm winters. The average winter temperature is $52^{\circ} \mathrm{F}$ and the average temperature in the summer is $84^{\circ} \mathrm{F}$. The total annual precipitation for this area is 33 inches, with 57 percent occurring between the months of April and September (Batte 1984:3). The Edwards Plateau falls under the Juniper-OakMesquite Savanna vegetative region (Black 1989) and the Edwards Plateau vegetative region as defined by Gould (1962). Typical flora which characterize this upland setting include: Texas oak (Quercus buckleyi), cedar elm (Ulmus crassifolia), mesquite (Prosopis juliflora), ash juniper (Juniperus ashei), buffalo grass (Buchloe dactyloides), grammas (Bouteloua spp.), prickly pear (Opuntia lindheimeri), various mosses, and greenbrier (Smilax bona-nox). Early pioneering settlers to the Edwards Plateau described the area as vast grasslands in which numerous large cedars (ash juniper) grew on hill and mountain peaks (Tomka and Leffler 1998:32-33). After the colonization of the Edwards Plateau, cedars that were originally confined to hilltops (where they were not destroyed by natural fires) began to migrate down into the valleys. Cedar is now commonly seen in all areas of the Edwards Plateau region. Over-grazing by cattle resulted in an increase in invader species (e.g., mesquite and buffalo grass) that rapidly displaced indigenous flora species (Ellis et al. 1995) following the settlement and development of ranching on the Edwards Plateau during the mid-nineteenth century. Over-grazing by cattle is the main reason behind the drastic reduction of indigenous flora on the Edwards Plateau.

Fauna noted in the Edwards Plateau region fall within the Balconian Biotic Province as described by Blair (1950). The Balconian Biotic Province corresponds with the Edwards Plateau physiographic region. Typical fauna observed within this province include: raccoon, nine banded armadillo, opossum, fox, squirrel, skunk, and white-tailed deer.

The Blackland Prairie vegetative region is characterized by deep, dark clay soils that have been accumulating since the end of the Miocene (Black 1989). The deep soil deposits of the Blackland Prairie support numerous tall-mid grasses such as grammas (Bouteloua spp.) and bluestem (Schizachyrium scoparium frequens), which are the natural vegetative species for this environment (Ellis et al. 1995). In addition, mesquite (Prosopis glandulosa), pecan (Carya illinoinensis), hackberry (Celtis laevigata), junipers (Juniperus ashei), and live oak (Quercus virginiana) are often observed in the low flat woodlands along streams located within the Blackland Prairie. Since the mid-nineteenth century, human land modifications along with ranching/grazing activities have resulted in a dramatic increase in invader flora species (e.g., mesquite, blackjack oak, buffalo grass, and post oak) (Ellis et al. 1995). Today, only isolated patches of intact Blackland Prairies, unaffected by human activities, survive in the Oak Woods and Prairies region to the east. This portion of the Blackland Prairie is located in the transitional 
zone between the Balconian and Tamaulipan biotic provinces (Blair 1950). Therefore, the area is likely to have species from both of these provinces utilizing the natural resources.

Typical fauna associated with this region include: white-tailed deer (Odocoileus virginianus), badger (Taxidea taxus), eastern cottontail (Sylvilagus floridanus), raccoon (Procyon lotor), and opossum (Didelphus virginiana). In prehistoric times, large numbers of bison (Bison bison) were commonly observed in the Blackland Prairie environment. 


\section{Chapter Three}

\section{Cultural History and Previous Archaeological Investigations}

By Carole A. Leezer

\section{Cultural History}

Human presence in the region is divided into three periods: Prehistoric (including Paleoindian, Archaic, and Late Prehistoric), Protohistoric, and Historic. Evidence for prehistoric occupation in and around the San Marcos area extends from the Clovis period, approximately 11,500 radiocarbon years ago up until the arrival of Spanish explorers almost 400 years ago. Historic documents record the use of the San Marcos springs by Spanish and Native American groups in the seventeenth, eighteenth, and nineteenth centuries, and as early as the mid-nineteenth century by Anglo settlers such as General Edward Burleson.

\section{Prehistoric}

San Marcos lies in a transitional zone in terms of cultural influences, with traits present from Central Texas, South Texas, and, to a lesser degree, the Upper Coast of Texas (Goode 1989). Patterson (1995) has synthesized the chronological evidence for Southeast Texas, including the Upper Coastal Region. The cultural chronologies for Central and South Texas are not completely understood, but recent syntheses are presented by Black (1995), Hester (1995, 2004), and Collins (1995, 2004). Dates for prehistoric periods and parts of the Protohistoric that are derived from archaeological contexts are presented in radiocarbon years before present (BP; i.e., before 1950). Dates in the historic period are based on written accounts and are given in calendar ages.

\section{Paleoindian}

The Paleoindian stage marks the earliest human occupation of North America and extends until approximately 8000 BP. According to Hester (1995:433-436, 2004), the Paleoindian period occurred between 11,200 and 7950 BP in South Texas. Collins (1995:381-385, 2004) dates it to $11,500-8800$ BP in Central Texas. Diagnostic Paleoindian artifacts include Clovis, Folsom, and a variety of later types (Bousman et al. 2004). Early Paleoindian peoples are thought of as highly nomadic cultures that relied heavily on hunting large game animals such as mammoth, mastodon, bison, camel, and horse (Black 1989). Of these, all but bison were extinct by the end of Clovis times. Research has shown that Paleoindians utilized a wide variety of plants and animals, such as raccoons, badgers, mice, alligators, turtles, and tortoises (Black 1989; Bousman et al. 2004; Collins and Brown 2000; Hester 1983; Lemke and Timperley 2008).

A large distribution of Clovis points across North and Central America suggests a wide dispersal of their makers (Wenke 1990:201). These points are lanceolate in shape, with a thinned base resulting from "fluting," or the removal of one or more channel flakes, and are often found associated with remains of large, now-extinct herbivores. Site types include open camp sites, quarries, and caches, though kill sites are the best known. Other artifacts associated with Clovis are specialized bifaces, prismatic 
blades and blade cores, engraved stones, bone points, stone bolas, ochre, and shaft straighteners.

Clovis is followed by Folsom and Midlandstyle points; these latter types overlap slightly (Holliday 1997). Folsom points are fluted and are found in association with ancient bison remains, while Midland points are manufactured through pressure collateral flaking, but lack fluted channels. Very thin bifaces called ultrathin bifaces are also found at some Folsom sites (Stanford and Broilo 1981). Folsom peoples are considered to be specialized bison hunters. Most Folsom sites occur as surface scatters, although deeply buried deposits have been uncovered. Artifacts associated with this interval are common throughout Texas (Bousman et al. 2004).

Archaeological evidence suggests that, with the exception of bison, large game animals were extinct in Texas after 10,000 BP. Hunters instead concentrated on deer, antelope, and other game (Bousman et al. 2002, 2004). Between 10,000 and $8000 \mathrm{BP}$, Central Texas is characterized by a series of cultural groups based on changing projectile point styles that transform from stemmed to lanceolate, and then back to stemmed. Changes in the subsistence base eventually required technological shifts that mark the beginning of a new cultural period known as the Archaic.

\section{Archaic}

Collins $(1995,2004)$ dates the Archaic in Central Texas from approximately 8800 to 1200/1300 BP (other archaeologists suggest that the Archaic began at 8000 BP). Following Weir (1976), this period is divided into Early, Middle, and Late Archaic. The Archaic marks several important transitions: a shift from large game hunting to hunting smaller animals; an apparent increase in the use of plant food resources and the use of ground stone in food processing; implementation of stone cooking technology; increased use of organic materials in tool technologies and an increase in the number and variety of lithic tools for wood working; greater population stability and less residential mobility; and systematic burial of the dead. This stage is also distinguished by environmental and climatic changes and oscillations.

At the beginning of the Holocene, a significant climate change associated with the extinction of megafauna stimulated a behavioral change in land use. Groups focused more intensively on the exploitation of local resources such as deer, fish, and plant bulbs. This dietary adjustment is evidenced by the increased number of ground stone artifacts, burned rock middens, and tools such as Clear Fork gouges and Guadalupe bifaces (Turner and Hester 1993:246-256). Early Archaic sites are thinly dispersed and are seen across a wide area of Texas and northern Mexico (Weir 1976). Hester (1995:436-438; 2004) dates the Early Archaic, characterized by Early Basal Notched and Early Corner Notched dart points, to 7950-4450 BP, while Collins (1995:383, 2004) argues that the Early Archaic spans from 8800 to $6000 \mathrm{BP}$ based on three divisions of projectile point types.

The Middle Archaic in Central Texas dates from 6000 to 4000 BP (Collins 1995, 2004). Collins divides the Middle Archaic into three projectile point style intervals: Bell-AndiceCalf Creek; Taylor; and Nolan and Travis. The beginning of the Middle Archaic (Bell-AndiceCalf Creek) was a mesic period when grasslands expanded southwards into Central and South Texas; this expanding habitat attracted bison herds from the Plains. People associated with Bell-Andice-Calf Creek styles were specialized bison hunters and who maintained a toolkit specifically adapted to killing and processing bison. Points were extremely thin and broad, 
and made differently from the preceding period. The Middle Archaic in general is associated with the Altithermal, a prolonged period of warmer temperatures and increasing aridity. As the Altithermal progressed through the Middle Archaic, conditions in South and Central Texas became ever warmer and drier, and both bison and bison hunters may have retreated northwards. Taylor bifaces were manufactured during this period; these bifaces are similar to the earlier Bell-Andice-Calf Creek point styles, but lack the deep basal notches that characterize the earlier types. By the latter part of the Middle Archaic, Nolan and Travis points predominate; both are technologically and stylistically dissimilar to the preceding styles (Collins 1995, 2004). The Nolan-Travis interval was also a period when temperature and aridity were at their peaks, and there is evidence of increased utilization of xerophytes such as sotol (Johnson and Goode 1994). These plants were typically baked in earth ovens, associated with middens of burned and fire-cracked rock. During drier episodes of this period, the aquifer-fed streams and resource-rich environments of Central Texas were extensively utilized (Story 1985:40; Weir 1976:125, 128).

The Late Archaic dates to approximately 4000-1300/1200 BP (Collins 1995:384, 2004). Bison herds began returning to the southern Great Plains (Dillehay 1974), again influencing subsistence. Cemeteries at sites such as Ernest Witte (Hall 1981) and Olmos Dam (Lukowski 1988) provide some evidence that populations increased and that groups were becoming territorial (Story 1985:44-45), though this pattern may have begun in South Texas by as early as ca. 6500-7000 BP (Ricklis 2005). Pottery, which often accompanies increased sedentism, territoriality, and population growth, began appearing in limited areas of the South Texas Plains during the Late Archaic (Story 1985). However, most regions remained "pre-ceramic" for another thousand years (Story 1985:45-47). Common projectile points are Ensor and Frio (Turner and Hester 1993:114,122), both of which are short, triangular points with side notches. The Frio point also has a notched base (Turner and Hester 1993:122).

\section{Late Prehistoric}

Collins $(1995,2004)$ dates the Late Prehistoric at 1300/1200-260 BP, and follows Kelley (1947) in dividing it into the Austin and Toyah phases. This stage is marked by the shift away from the dart and atlatl to the bow and arrow, and also by the incorporation of pottery in the central and northern parts of the South Texas Plains (Black 1989:32; Story 1985:45-47). Emphasis on bison hunting during the Toyah phase was a significant factor in determining settlement and mobility patterns.

The Austin phase is characterized by small arrow points, including Edwards, Scallorn, and other types, indicating a shift from the use of atlatls to bows. Burned rock middens are sometimes associated with these types (e.g., Houk and Lohse 1993). Ground and pecked stone tools for processing plant food are increasingly common, and burials from this time reveal a high proportion of arrow-wound deaths (Black 1989; Prewitt 1974), perhaps suggesting some disputes over resource availability.

The beginning of the Toyah period (750 BP) in Central Texas is marked by contractingstemmed points and flaring, barbed-shouldered points. Perdiz is the most common example (Black 1989:32; Huebner 1991:346), and this type occasionally occurs on glass in mission contexts (e.g., Lohse 1999:268). This period is also characterized by prismatic blades, blade cores, and scrapers-on-blades, all considered part of a specialized bison hunting and processing toolkit (Black and McGraw 1985; Huebner 1991; 
Ricklis 1994). The wide variety of ceramic styles and materials seen in Toyah pottery provides information on the social composition of these groups (Arnn 2005), with assemblages displaying Caddo, Texas Gulf Coast, and Jornada Mogollon influences. Johnson (1994) contends Toyah culture represents a constellation of traits shared by a limited number of groups sprawled across a very large area of Texas. Ricklis (1994) describes it as a collection of traits that moved through relatively stable regional populations. Recently, Arnn (2007) has argued that a large number of cultural groups, many of which were documented by European explorers, interacted with each other over a large area, resulting in the spread of shared styles and technologies.

\section{Protohistoric (Spanish Entrada) Period}

The Protohistoric period was marked by Spanish entradas, formal expeditions into Texas in the late seventeenth and early eighteenth centuries. Hester defines the period as "the transition period between the Prehistoric and Historic period denoting a phase for which few written records are available, and for which most evidence is derived from archaeology" (1995:449-450, 2004). This period began with the venture by the Spanish explorer Cabeza de Vaca and the Narvaez expedition in 1528 and extends to the establishment of the Mission San Antonio de Valero (the Alamo) in San Antonio, in 1718 .

When the Spanish missions were established in East Texas in the late 1600s, entradas began to travel regularly through Central Texas. These expeditions provide the first detailed observations on the original Native American inhabitants of the region. With Alonso de León's expedition of 1680, El Camino Real (the King's Road) was established from Villa Santiago de la Monclova in Mexico to East Texas. This roadway followed established Native American trade routes and trails, and became a vital link between Mission San Juan Bautista in Northern Mexico and the Spanish settlement of Los Adaes in East Texas (McGraw et al. 1991).

Spanish priests accompanying entradas provided most of the available information on indigenous cultures of early Texas. The few surviving accounts of Native groups in Texas reveal a dynamic cultural environment where numerous tribes passed through or inhabited Central Texas at different periods. Little is known about the majority of these tribes, but those documented around the San Marcos area include the Cantona, Muruam, Payaya, Sana, and Yojuane. Other tribes encountered at San Marcos included mobile hunting parties from villages in South and West Texas, such as the Catequeza, Cayanaaya, Chalome, Cibolo, and Jumano, who were heading for bison hunting grounds in the Blackland Prairies (Foster 1995:265-289; Johnson and Campbell 1992; Newcomb 1993). Later groups migrated into the region, displacing the former groups or tribes. These included the Tonkawa from Oklahoma and Lipan and Comanche from the Plains (Campbell and Campbell 1985; Dunn 1911; Newcomb 1961, 1993). Archaeological sites dated to this period typically contain a mix of both European imported goods, such as metal objects, glass beads, and chipped stone tools.

\section{Historic}

Spanish settlement in Central Texas first occurred in San Antonio with the establishment of Mission San Antonio de Valero, and the later founding of San Antonio de Béxar (Bolton 1970 [1915]; Habig 1977; de la Teja 1995). Most knowledge of this period is gained through the written records of the early Spanish missionaries. Between 1746 and 1755, three missions, San Francisco Xavier de Horcasitas, San Ildefonso, and Nuestra Señora de la Canderlaria were 
located somewhere along the San Gabriel (known at the time as the San Xavier) River in presentday Milam County. The three missions were eventually coalesced into one, the San Xavier Mission, and moved to the San Marcos River in 1755. Shortly thereafter more than 1,000 Lipan Apaches joined the missionaries. As the San Marcos site could not support such a gathering of Indians, all property from the San Xavier missions and the presidio were reassigned in 1756 to Santa Cruz de San Sabá Mission, near presentday Menard, which would serve the Apaches in their own territory (Bolton 1970[1915]). The precise location of the San Francisco Xavier Mission along the San Marcos River has not yet been determined, but Britt Bousman speculates that it may have been located on the Aquarena Center peninsula (personal communication 2004).

Besides the mission town of San Antonio, the only other Spanish settlement in the region was San Marcos de Neve, established in 1808, four miles south of present-day San Marcos. San Marcos de Neve was abandoned in 1812 as a result of constant raids by local tribes (Dobie 1932). During this time, massive depopulation occurred among Native Americans due to diseases to which indigenous people had little resistance. Those few remaining were gradually displaced to reservations beginning in the mid1850s (Fisher 1998).

Mexico achieved independence from Spain in 1827, opening settlements in what is today known as South Texas. European presence increased as settlers received land grants from the Mexican government until 1835. Settlement was difficult, however, due to raids by Native American groups. The Texas Rangers provided protection from these conflicts after Texas secured independence from Mexico in 1836. Settlement in the region increased until 1845, when Texas gained admission to the United States, resulting in the formation of Hays County in 1848 (Bousman and Nickels 2003).

\section{Previous Archaeological Investigations}

Ten archaeological sites have been recorded either on or adjacent to the University. These are 41HY37, 41HY133, 41HY135, 41HY147, 41HY160, 41HY161, 41HY165, 41HY318, 41HY319, and 41HY432. Work has been conducted off and on at some of these sites for more than 30 years (Table 3-1).

Based on the results of previous archaeological investigations within and adjacent to the University, cultural materials in good contexts are undeniably present and may be impacted by planned construction/development on University property. Components and assemblages encountered in these areas may date from the Paleoindian or Early Archaic periods through the Archaic and Late Prehistoric periods, even into the Colonial and Historical eras, and provide the greatest potential to provide highquality data sets that would contribute to a better understanding of prehistoric occupations within the San Marcos area. 
Table 3-1. Previously Investigated Sites in the Texas State University Vicinity.

\begin{tabular}{|c|c|c|c|}
\hline Site & When Investigated & Components & Citations \\
\hline $41 \mathrm{HY} 37$ & $1983,2000,2010$ & $\begin{array}{l}\text { Historic Burleson homestead; Late } \\
\text { Prehistoric and Late Archaic (Late } \\
\text { Archaic: Pedernales and Edgewood } \\
\text { points) }\end{array}$ & $\begin{array}{l}\text { Bousman and Nickels 2003; } \\
\text { Garber and Orlof 1984; } \\
\text { Yelacic and Lohse } 2010\end{array}$ \\
\hline 41HY133 & 1977 & Prehistoric open camp site, midden & Warren $1977 \mathrm{a}$ \\
\hline 41HY135 & 1977 & Prehistoric open camp site & Warren $1977 b$ \\
\hline $41 \mathrm{HY} 147$ & 1979, 1990, 1990 & $\begin{array}{l}\text { Archaic, late and early Paleoindian, } \\
\text { Pleistocene fauna }\end{array}$ & $\begin{array}{l}\text { Shiner 1983; Takac 1990, } \\
\text { 1991a, 1991b }\end{array}$ \\
\hline $41 \mathrm{HY} 160$ & $\begin{array}{l}1982,1983,1991,1997 \\
1998,2001,2002,2003 \\
2004,2006\end{array}$ & $\begin{array}{l}\text { Discrete components from Late } \\
\text { Prehistoric through Early Archaic, } \\
\text { domestic features }\end{array}$ & $\begin{array}{c}\text { Aery 2007; Nickels and } \\
\text { Bousman 2010; Garber et al. } \\
\text { 1983; Oksanen 2006; Ramsey } \\
1997\end{array}$ \\
\hline 41HY161 & $\begin{array}{c}1978,1997,1998,2000 \\
2004,2008,2009\end{array}$ & $\begin{array}{l}\text { mixed historic and Archaic, Late } \\
\text { Archaic, late and early Paleoindian, } \\
\text { human remains, Pleistocene fauna }\end{array}$ & $\begin{array}{l}\text { Garber and Glassman 1992; } \\
\text { Ford and Lyle 1998; Jones } \\
\text { 2002; Leezer et al. 2010; Lyle } \\
\text { et al. 2000; Oksanen 2008; } \\
\text { Shiner 1979, 1981, 1984; Stull } \\
\text { 2009; Yelacic et al. 2008 }\end{array}$ \\
\hline 41HY165 & $\begin{array}{l}1984,1996-1998 \\
2000-2001\end{array}$ & $\begin{array}{l}\text { Prehistoric, Middle Archaic, bison, } \\
\text { historic, mixed historic and prehistoric }\end{array}$ & $\begin{array}{l}\text { Giesecke 1998; Ringstaff } \\
\text { 2000; Soucie and Nickels } \\
\text { 2003; Soucie et al. } 2004\end{array}$ \\
\hline $41 \mathrm{HY} 318$ & 2001 & $\begin{array}{l}\text { Unidentified historic structure (ca. } \\
1890 \text { ) }\end{array}$ & Jones 2002 \\
\hline 41HY319 & 2001 & Prehistoric lithic scatter & Barrera 2002 \\
\hline 41HY432 & 2007 & unknown prehistoric & King 2007 \\
\hline
\end{tabular}




\section{Chapter Four}

\section{Aquarena Center Waterline}

By Julian A. Sitters and David Yelacic

On January 14, 2010, CAS archaeologists Julian A. Sitters and David Yelacic monitored the repairs to a waterline just north of the Aquarena Spring's Gift Shop (Figure 4-1). This area lies close to the center of SAL 41HY160. A breach of the waterline prompted the expedited excavation of a $50 \times 50$-centimeter $(\mathrm{cm})$ area to a depth of approximately $66 \mathrm{~cm}$ to address issues with the corroded waterline (Figures 4-2 and 4-3). While the waterline in question was considered a "dead line," it was connected to conduits that supply water to the infrastructure at the Aquarena Center. The exposed waterline line lay approximately $35 \mathrm{~cm}$ below the ground surface (Figure 4-4).

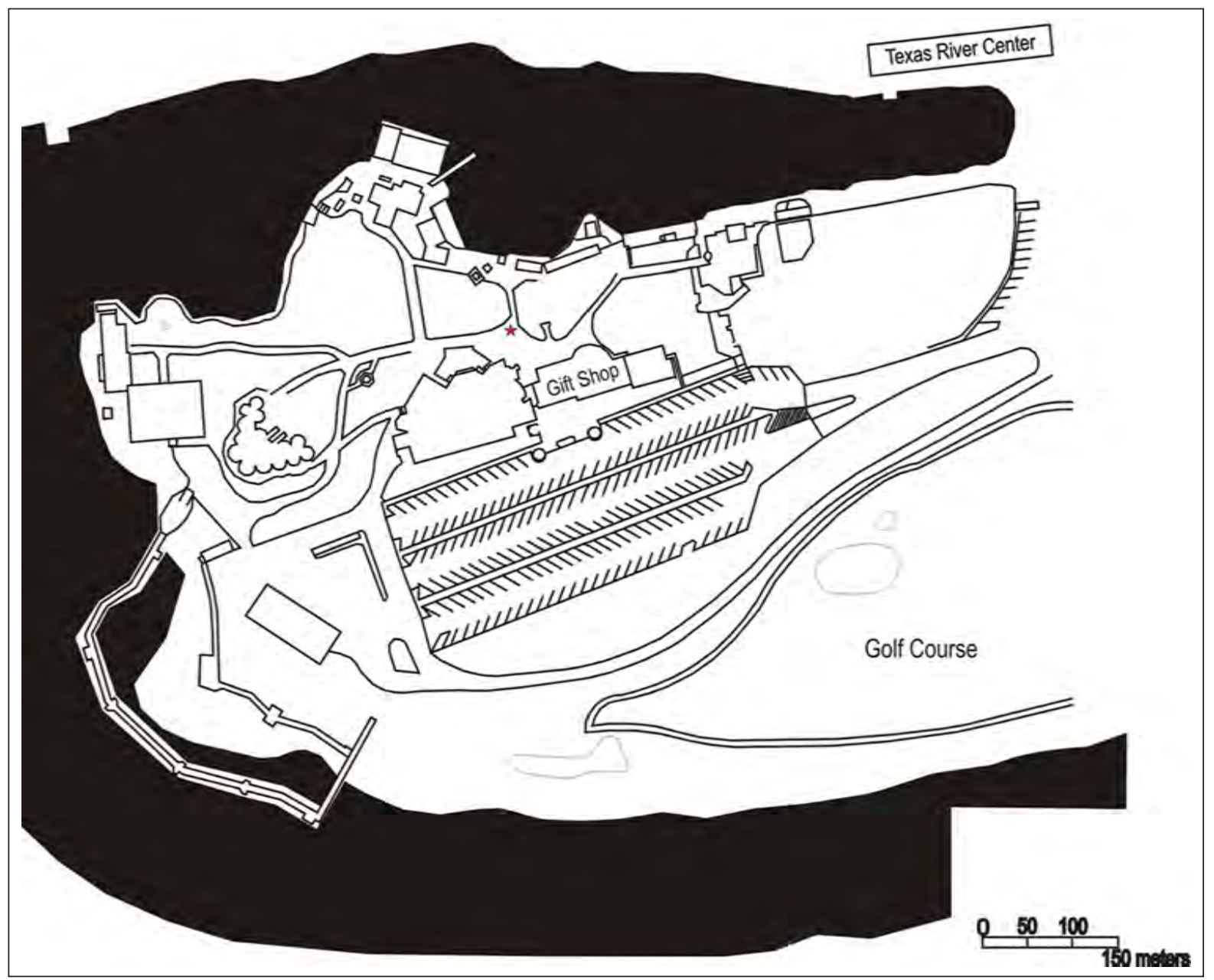

Figure 4-1. Location of Aquarean Center waterline repair (red star). 


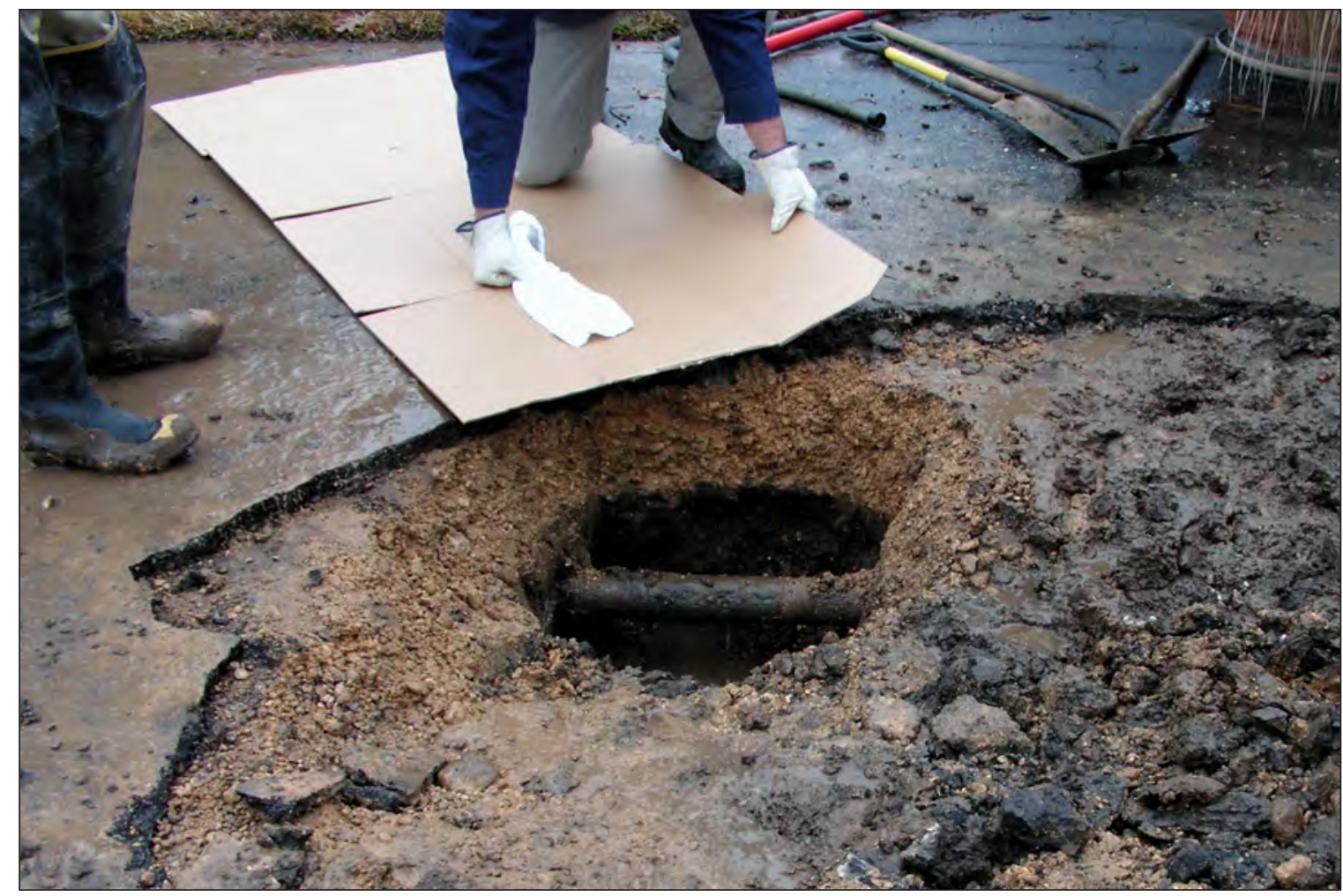

Figure 4-2. Excavation of waterline location.

Archaeologists observed the excavation of sediment adjacent to the conduit. The observed sediment was devoid of any cultural material. A schematic profile (Figure 4-5) was drawn, and it appeared that the sediment encountered had been previously disturbed, probably by the initial construction of the plumbing infrastructure. The waterline was quickly repaired, and no additional excavations were conducted.

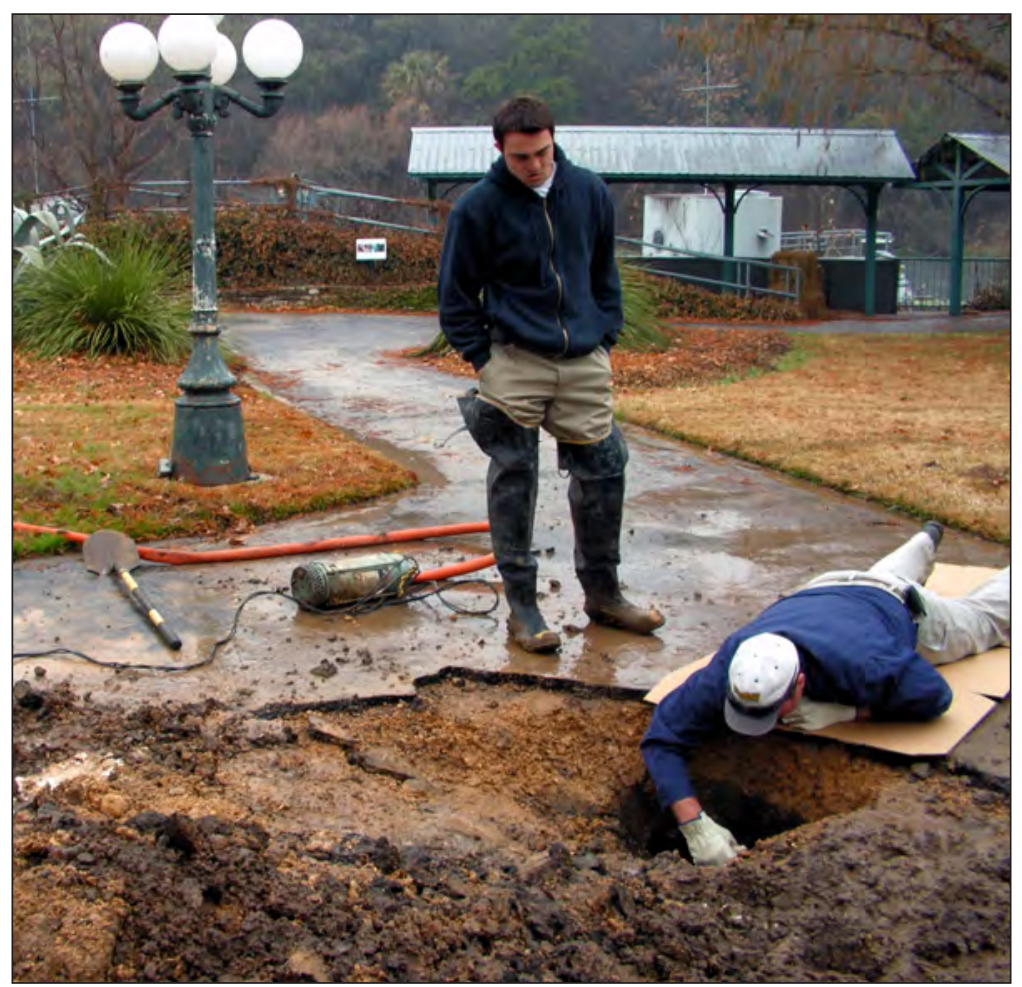

Figure 4-3. Continued excavation of waterline location. 


\section{Results}

No cultural materials were observed in the excavation pit or in the spoil pile. The top $30 \mathrm{~cm}$ of the profile consisted of construction fill. Below the construction fill, $30-65 \mathrm{~cm}$, the soil was black clay (7.5YR 1.5/1; see Figure 4-4).

\section{Recommendations}

As no cultural materials were observed, no additional archaeological investigations were warranted or recommended.

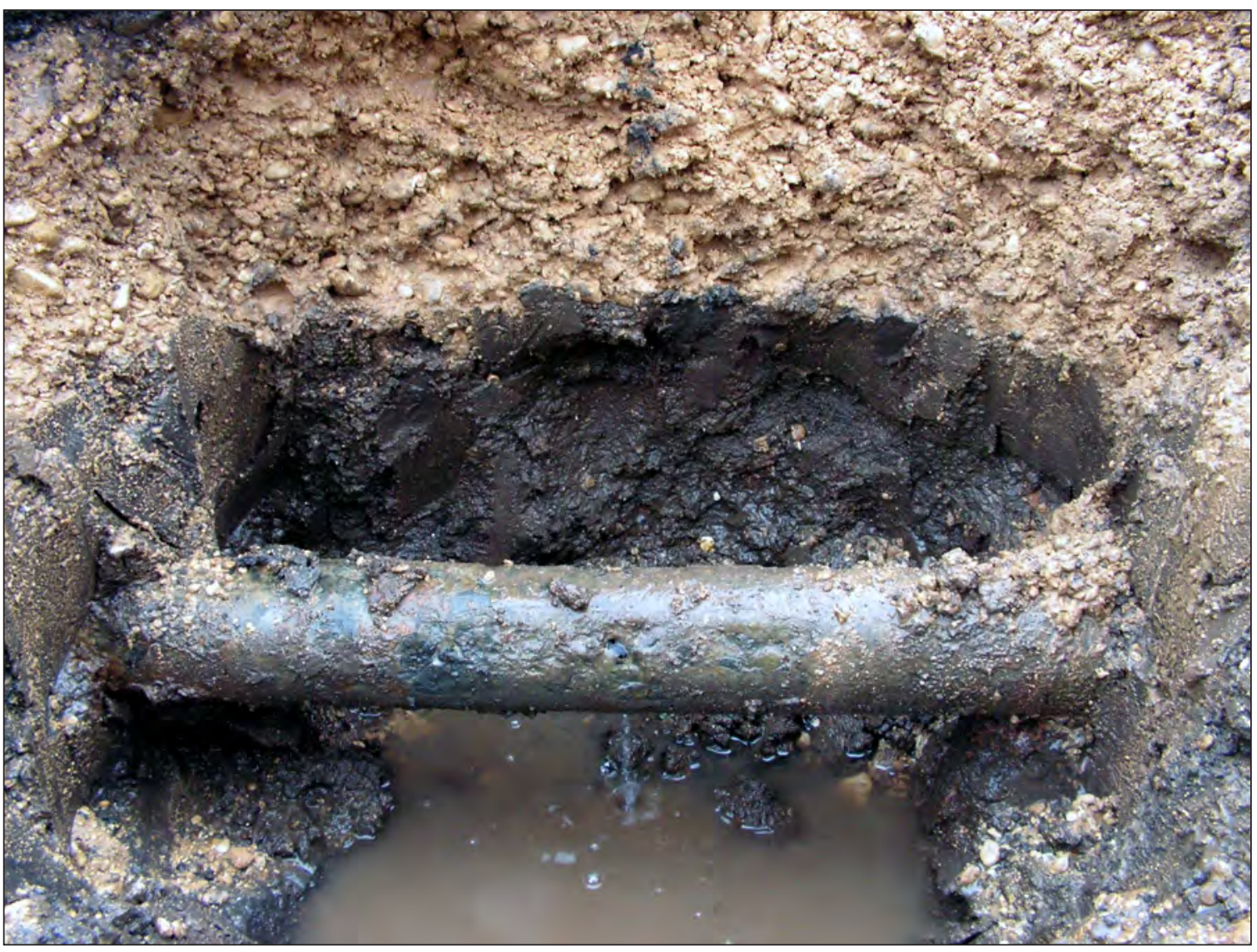

Figure 4-4. Exposed waterline. 


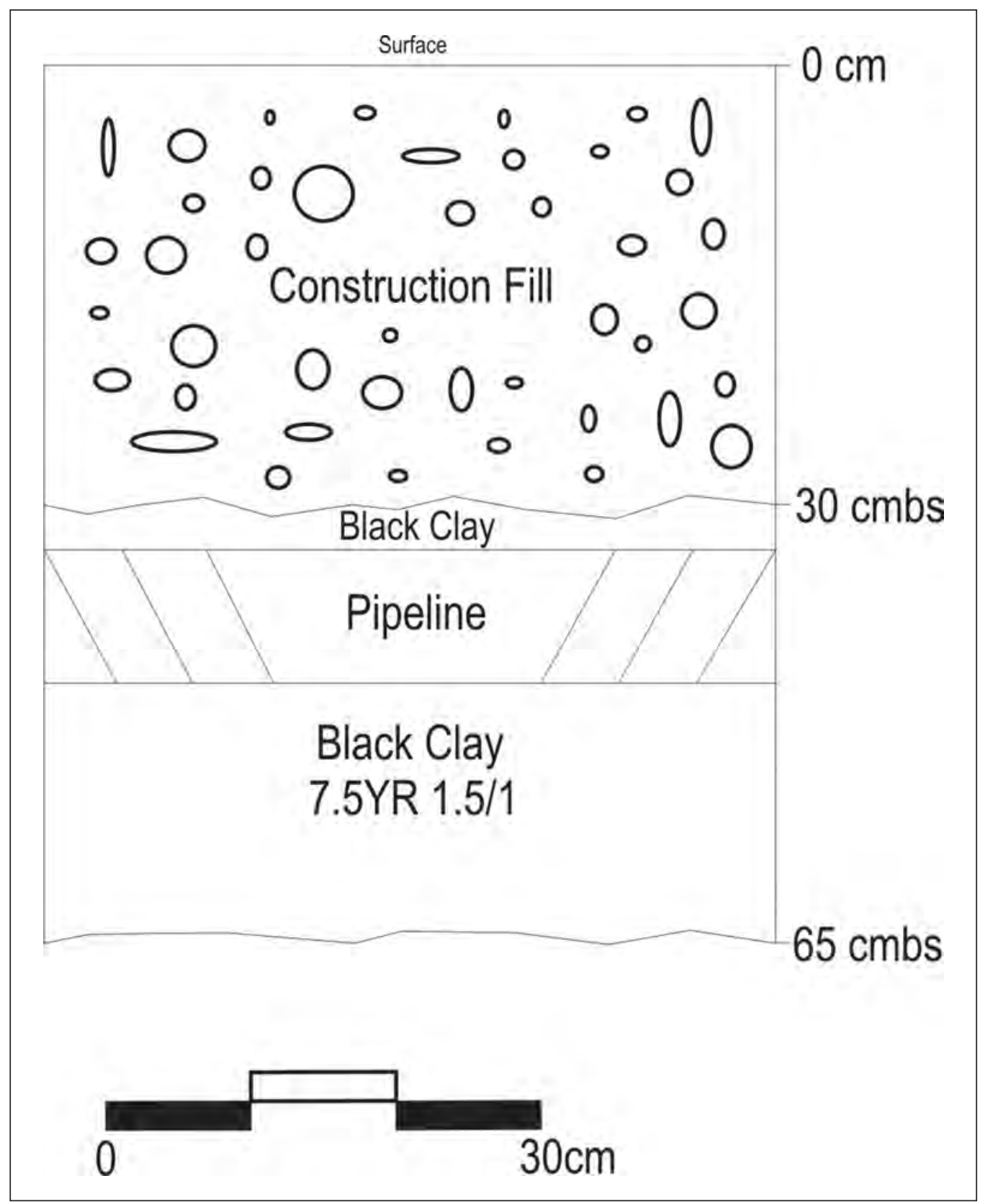

Figure 4-5. Excavation wall profile. 


\section{Chapter Five}

\section{Center for Research Commercialization 41HY477}

By Antonio Padilla and Julian A. Sitters

The University plans to develop a center to provide for the research, development, and commercialization of multifunctional materials to drive the development and innovation for the next generation of devices used in the fields of energy, security, and health. The Center for Research Commercialization will be constructed on 38 acres of University-owned land located at the southern corner of the intersection of Hunter Road and McCarty Lane (Figure 5-1). Eight buildings and associated interconnecting roadways and parking lots are proposed. Archival research into past owners and use of the property was conducted in advance of archaeological investigations. Archaeological investigations of this proposed location were undertaken in two phases. The first phase consisted of monitoring geotechnical boring and limited screening of the extracted sediment. The second phase consisted of an intensive archaeological survey.

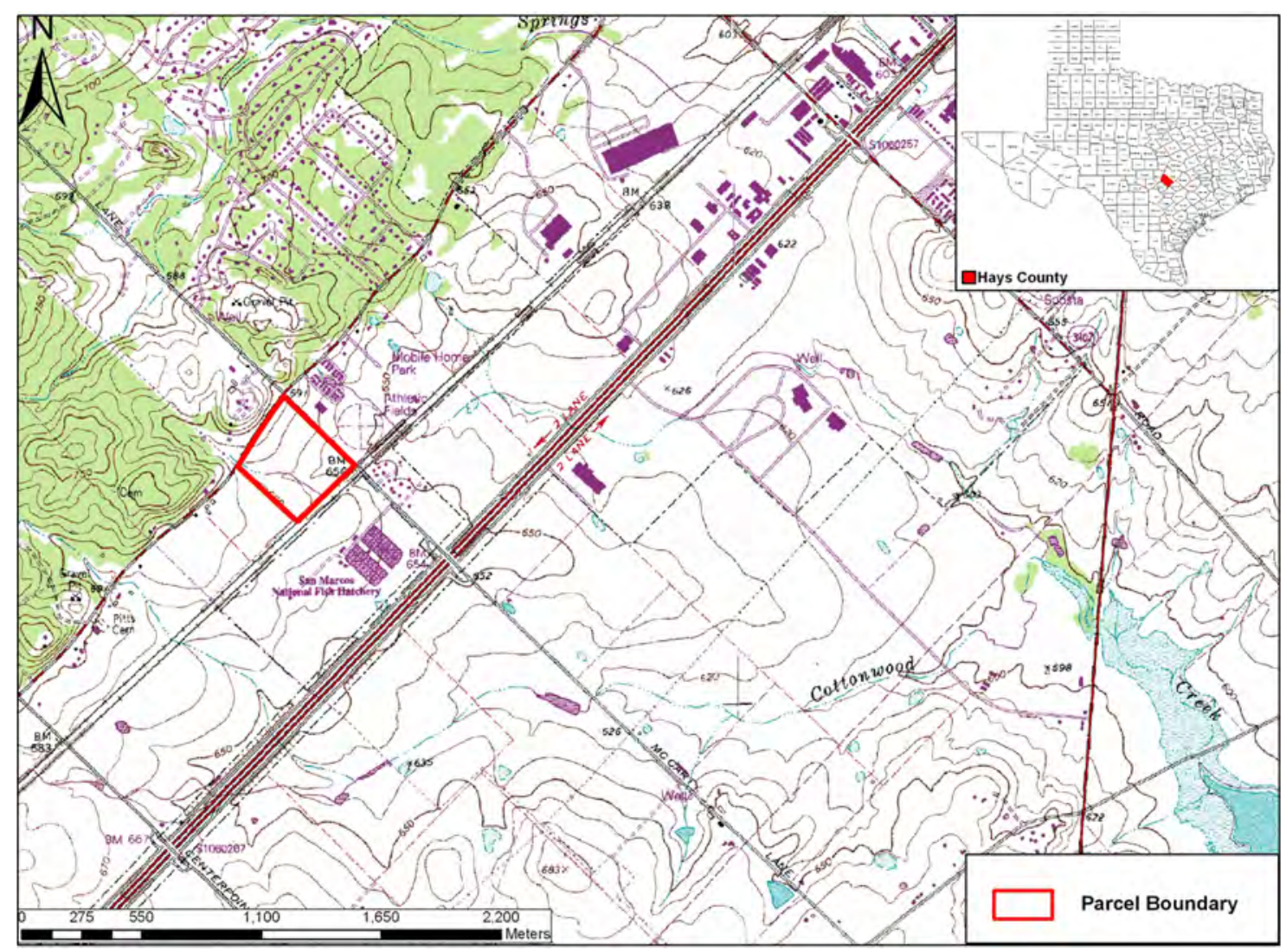

Figure 5-1. Center for Research and Commercialization project location. 


\section{Archival Research}

A deeds and records search was conducted of the property due to the presence of an abandoned cistern and water tank feature. The property is located in an area that was once known as Stringtown. Stringtown was one of the earliest Anglo-American settlements in Hays County. The community got its name from the approximately four-mile-long string of houses that were built facing the old San Marcos-to-New Braunfels post road between Purgatory Creek, southwest of San Marcos, and York Creek on the Hays-Comal county line (now Farm Road 2439). The town was occupied between 1850 and 1892 before eventually being abandoned. The purpose of the archival research was to identify historically notable persons possibly associated with the project area. Initial research involved examination of the primary sources in the deed, land title, and probate records.

An extensive review of deed records maintained at the Hays County Clerk's Office revealed that the property on which the development is located has a record of ownership that spans approximately 120 years. Records show that on February 16, 1917, Mrs. Anna Kyle, Emma Porter, Felix Swift accompanied by her husband L. W. Swift, and Mattie Swancoat sold two tracts of land totaling 393.29 acres to Bessie Gruene, wife of O. A. Gruene of Comal County, for the price of $\$ 29,271.85$. Although prior ownership of the land is unknown, it is stated in the deed that the first tract of land consisted of "104 acres of land, a part of and out of the Cyrus Wickerson Survey and 171.05 acres of land, a part of and out of the N. Hubbard Survey No. 35." The second tract consisted of " 87.79 acres of land, a part of and out of the John Williams League and 30 acres of land, a part of and out of the N. Hubbard Survey No. 35" (Hays County Deed Records [HCDR] Volume 71/Pages 218-220). The land described is composed of lands granted to the heirs of John Williams in 1846, Nathaniel Hubbard in 1849, and Cyrus Wickerson in 1849. According to records found online at the Texas General Land Office website, John Williams received 3123.36 acres, Nathaniel Hubbard received 640 acres, and Cyrus Wickerson received 948 acres. However, information regarding the conveying of land to Anna Kyle or any other person is not known, creating a gap in the distribution of land from the preceding years of ownership.

It is known that Bessie Gruene and her husband purchased the land in 1917 and maintained ownership of the property for 26 years, eventually selling all but 4.5 acres to $\mathrm{Mr}$. Charles Fehlis in 1943. The 4.5 acres not sold in 1943 to Mr. Fehlis was previously sold to the State of Texas for highway purposes in 1934 (HCDR 128/388-390). Mr. Charles Fehlis maintained ownership of the property for five years, after which he in turn sold it to the State of Texas for the use and benefit of the Southwest Texas State Teachers College of San Marcos in 1948.

In an affidavit of Use and Possession taken in 1948 (provided by Mr. David Bisett, Real Estate Specialist for the University), Mr. Eugene Posey testified that Bessie Gruene and her husband never lived on the land, and that they only rented or leased it to tenants who farmed and pastured livestock on it. According to his recollection prior to that, Mrs. Kyle only leased it as well. According to Mr. Posey, the property had been continuously cultivated since 1908 and continued to be cultivated when Mr. Fehlis acquired the property, who also leased the property to tenants.

Mr. Bisett stated that according to the neighboring property owner, Mr. Buddy Able, the only activities that have occurred on the land consisted of dairy farm operations conducted by the University and cultivations prior to that. No 
homes were ever located on the property, only barns and sheds. The cistern and watering tank encountered during the archaeological survey of the property are almost certainly related to any one of these activities.

\section{Project Setting}

The modern-day parcel under archaeological investigations consists of 38 acres characterized as an agricultural field primarily used for hay cultivation (Figure 5-2). A group of trees are located in the center of the parcel and along the northwestern and southwestern fence lines. The centrally located group of trees surrounds a stock pond that is fed by a drainage system, running from the northwest to the southwest corner of the property. During times of heavy rain, the field floods due to poor drainage conditions.

\section{Phase 1: Monitoring}

Monitoring of geotechnical boring was conducted by CAS archaeologist Julian A. Sitters on February 2, and 18, 2010. Geotechnical surveying was conducted by Holt Engineering and consisted of six bore holes, labeled Bore Holes A, B, C, D, $\mathrm{E}$, and $\mathrm{F}$ (Figures 5-3 and 5-4).

\section{Results}

No cultural materials were noted on the surface of the bore hole locations. Bore holes were excavated to a depth not greater than $10.6 \mathrm{~m}(35 \mathrm{ft})$ below ground surface. Sitters conducted limited sediment screening on the sediments extracted from Bore Holes A, B, and F. Bore Hole A was excavated to a depth of $4.5 \mathrm{~m}$ (15 ft), Bore Hole B to $2.7 \mathrm{~m}$ (9

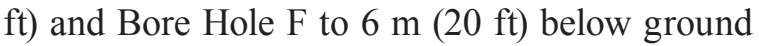
surface. No cultural materials were encountered during monitoring or limited screening of these three bore holes. The surface visibility at Bore Holes A, B, and F was poor, only 30 percent. The results are presented in Tables 5-1 through 5-3.

Following monitoring of the bore holes, a brief visual surface survey was conducted of the

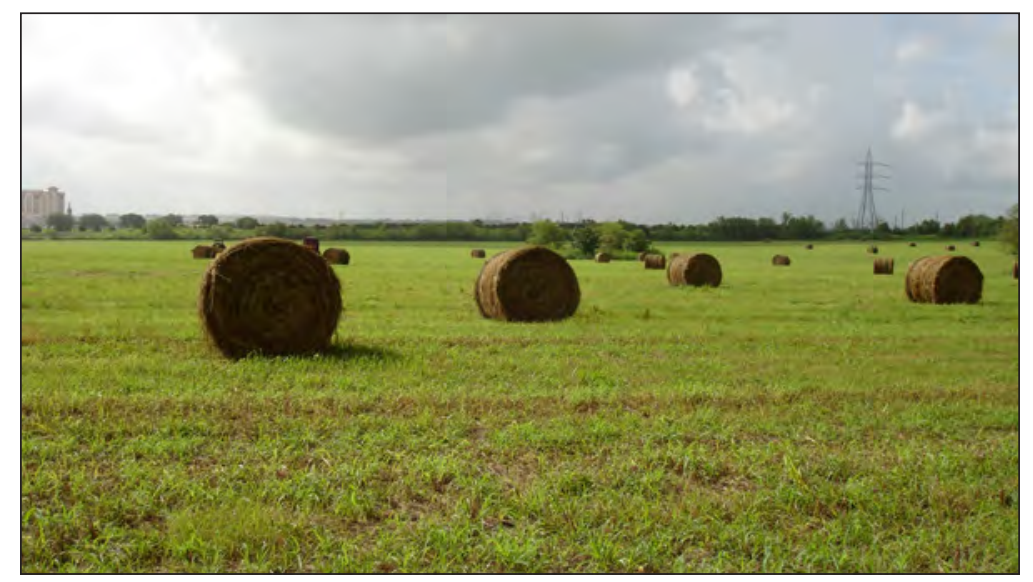

Figure 5-2. Overview of Center for Research Commercialization project area; facing southwest.

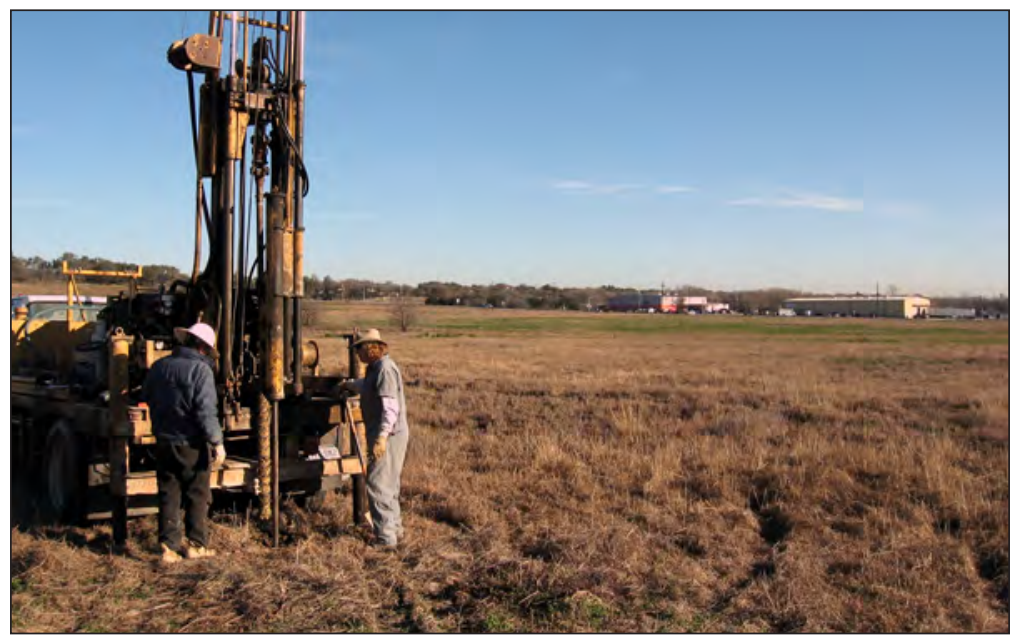

Figure 5-3. Geotechnical boring by Holt Engineering; facing north. 


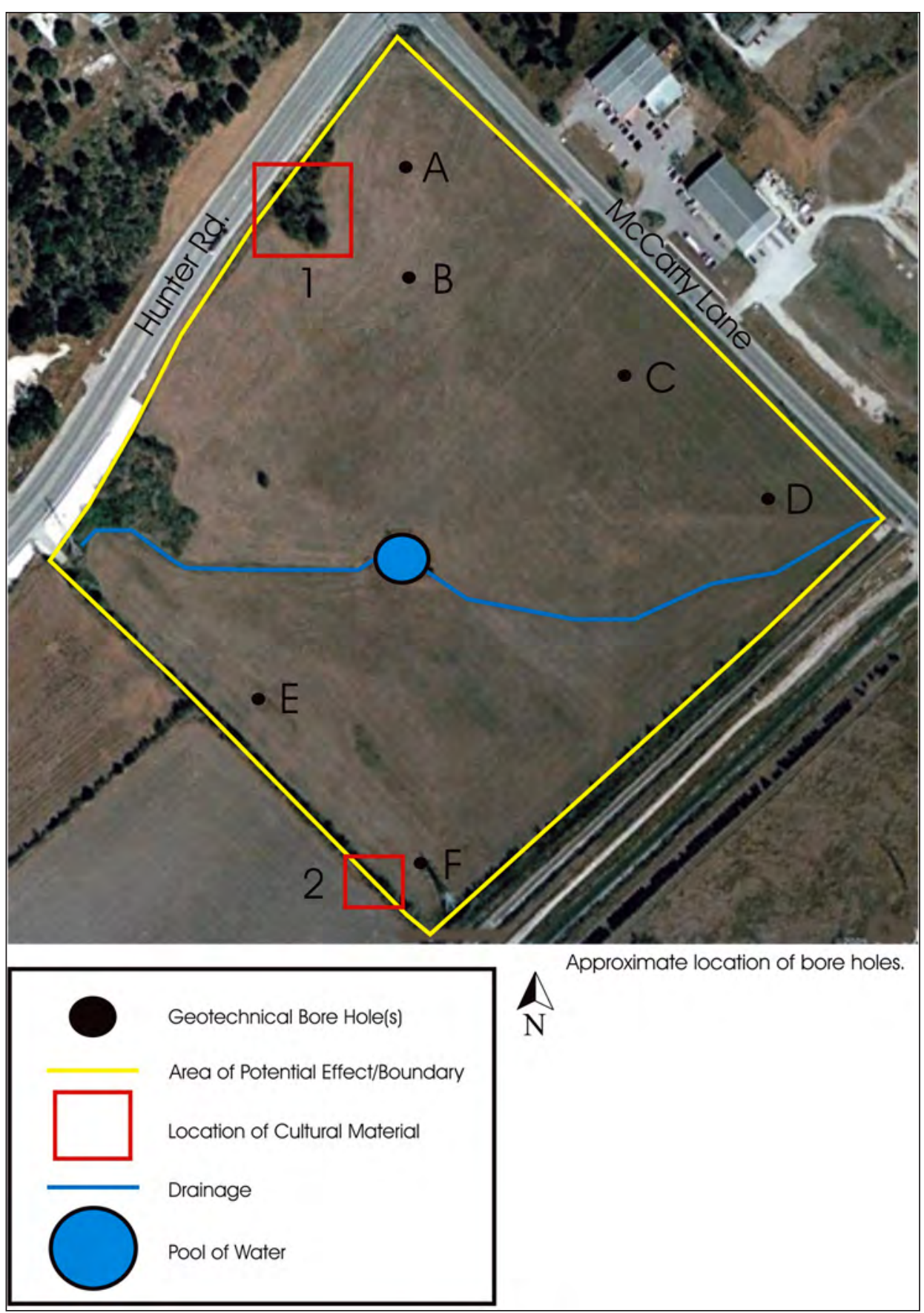

Figure 5-4. Locations of bore holes and cultural materials.

surrounding area. A concentration of cultural materials was identified and documented during this brief survey. This concentration was in a small grove of trees along the northwestern fence line and consisted of two concrete structures (water containment structures; Figure 5-5 and 5-6), one whiteware ceramic sherd, machine- cut wooden boards, thin corrugated sheet metal, and possible metal farming equipment parts. The sheet metal and wooden boards appear to have once formed a small shed before collapsing (Figure 5-7). This location was labeled Cultural Material Location 1 (see Figure 5-4). A second area of cultural materials was identified as 
Table 5-1. Results of Bore Hole A.

\begin{tabular}{cccc}
\hline Depth (ft) & Munsell & Soil Description & Notes \\
\hline $0-2$ & 10YR 3/3 & dark brown clay loam & \\
$2-4$ & 10YR 3/4 & dark yellowish brown clay loam & $\begin{array}{r}\text { Tan silty clay loam; limestone formations } \\
\text { present; mixed sediment (brown, yellow, white, } \\
\text { and red-like clay); at roughly 7-9 ft the clay } \\
\text { becomes less variable, 10YR 6/8; bed formation } \\
\text { (bedrock) present at } \sim 8.5-9.5 \mathrm{ft}\end{array}$ \\
$4-9$ & 10YR 6/8 & brownish yellow clay loam & $\begin{array}{r}\text { yellow clay loam } \\
15\end{array}$ \\
\hline
\end{tabular}

Table 5-2. Results of Bore Hole B.

\begin{tabular}{cccc}
\hline Depth (ft) & Munsell & Soil Description & Notes \\
\hline $0-2$ & 10YR 3/2 & $\begin{array}{c}\text { very dark grayish brown } \\
\text { dark gray-light yellowish } \\
\text { brown } \\
5-7\end{array}$ & 10YR 4/1-10YR 6/4 \\
9 & 10YR 6/4-10YR 6/6 & $\begin{array}{c}\text { light yellowish brown- } \\
\text { brownish yellow }\end{array}$ & $\begin{array}{c}\text { Mixed sediment (orange/brown, yellow, } \\
\text { and white clay loam); bed formation }\end{array}$ \\
\hline
\end{tabular}

Table 5-3. Results of Bore Hole F.

\begin{tabular}{|c|c|c|c|}
\hline Depth (ft) & Munsell & Soil Description & Notes \\
\hline $0-2$ & $1 Y R 3 / 1-3 / 2$ & very dark gray-dark brown clay loam & \\
\hline $2-4$ & 10 YR $6 / 4$ & light yellowish brown clay loam & \\
\hline $4-9$ & $2.5 \mathrm{YR} 8 / 8$ & yellow clay loam & $\begin{array}{c}\text { At } 9 \mathrm{ft}, 2.5 \text { YR } 6 / 6-6 / 8 \text { olive yellow } \\
\text { Taylor clay loam; very dry; limestone } \\
\text { formations present; bed formations at } \\
5 \mathrm{ft} \text {; mixed sediment (brown, yellow, } \\
\text { white, and red-like clay) }\end{array}$ \\
\hline 20 & 2.5 YR $6 / 6-6 / 8$ & olive yellow Taylor clay loam & \\
\hline
\end{tabular}

Cultural Material Location 2. This area consisted of fragmented concrete slabs, thin corrugated sheet metal, and bound barbed wire located along the southwestern fence line (see Figure 5-4). Following consultation with the THC/State Historic Preservation Officer (SHPO), it was concluded that the area should be subject to an intensive archaeological survey.

\section{Phase 2: Survey}

\section{Methodology}

CAS Project Archaeologist Antonio Padilla and field technician Sarah Scogin conducted an intensive archaeological survey on July 7 and 8,2010 , consisting of a visual inspection of the project area and the excavation of shovel tests. 


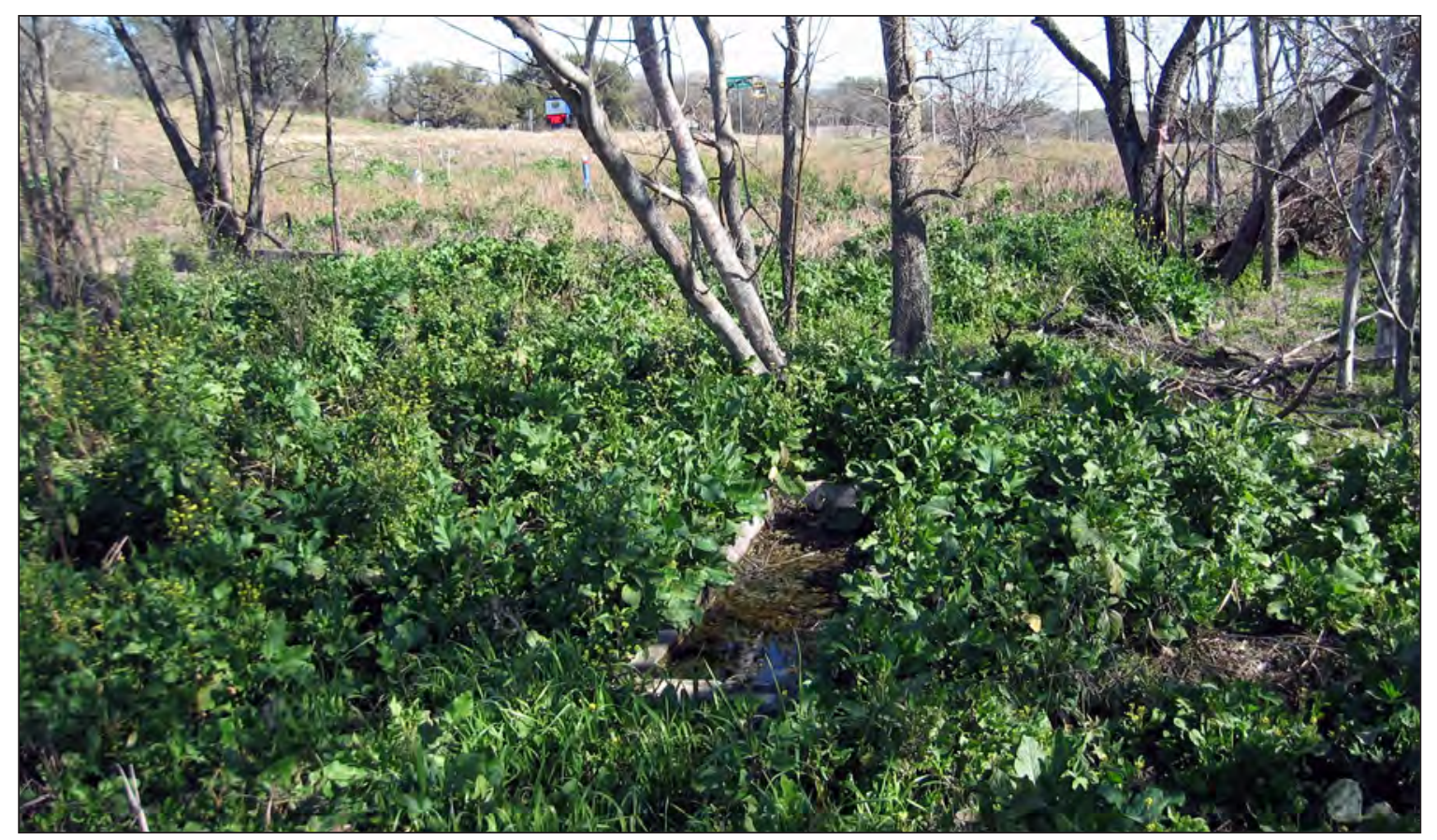

Figure 5-5. Concrete trough.

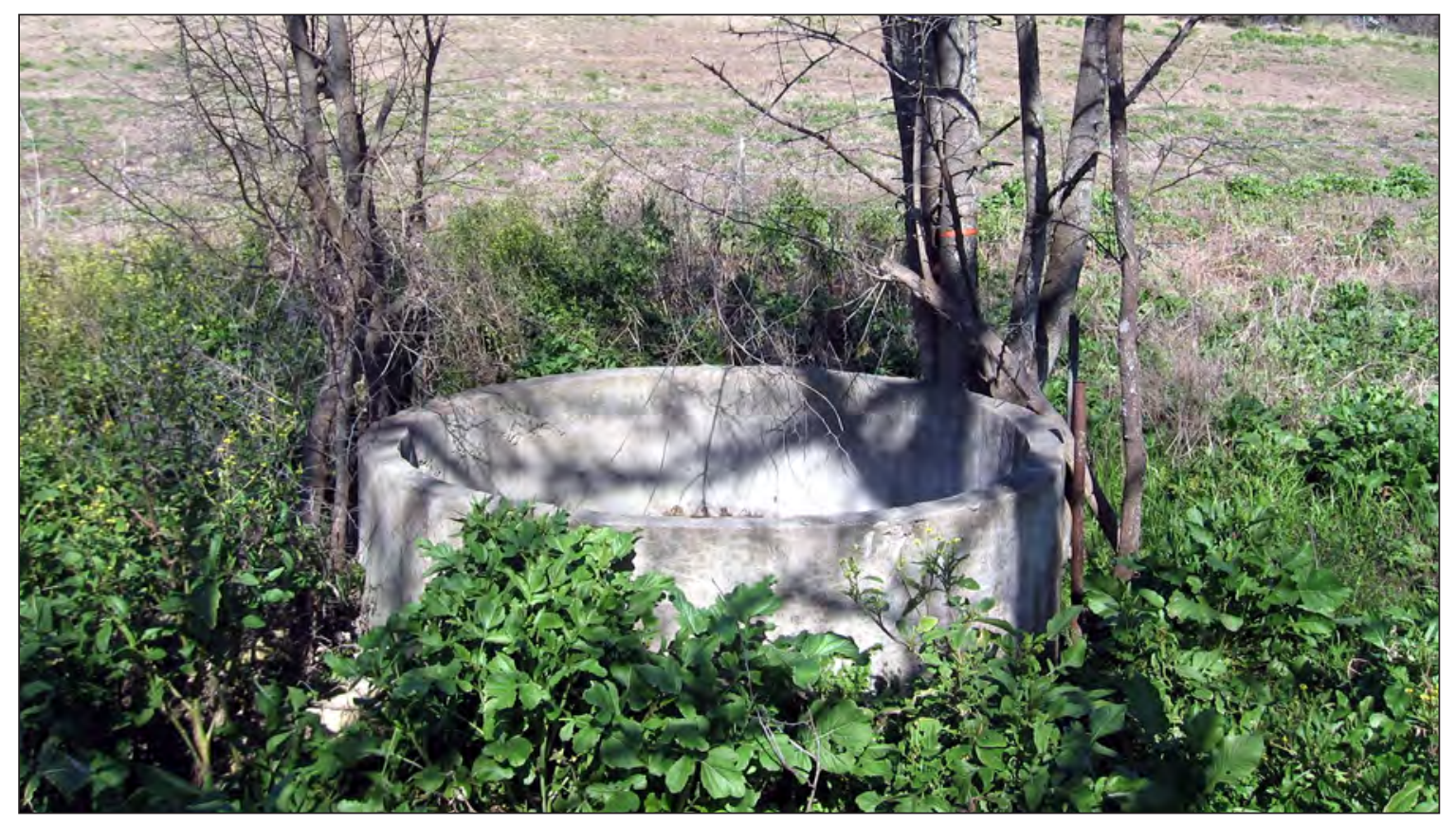

Figure 5-6. Concrete cistern. 
Survey methodology exceeded the minimum survey standards established by the THC and the Council of Texas Archeologists. Pedestrian survey involved a systematic examination of the ground surface along 13 transect lines set at 30-m intervals across the property. Shovel tests were excavated at a rate of one test per two acres, for a total of 19 shovel tests (Figure 5-8). Shovel tests were $30 \mathrm{~cm}$ in diameter and were manually excavated in arbitrary $20-\mathrm{cm}$ levels to a depth of $80 \mathrm{~cm}$ below surface (cmbs), or upon reaching heavily disturbed deposits or hard, impenetrable clays. All excavated sediments were screened through 1/4-inch mesh screen. Information consisting of depth of excavation, soil type, soil color and cultural material present were recorded on standardized forms. The UTM location of each shovel test was also recorded with a handheld Trimble GeoXT GPS unit.

\section{Results}

During the systematic pedestrian survey, CAS archaeologist relocated Cultural Material Locations 1 and 2. Location 1 consisted of an above-ground concrete cistern measuring 2.08 $\mathrm{m}$ in diameter (see Figure 5-6) and a concrete trough measuring $2.05 \times 0.70 \mathrm{~m}$ (see Figure 5-5). These features were observed next to a collapsed structure consisting of a corrugated tin roof measuring approximately $2.5 \times 3.5 \mathrm{~m}$ (see Figure 5-7). The corrugated tin was attached to machine-cut wood with round nails, suggesting a modern age. Farm equipment parts and a single whiteware ceramic sherd were also noted on the ground surface. Location 2 contained fragmented concrete slabs, thin corrugated sheet metal, and bound barbed wire. These materials were considered to be modern in age and associated with discarded trash along the property boundary.

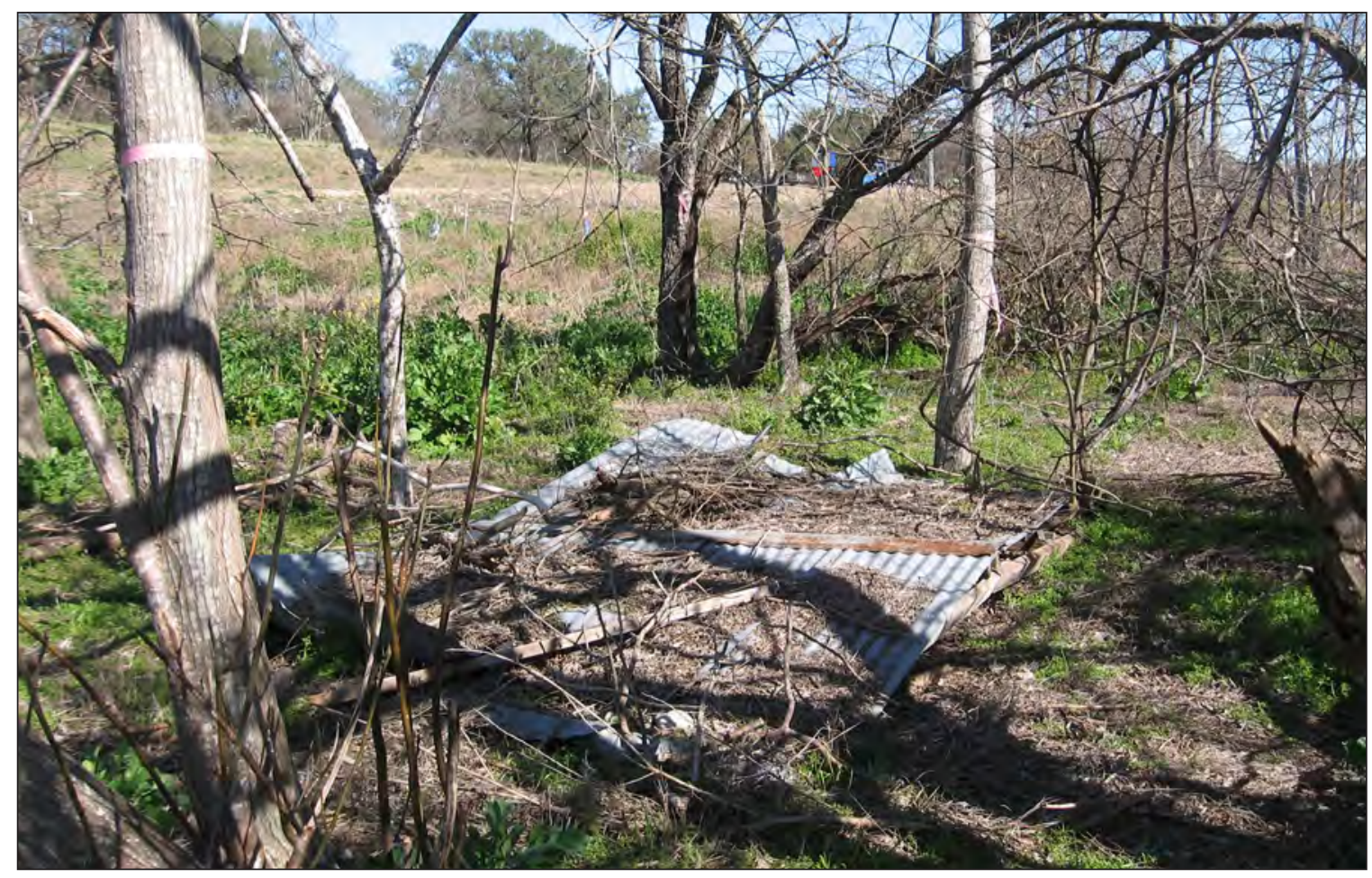

Figure 5-7. Collapsed metal-roofed shed. 


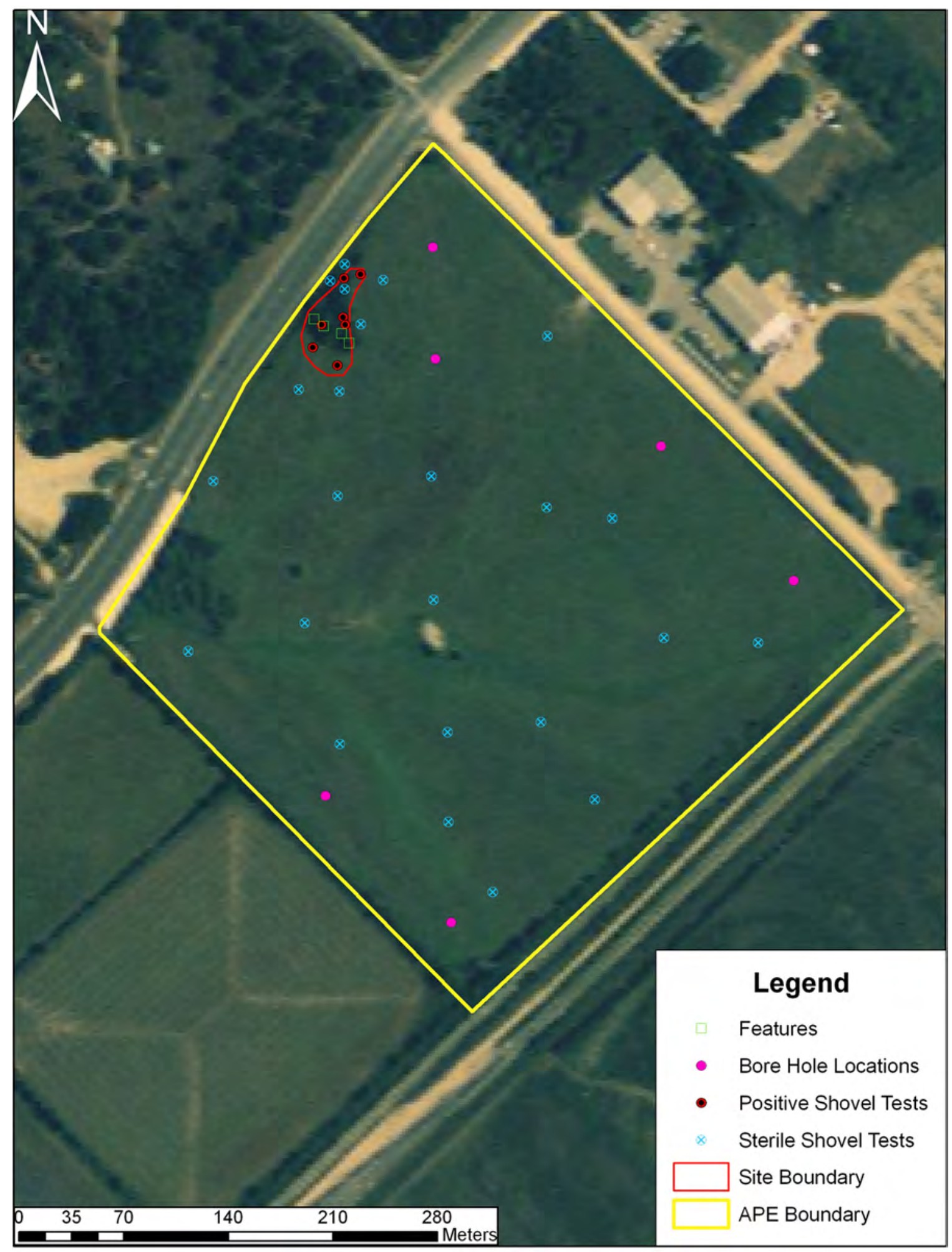

Figure 5-8. Shovel test locations, bore hole locations, and site boundary. 
Nineteen shovel tests were excavated in conjunction with the systematic pedestrian visual survey (see Figure 5-8; Appendix A). Only one shovel test excavated yielded cultural material (TR1, ST1). This shovel test was excavated approximately $50 \mathrm{~m}$ northeast of Location 1 . Encountered cultural material consisted of a single cut nail and a piece of window glass at a depth of $0-20 \mathrm{cmbs}$. An additional 12 shovel tests (TR1, ST1.1 through ST1.12) were excavated to determine the vertical and horizontal distribution of possible cultural deposits. Five of the additional 12 shovel tests contained cultural material between 0 and $40 \mathrm{cmbs}$, with the majority located between 0 and $20 \mathrm{cmbs}$ (Appendix A). Encountered material included window glass, clear and blue glass, earthenware and whiteware ceramic sherds, and faunal bone.

These cultural deposits were recorded as site 41HY477. The site does not appear to retain good depositional context throughout. For example, road base material was encountered at $20 \mathrm{cmbs}$ in two shovel tests excavated near the fence line bordering Hunter Road. A TexSite Data Form was completed and submitted to TARL.

\section{Recommendations}

Based on features present on the surface, this site is believed to represent activities related to rural agricultural (farming and cattle) activities and production. An ephemeral, shallowly buried scatter of historic material intermixed with modern debris was identified during archaeological investigations in the northwestern portion of the 38 -acre parcel. This area was designated as archaeological site 41HY477. The excavation of shovel tests indicated that the majority of this historic material is located in the upper $20 \mathrm{~cm}$ of the site, with some areas continuing to $40 \mathrm{~cm}$. Modern cultural material was also located in the upper $40 \mathrm{~cm}$ of the site, indicating mixed deposits. These areas suggest that the contextual integrity of the site is poor. The site is currently a maintained agricultural field that has been repeatedly plowed. All materials encountered within the plow zone (estimated to be ca. $20 \mathrm{cmbs}$ ) are heavily disturbed and in a mixed context. Due to the disturbed nature of the site and low integrity of deposits, this site is not considered to possess any research potential. CAS recommended that the site not be eligible for nomination to the NRHP or designation as an SAL. CAS recommended that the University be granted regulatory clearance to proceed with this undertaking without further concern for negative impacts on cultural resources.

This information was presented to $\mathrm{THC} /$ SHPO in an interim letter report on August 18, 2010. The THC/SHPO concurred with the abovedescribed findings and recommendations on September 13, 2010 (Appendix B). 


\section{Chapter Six}

\section{Blanco Hall}

By Julian A. Sitters

On March 23, 2010, Texas State University Facilities Services excavated a trench $4 \mathrm{~m}$ wide and $2.1 \mathrm{~m}$ deep in order to repair a fractured condensation line located in front of Blanco Hall (Figures 6-1 and 6-2). At the request of the University, CAS archaeologist Julian A. Sitters conducted monitoring of the excavation to assess potential impacts to culturally sensitive material(s).

\section{Results}

No significant historic or prehistoric cultural materials were present within the excavated area. Modern debris was present throughout the excavated trench and consisted of bricks, glass, a lighter, plastic, electrical wire, abandoned pipes, and metal fragments. After monitoring the excavation, it was determined that the excavated area consisted solely of construction fill. The construction fill included fine-grained sand, limestone, and an organic-rich top soil.

\section{Trench Soil Profile}

- Organic top soil: $10 \mathrm{YR} 3 / 3$

- Construction fill: 10YR 6/8 sandy sediment consisting of sand, mottled clay, and limestone cobbles.

\section{Construction Fill}

Multiple individuals stated that during the construction of Blanco Hall, a considerable

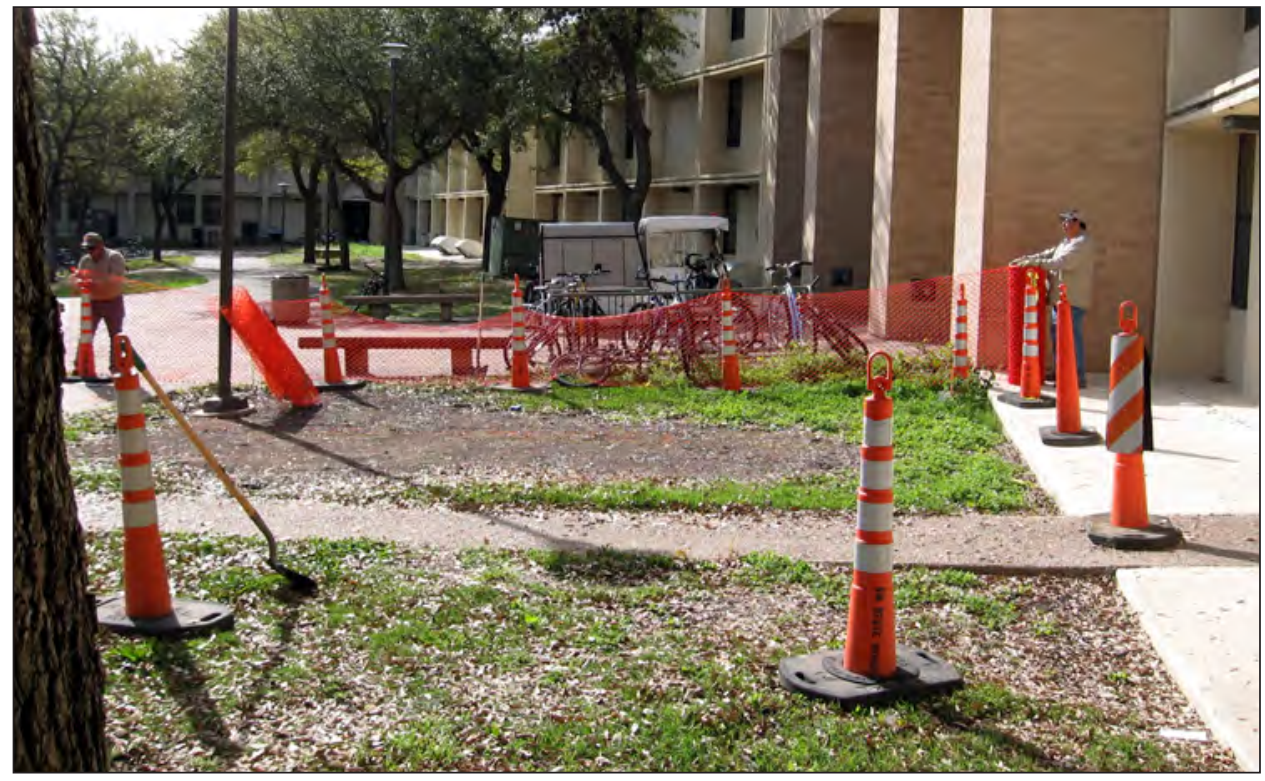

Figure 6-1. Trench location in front of Blanco Hall. 


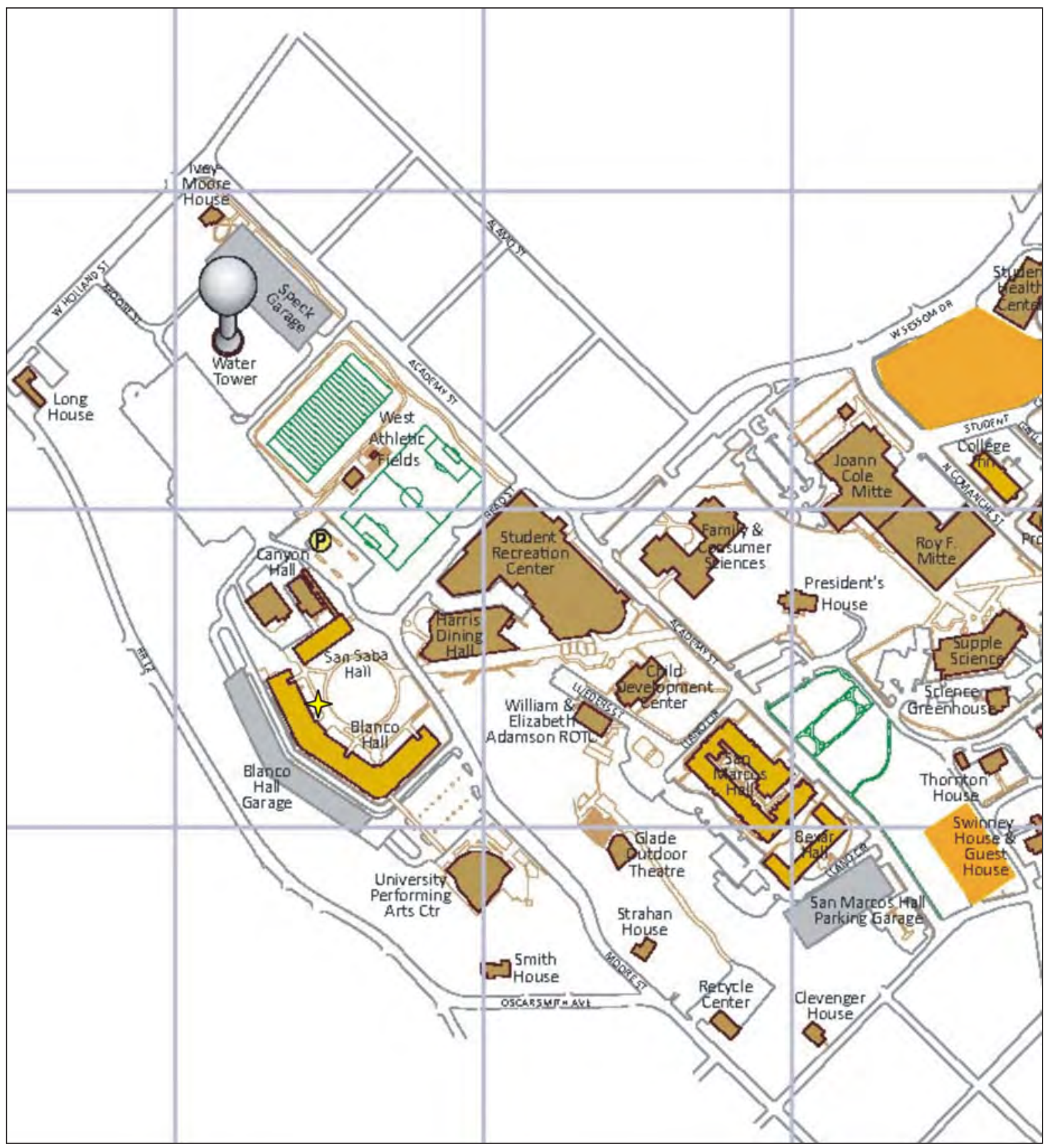

Figure 6-2. Blanco Hall project location (yellow star).

amount of fill was brought in to provide support for the new building. In some areas it is believed that as much as $20 \mathrm{ft}$ of fill was deposited. The fill is not just restricted to the location of Blanco Hall, but also extends out past Blanco Hall into the surrounding area. This information was provided by University Facility and Irrigation employees. This was based on past work experiences within the area and recollections of the construction in the 1970s.

\section{Recommendations}

As no cultural materials were observed, no additional archaeological investigations were warranted or recommended. 


\section{Chapter Seven}

\section{Freeman Ranch}

By Julian A. Sitters

On March 24, 2010, CAS archaeologist Julian A. Sitters monitored four trenches excavated by Texas State University Facilities Services at the Freeman Ranch property located off of Ranch Road 12 in Hays County (Figure 7-1). Trenches measured $3 \mathrm{~m}$ long by $1.4 \mathrm{~m}$ wide and were excavated to bedrock, ca. $47 \mathrm{cmbs}$. Monitoring was performed to assess possible impacts to culturally sensitive material(s). The project area is characterized as an upland region, containing short grasses, cacti, scattered short trees, limestone cobbles/slabs, and chert nodules on the surface (Figure 7-2). Cattle roam the property, trampling the ground and possibly destroying or affecting cultural material on the surface. Ground surface visibility was approximately 60 percent and the soil was rich, organic topsoil.

Cultural materials have been noted on the Freeman Ranch property during a previous archaeological survey conducted by CAS (Yelacic and Lohse 2008). These cultural materials were characterized as ephemeral surface upland lithic scatters that were occurred sporadically

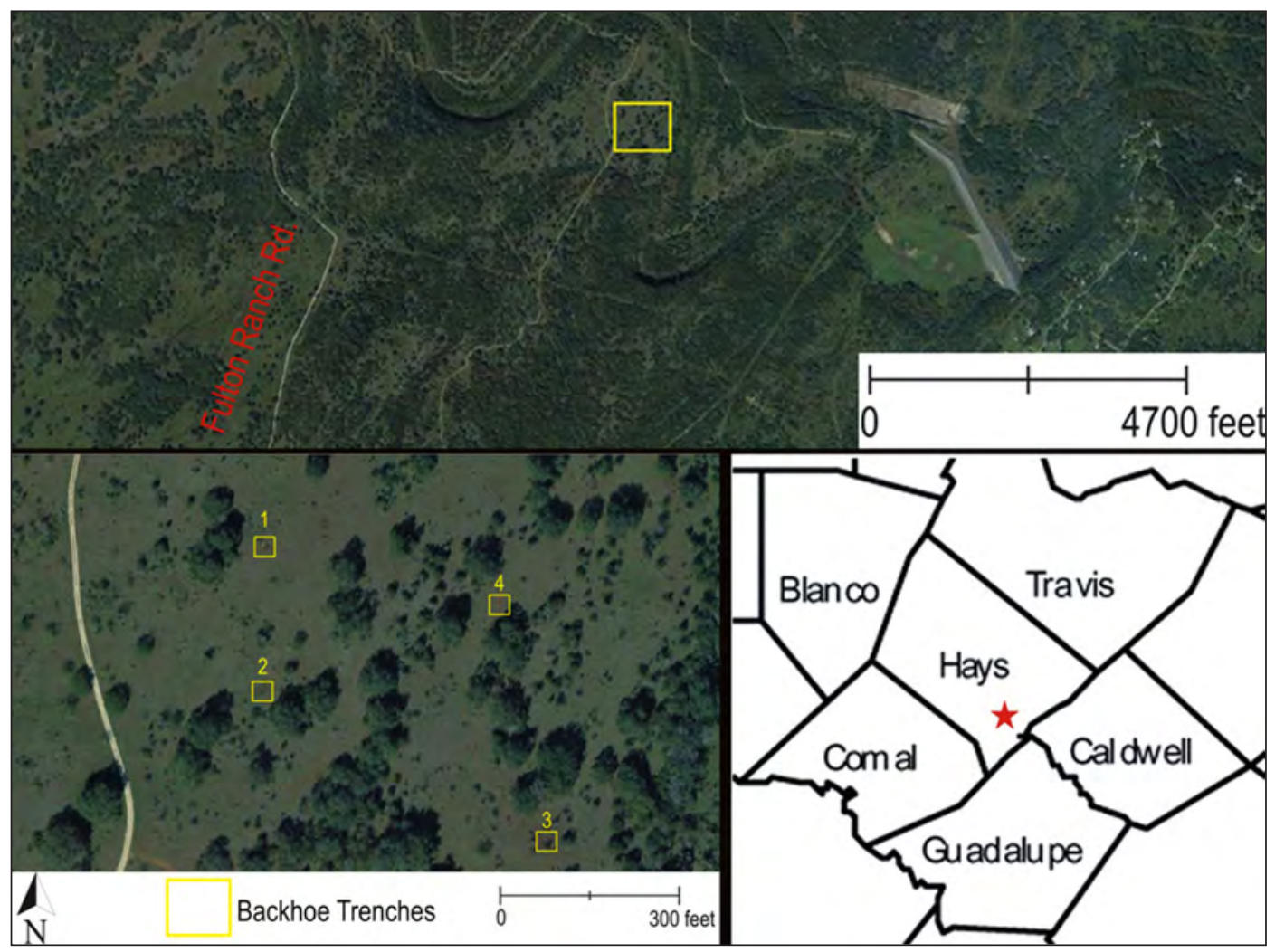

Figure 7-1. Freeman Ranch project and backhoe trench locations. 
across the property. One site, 41HY447, was recorded during the previous survey and contained angular chert, flake cores, and tested cobbles. The trenches monitored in the current effort posed no immediate threat to this site or to other known cultural resources.

\section{Results}

No cultural materials were recovered or identified within any of the four trenches; however, cultural materials were present on the surface near Trenches 2 and 3. Noted cultural material included a tested cobble and possible flake cores (Figure 7-3). The presence of these materials on the surface suggests a lack of buried cultural material. All excavated trenches contain the same stratigraphic profile; a general description of this sequence is presented below.

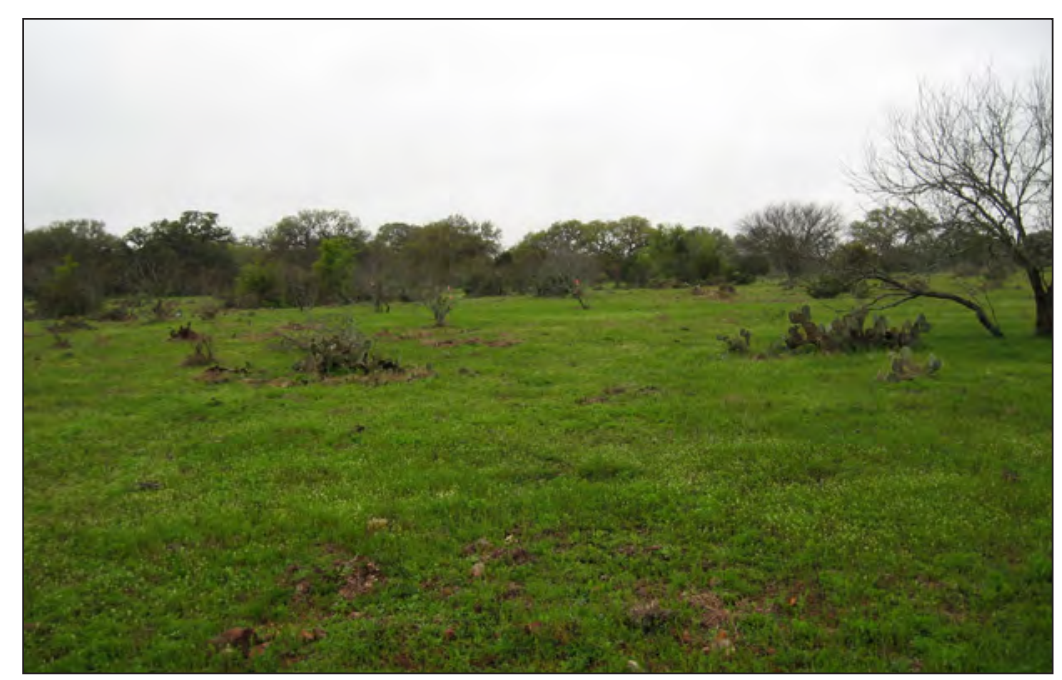

Figure 7-2. Project setting, facing west.

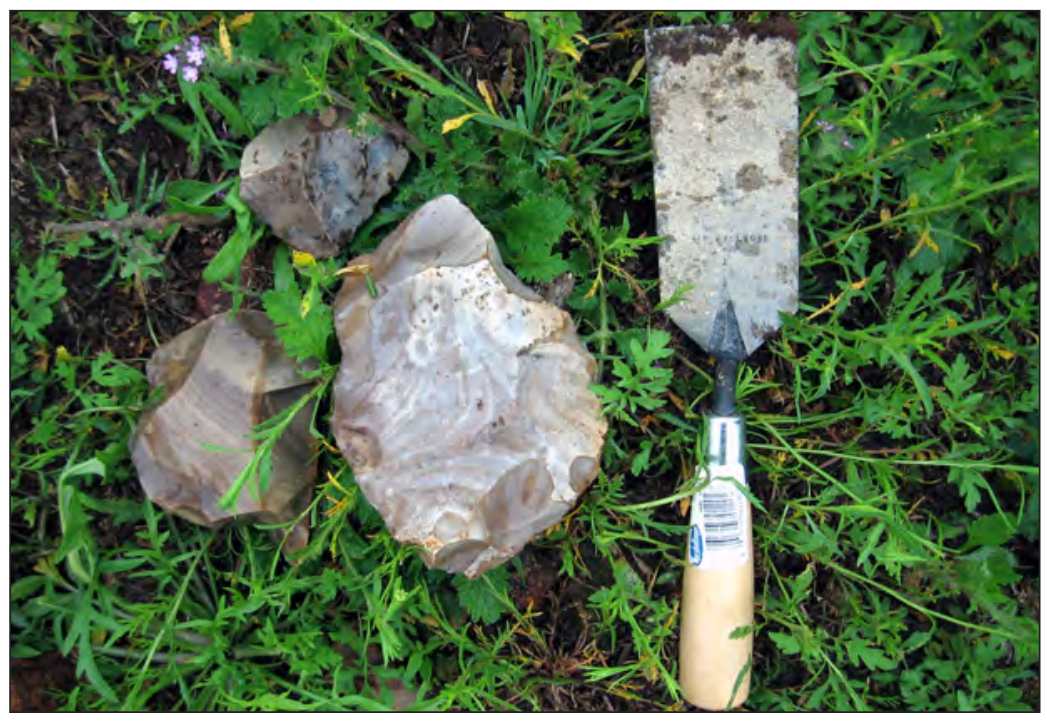

Figure 7-3. Possible flake cores.

\section{Trenches 1-4: Soil}

\section{Profile Descriptions}

- The upper sedimentary deposit consists of a sandy clay loam, 10YR 3/3.

- The bottommost sedimentary deposit consists of a clay loam, 5YR 3/4.

- Limestone cobbles were present throughout each trench.

- Each trench was closed once reaching bedrock around $47 \mathrm{cmbs}$.

\section{Recommendations}

While no prehistoric cultural remains were encountered in any of the excavated trenches, the presence of chipped stone artifacts near Trenches 2 and 3 indicates that prehistoric cultural materials are present at Freeman Ranch. CAS recommends that future impacts at Freeman Ranch either be monitored, similar to the current effort, or preceded by archaeological survey such as the one that recorded site $41 \mathrm{HY} 447$ (Yelacic and Lohse 2008). 


\section{Chapter Eight}

\section{Fish Ponds}

By Julian A. Sitters

On April 2, 2010, Texas State University Facility Services were forced to excavate two backhoe trenches in the area of the old fish hatchery ponds to locate a waterline break. CAS archaeologist Julian A. Sitters monitored the excavation of these trenches. The project area is located within SAL 41HY161. Archaeological monitoring of the excavation was conducted to assess probable impacts to cultural deposits.

The old fish hatchery ponds were constructed by building up and using the surrounding sediments, creating the topography present today. Shortgrassesand treesare presentwithin theareain addition to multiple fish ponds. The San Marcos River is located slightly downslope from the project area. Two backhoe trenches were excavated to the east of the JC Kellam administrative building, between one of the old fish ponds and a cement water retention pond to the north (Figures 8-1 and 8-2). The trenches were excavated until the waterlines were exposed, which was at roughly $120-170 \mathrm{cmbs}$.

\section{Results}

Cultural materials were recovered from the trenches. Artifacts appear to be in disturbed

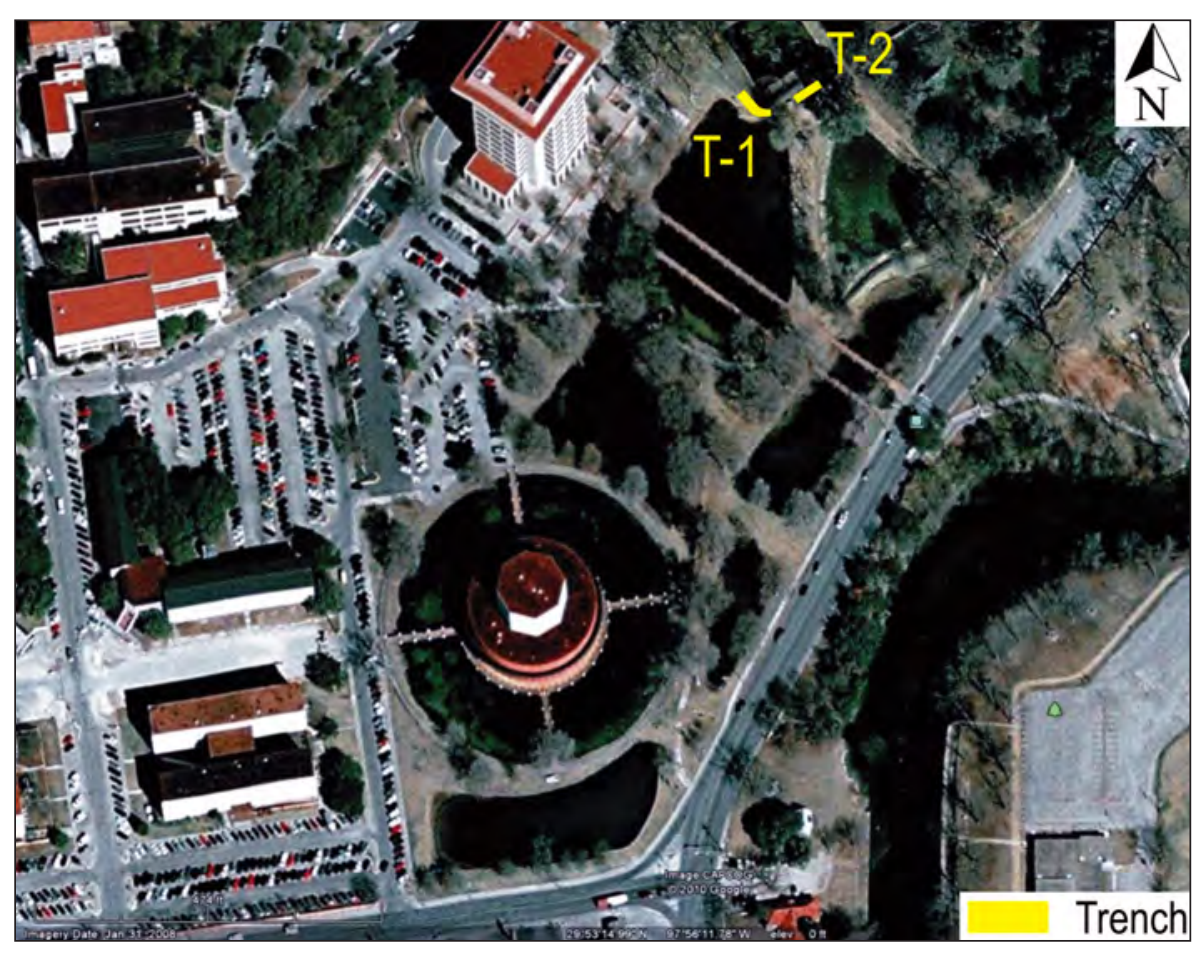

Figure 8-1. Backhoe trench locations. 
contexts based on observed mottled clay loam(s) above construction fill (fine sand and pebbles). Pipelines were located directly below the mottled clay and atop the construction fill layer (Figure 8-3). Ten chert flakes (some burned), burned limestone (not collected), one biface, one biface fragment (lateral edge), and one piece of burned fauna were recovered from the trenches' backfill. This material is concentrated at or near the surface to a depth of $20 \mathrm{cmbs}$. The presence of cultural materials at this depth suggests that sediment was removed during the installation of water and electrical lines, construction fill was then added to support the installed lines, and then the previously removed sediment was deposited over the lines. After completing the trench excavations, backfill was used to refill the excavated trenches, mixing the cultural materials yet again. According to many of the Facility Services employees, the project area has been disturbed multiple times through this type of impact. Modern debris consisting of bricks and plastic was also present in the backfill. As the soil profiles of each of the backhoe trenches were similar, they are reported together below.

\section{Backhoe Trenches 1 and 2: Soil Profiles}

- The upper deposit consists of a mottled clay loam, 10YR 3/3-2/2.

- The bottommost deposit consists of construction fill.

- Cultural materials were present in both trenches (backfill).

- Trench 1 measured $120 \mathrm{~cm}$ in depth. 


\section{Chapter Nine}

\section{President's House Irrigation System Trenching}

\section{By David Yelacic}

On April 13, 2010, CAS archaeologist David Yelacic conducted archaeological monitoring of trench excavations by University Grounds and Irrigation crewmembers to install a new sprinkler system for the President's House. Excavations were located between the President's House to the southeast and the Family and Consumer Sciences Building to the northwest (Figure 9-1). The project entailed manual excavation of two pits, which exposed the main waterline connection (tap trench) and the terminus connection (terminal trench) (Figure 9-2). A linear trench was mechanically excavated by a Ditch Witch. The distance between the tap and terminal trenches was approximately $25 \mathrm{~m}$. Due to the presence of several old and relatively large oak trees, however, the irrigation line trench was extended for $60 \mathrm{~m}$, effectively circumventing the grove of trees and their roots. Archaeological monitoring of excavation work in this area was deemed necessary, as archaeological site $41 \mathrm{HY} 318$ is located on the northern perimeter of the President's House location (Jones 2003).

\section{Results}

Pits excavated by shovel at both connection points contained previously disturbed sediment.

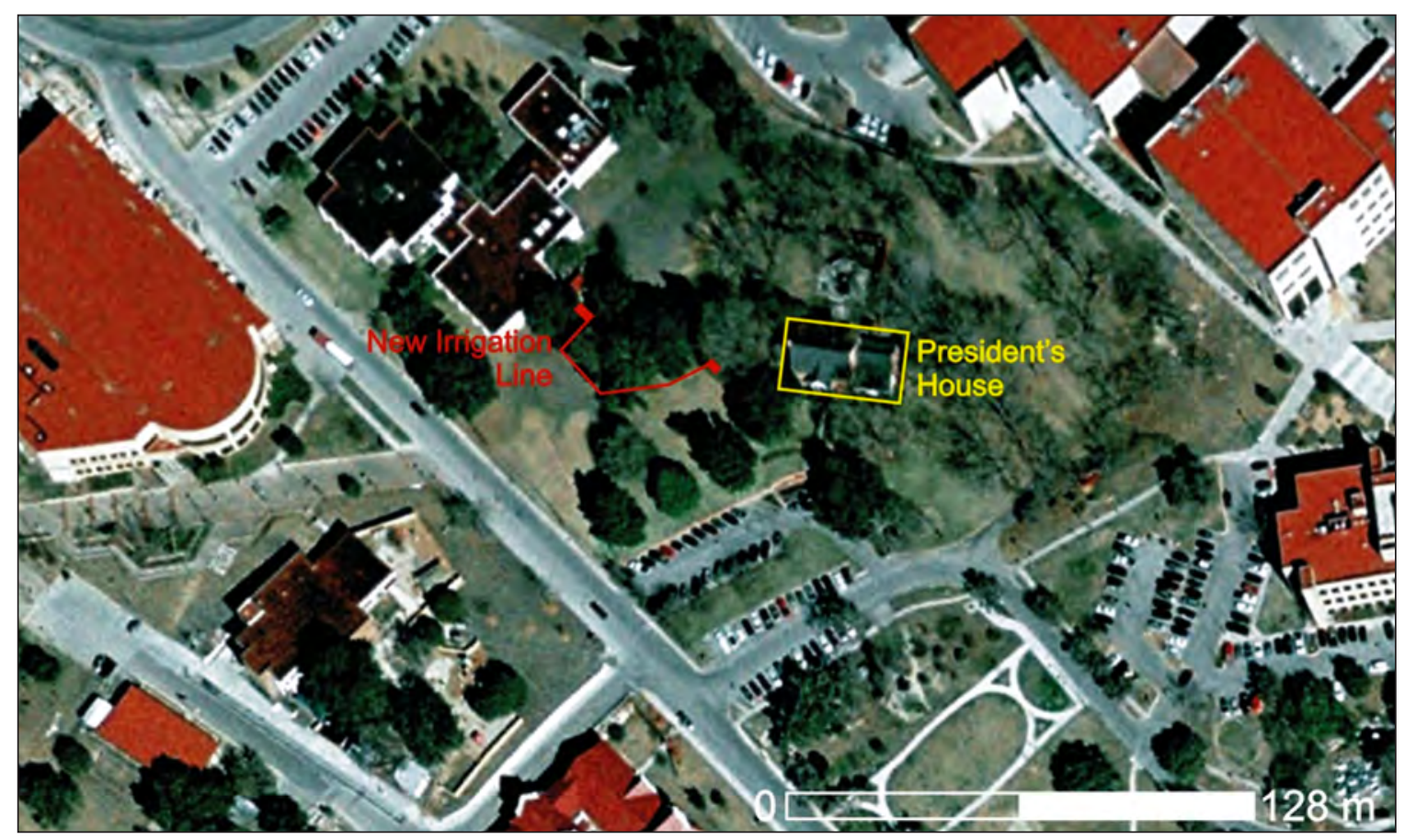

Figure 9-1. President's House irrigation trench project location. 


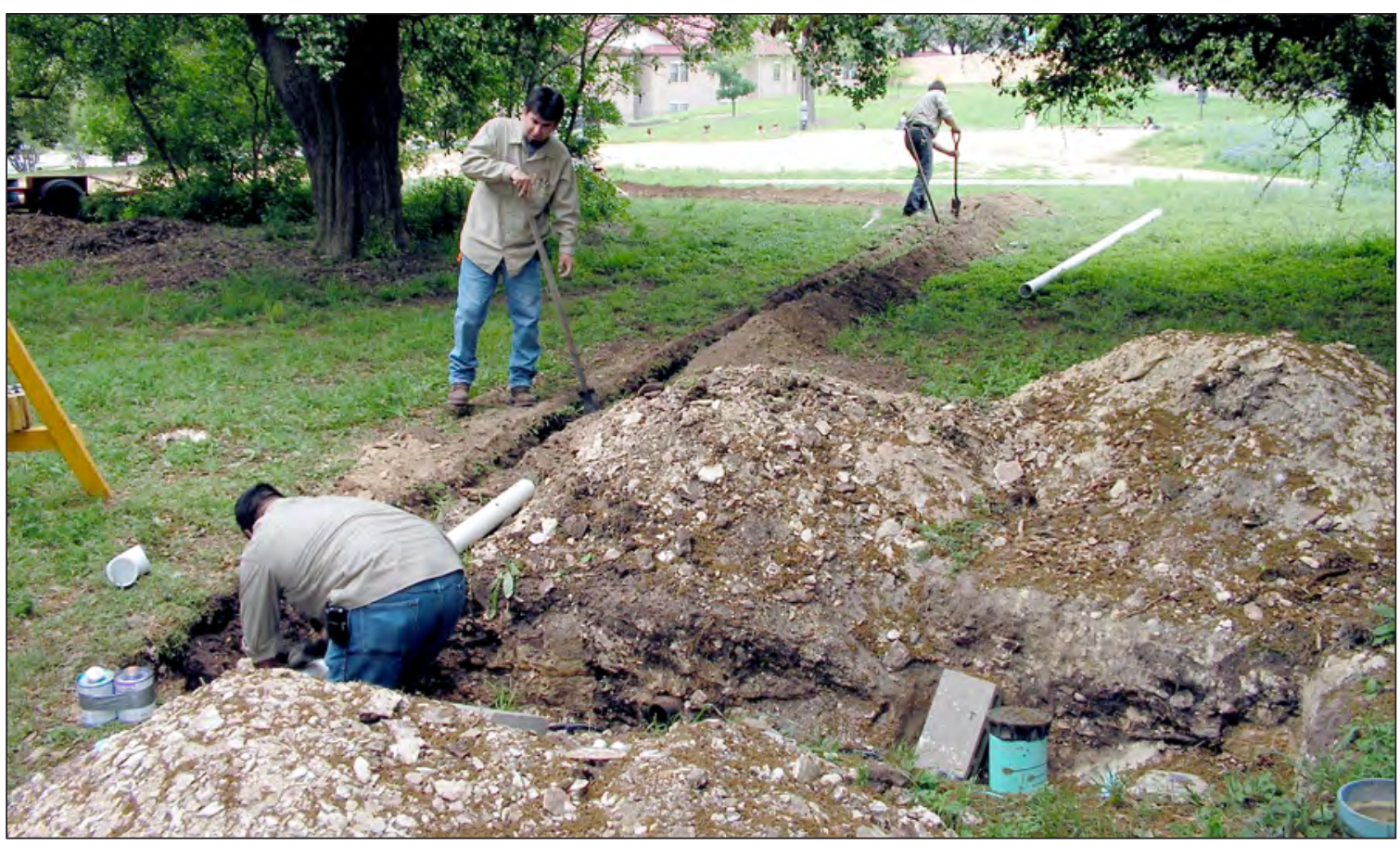

Figure 9-2. Texas State University's Grounds and Irrigation crewmembers excavating trench adjacent to the President's House; facing southwest.

The tap trench measured approximately $2 \times 1 \mathrm{~m}$ and was less than $50 \mathrm{~cm}$ deep, and the terminal trench measured approximately $1 \times 0.60 \mathrm{~m}$ and was about $50 \mathrm{~cm}$ deep. In both trenches, profile exposures revealed $15-20 \mathrm{~cm}$ of topsoil directly overlying marly, chalky limestone bedrock (Figure 9-3). The irrigation line trench was excavated mechanically and measured less than $20 \mathrm{~cm}$ wide, approximately $35 \mathrm{~cm}$ deep, and about $60 \mathrm{~m}$ long. On the northwest end of the irrigation line trench, beginning at where it connected to the tap trench and extending to where it intersected the "chill line" trench, topsoil increased in thickness from 15-20 cm to approximately 25 $\mathrm{cm}$. The "chill line" trench appears similar to a dirt road, and is the result of an extension of a main waterline from near the Student Recreation Center to a recently constructed building east of the current project area. Sediments exposed when the irrigation line trench intersected the "chill line" were different from those exposed in the remainder of the project area. These sediments were approximately $5 \mathrm{~cm}$ of yellowish, gravelly fill overlying very dark brown clay to depth in profile. The President's House groundskeeper, Becky Johnson-Camp, said that the "chill line" excavation was approximately $1.6 \mathrm{~m}$ wide and about $2 \mathrm{~m}$ deep.

The President's House groundskeeper picked up a single colorless glass bottle base fragment beside a pile of overburden near the terminal trench. It is not clear whether this glass shard came from the pile or from the surface nearby. Nonetheless, the piece had an unidentifiable maker's mark, no patination, what appeared to be a suction mark from an Owens Automatic bottle making machine, and contained within the glass a number of small bubbles $(<2 \mathrm{~mm}$ in diameter). From these clues, it can be deduced that the bottle fragment is from the mid-twentieth century (Lindsey 2010). However, with no secure context associated with it, the artifact can not be used to define or date any nearby archaeological 


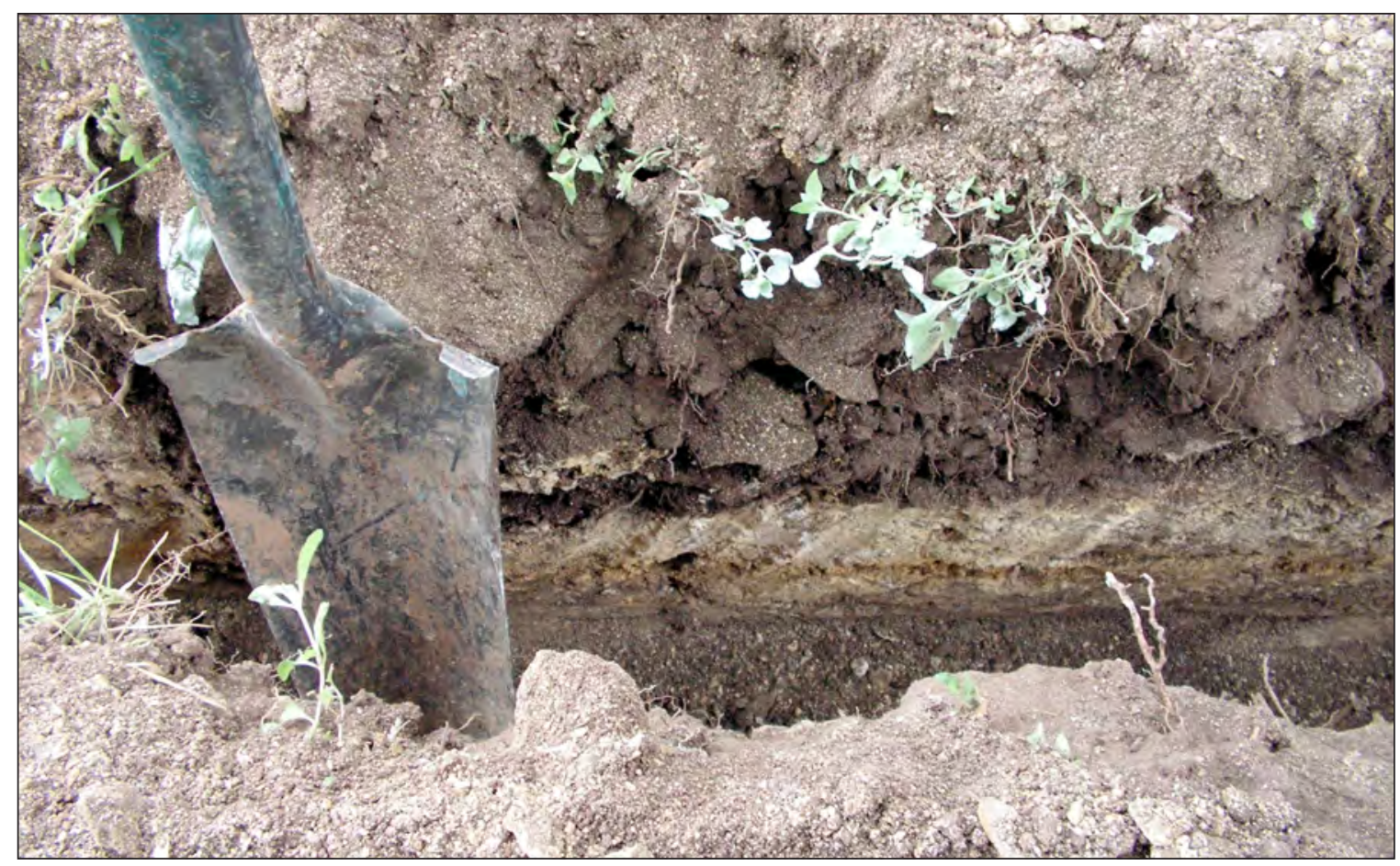

Figure 9-3. Trench profile.

deposits. In 2001, CAS archaeologists observed similar trench monitoring and recorded a small historic site, $41 \mathrm{HY} 318$, on the northern perimeter of the President's House (Jones 2003). Site 41HY318 represents the late nineteenth- to early twentieth-century home site of Albert S. Burleson, grandson of General Edward Burleson, and it also contains artifacts dating through the remainder of the twentieth century. The glass artifact observed during the current project could possibly be associated with a later component of 41HY318. However, the lack of context is problematic.

\section{Recommendations}

As no historic or prehistoric cultural materials were observed, no additional archaeological investigations were warranted or recommended. 


\title{
Chapter Ten
}

\section{Undergraduate Academic Center}

\author{
By Carole Leezer, David Yelacic, and Cinda Timperley
}

The University is constructing a new Undergraduate Academic Center (UAC) at 606 North Guadalupe Street, on the south edge of campus. After initially coordinating this proposed undertaking with the THC, the THC determined that archival research on this location was required prior to demolition and construction. Archival research conducted by Carole Leezer was submitted to the THC for review, and that agency recommended that the demolition and construction activities be periodically monitored by a professional archaeologist. Thus, this project proceeded in two phases. First, archival research was conducted on the proposed location to determine if any historically significant archaeological sites are likely to be present. Secondly, CAS archaeologist David Yelacic was present to monitor demolition and construction activities.

\section{Archival Research Results}

The proposed UAC is located at the end of North Guadalupe Street in San Marcos. The past address for this site (now University property) was 606 North Guadalupe Street, San Marcos, Texas. The site location is currently owned by the University and is used as a paved parking lot. A grass lawn area is located on the west side of the site. Jones Dining Hall borders the site to the southwest, Alkek Library borders on the northwest, Evans Liberal Arts Building lies to the north, and the Nueces Building is to the east. The parking lot was constructed in 1983 (Figure
10-1). The area where the current parking lot is now located includes Lots 5, 6, and 7 of Block 2 of the C. C. Mitchell Addition (Figure 10-2). Roanoke Road, also known as Frisco Street, was once located to the north of Block 2 of the C. C. Mitchell Addition.

The majority of Block 2 of the C. C. Mitchell Addition was once owned by the Roman Catholic Diocese of Austin (Figure 10-3). St. John the Evangelist (church building, hall, and rectory) was constructed on Lots 5, 6, and 7 of Block 2 in 1915. The parish began construction of a larger church at 624 E. Hopkins Street in San Marcos in 1969 and was dedicated in November of 1970. At this time, the previous St. John's property on North Guadalupe Street was divided. The larger portion, including the 1915 church building, a hall, and rectory, as well as two wood frame houses that were used since 1960 as the Catholic Student Center and Coffee House, was sold to the University on March 19, 1970 (HCDR 262/787). A few months later, on July 3, 1970, the church building was irreparably damaged in a fire and was subsequently demolished. The smaller portion of the church's property (Lots $8,9,10 ; 600$ N. Guadalupe Street), including a 1926 brick building that had served as a school and convent, was retained by the church. The St. John's parish school was run for many years by the Salesian Sisters. A new school was not built at the new church site on Hopkins Street, and the era of St. John's school ended in 1970. The 1926 brick building became the new Catholic Student 


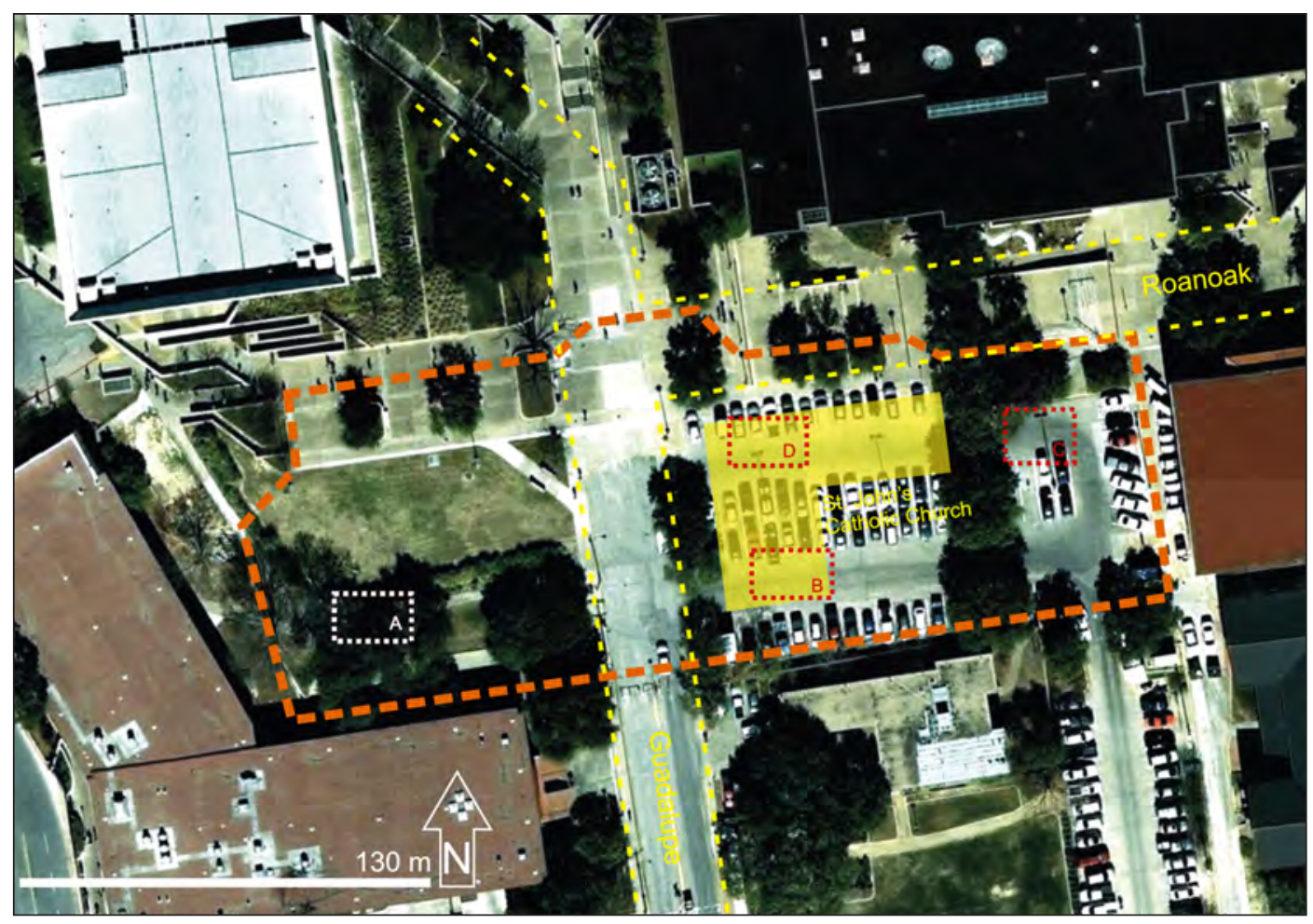

Figure 10-1. Aerial photo with approximate proposed construction boundary in red.

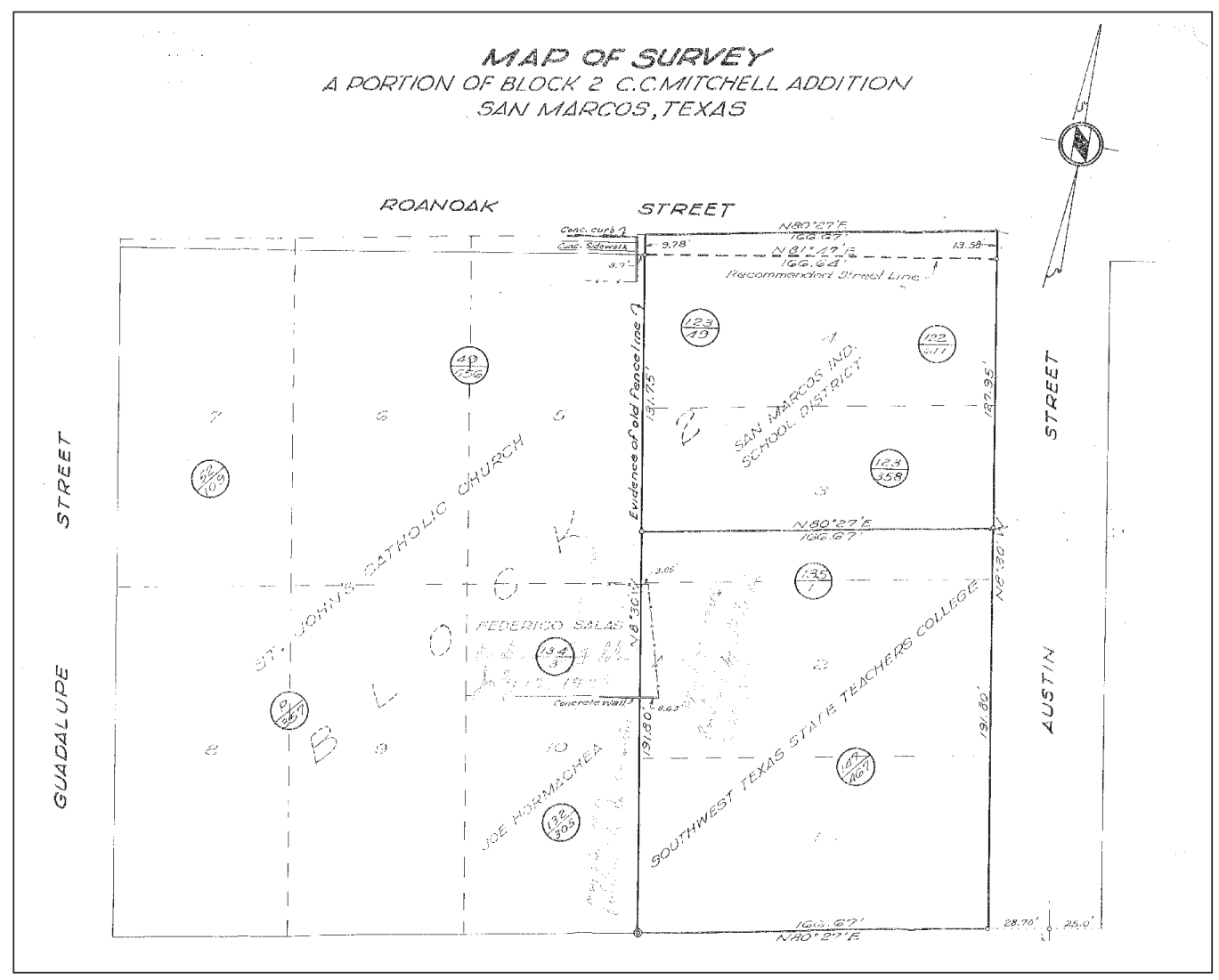

Figure 10-2. 1970 Plat map of Block 2, C. C. Mitchell Addition. 


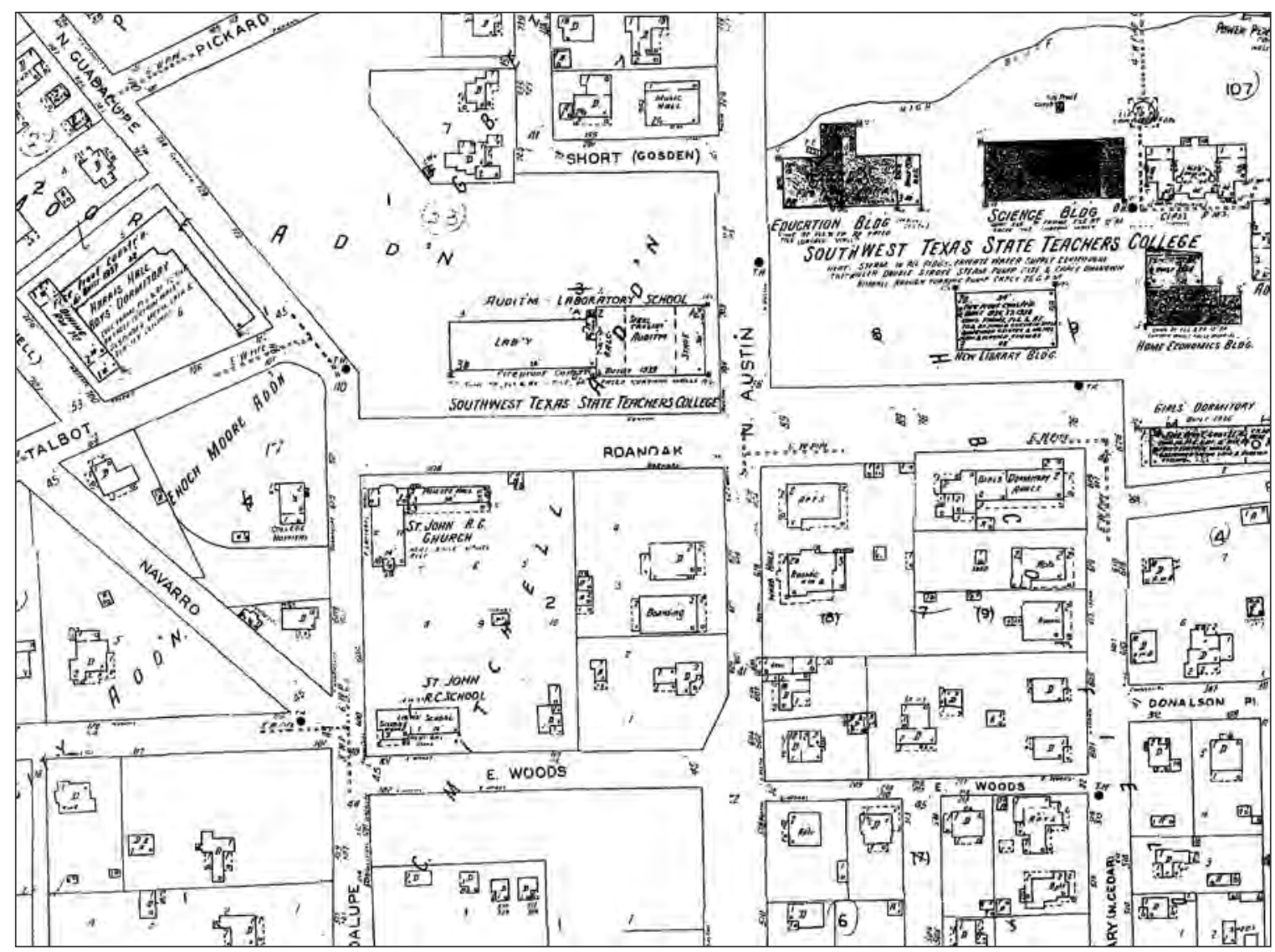

Figure 10-3. 1944 Sanborn map.

Center in June 1970 and remained the home of the Catholic campus ministry until the current structure was built on Concho Street in 1993. Lots 8,9 , and 10 were eventually sold to the University in 1992 (HCDR 929/98) in exchange for land the University owned at 100 Concho Street, upon which the parish constructed the new Catholic Student Center in 1993 (Niehaus 2008).

The City of San Marcos was founded in the 1840s. Block 2 (including Lots 5, 6, 7, 8, 9, and 10) of the C. C. Mitchell Addition was plated in June of 1868 (HCDR E/505) out of the Juan Veramendi land grant. Juan Martín de Veramendi was the Mexican governor of Coahuila and Texas between 1832 and 1833. He received a grant of 11 leagues in 1827. The town center was laid out on 640 acres of the land grant in 1851. The first Catholic chapel in San Marcos was dedicated on April 29, 1883, on the northeast corner of Guadalupe and Wood Streets (Lots 8 and 9) to serve Spanish-speaking residents in the area (Figure 10-4). The Catholic priest who visited San Marcos and built the church was Fr. Luis Morandi, an Italian. The parish was then known as Our Lady of Guadalupe and was assigned a permanent pastor in 1892 . In 1905 , the parish was handed over to the Missionary Sons of the Immaculate Heart of Mary, also known as the Claretians. At this time, the Claretians were new to Texas and to the United States. The Claretains were founded by a well-known Spanish bishop, Fr. Anthony Maria Claret (1807-1870, canonized 1950). He founded the Claretains in Spain in 1849. The congregation's first house in the United States was opened in 1902 in San Antonio, Texas. The San Marcos parish was their second settlement in the United States (Niehaus 2008). 


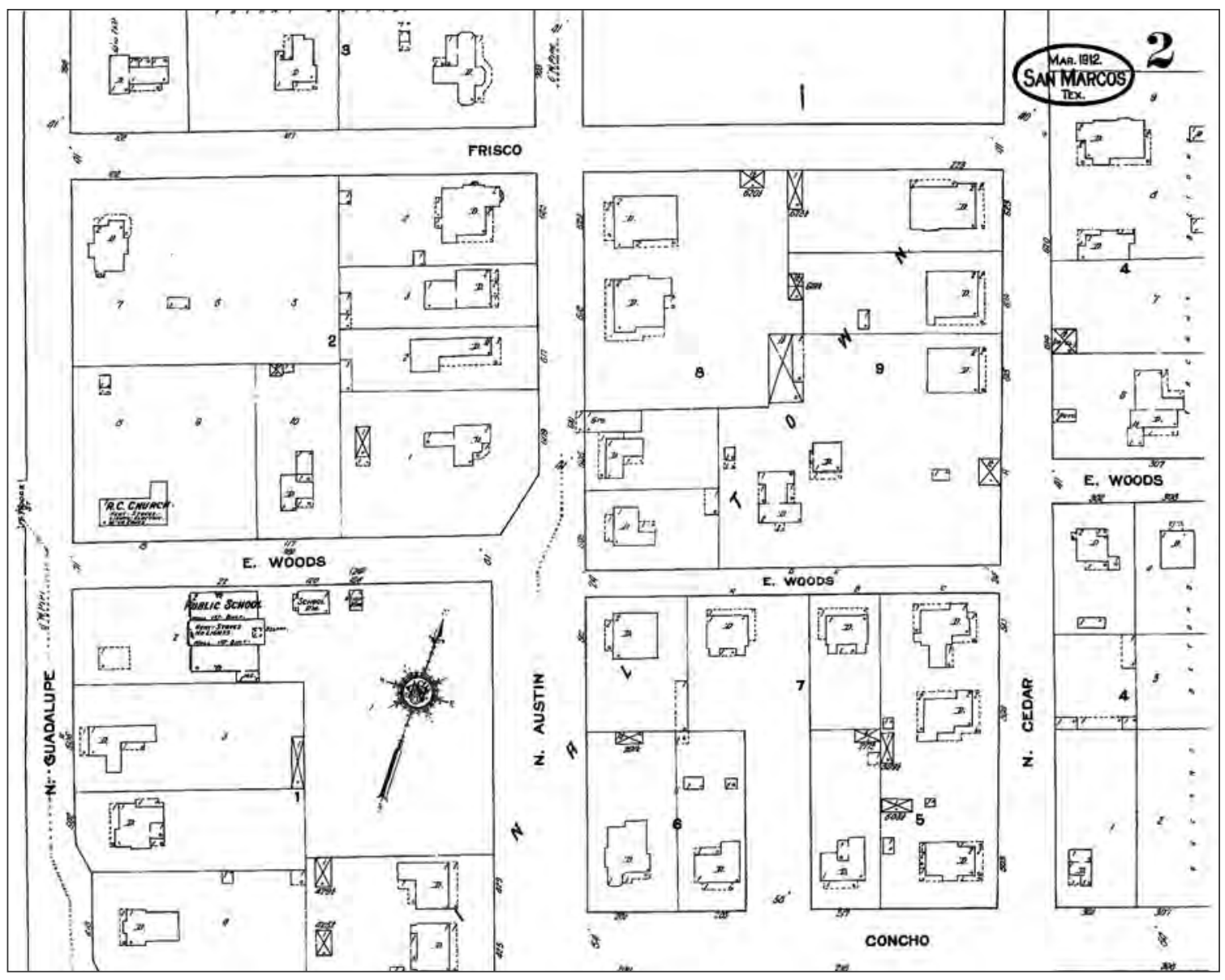

Figure 10-4. 1912 Sanborn map.

In 1915, a new church building and rectory was erected on Lots 5, 6, and 7 (Figure 10-5). The building of a new church had long been the wish of the Claretians, but cost and other obstacles kept it from becoming a reality. Building a new church was important to the community, as they felt that the old wooden building reflected badly upon the church. The Claretains were unable to secure funding due to the war in Europe and the Mexican Revolution. This all was resolved by an "unfortunate accident." On April 4, 1915, a fire broke out at the old wooden church, reducing it to ruin in less than thirty minutes. Construction on the new building soon followed on December 6, 1915, on Lots 5, 6, and 7 of the C. C. Mitchell Addition. The new building's construction was described as a "stately Romanesque Style. Occupying, as it does, one of San Marcos' beautiful hills and looking down and over the city, already tall, [the] building presents a most dignified example of ecclesiastical art: repose and strength are expressed in the towering edifice" (Niehaus 2008:40).

It was during the dedication of the new church buildings that the parish changed its name. In an article in the Southern Messenger on the cornerstone-laying, the parish is called St. John's the Evangelist for the first time (Southern Messenger [SM] 21 October 1915:1). No reason is given for the name change, but is seems that it might have been an effort to overcome the misconception that the parish was for "Mexicans" only. Prior to the construction of the new church in 1915, mass was conducted in Latin followed 


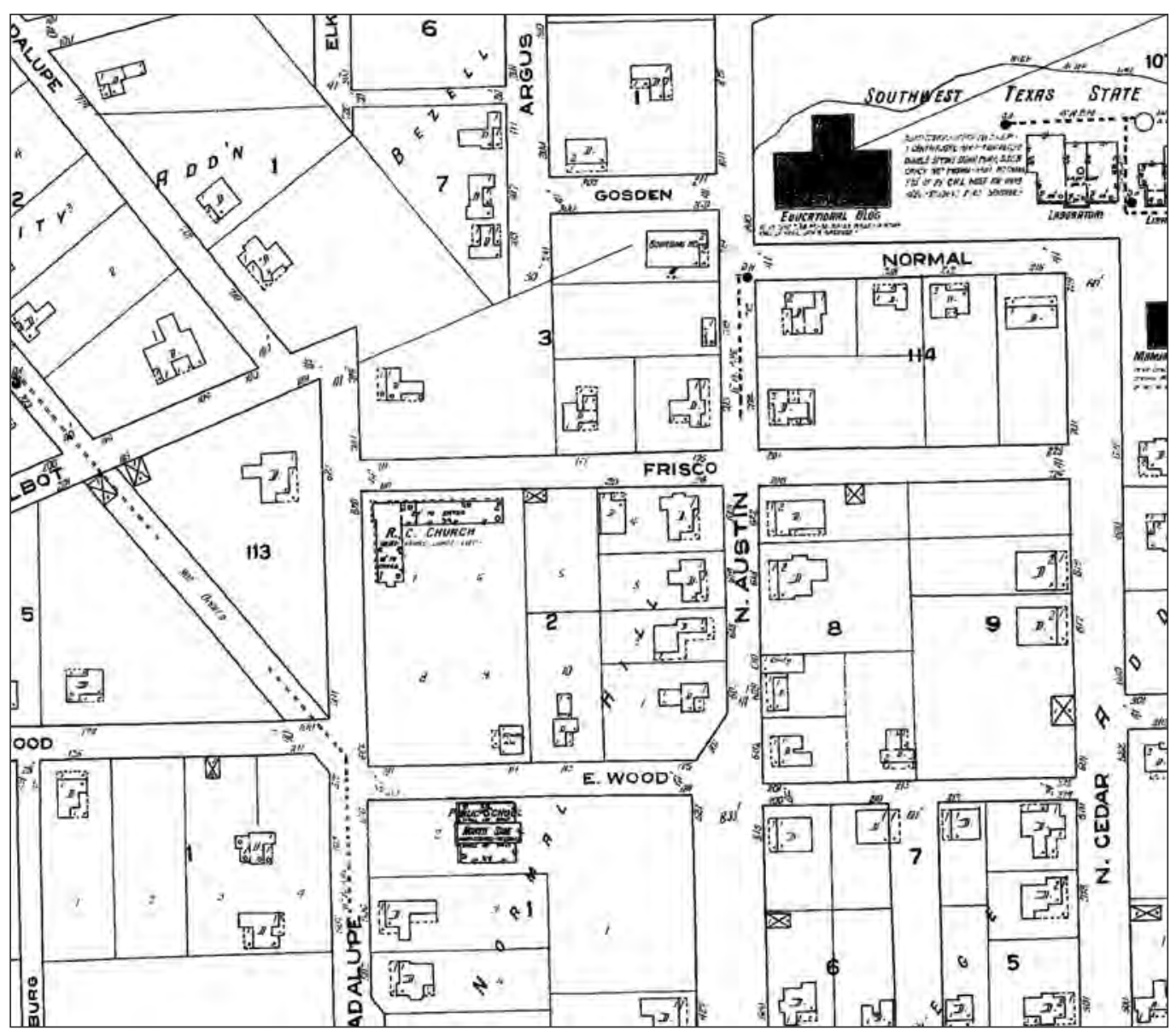

Figure 10-5. 1922 Sanborn map.

by a sermon in Spanish. Again, an article in the Southern Messenger addressed this issue:

The new church will be for the use of the few English-speaking Catholics residing here, the students attending the State Normal School, as well as the large Spanish-speaking congregation. Strange to say, notwithstanding the efforts of our pastor there seems to be some reluctance among a few of the students in coming to Mass, a fact which is likely due to the usual reply most of them get on inquiring about the Catholic church - the reply being "Oh, San Marcos has only a Mexican church over on the hill" [SM 21 October 1915:2].

The founding of the Newman Club (a University Catholic Student Organization) in
1914 appears to be an attempt at the integration of English-speaking Catholic students with the San Marcos parish. Not only did these new buildings serve the Catholic community of San Marcos, both Anglo and Mexican, but was also served as the location of the Newman Club for the next 45 years (Niehaus 2008).

As the University grew, the campus encroached upon the parish, surrounding St. John's on three sides. With campus growth, more Catholic students attended the University, and the parish took steps to give the Newman Club a new home. In 1960, the parish received a gift of an adjacent property (Lot 10; see Figure 10-3) with two houses that belonged to Joe Hormachea and his wife Mary (HCDR 181/77-81). The house that was closest to the church was designated as the 


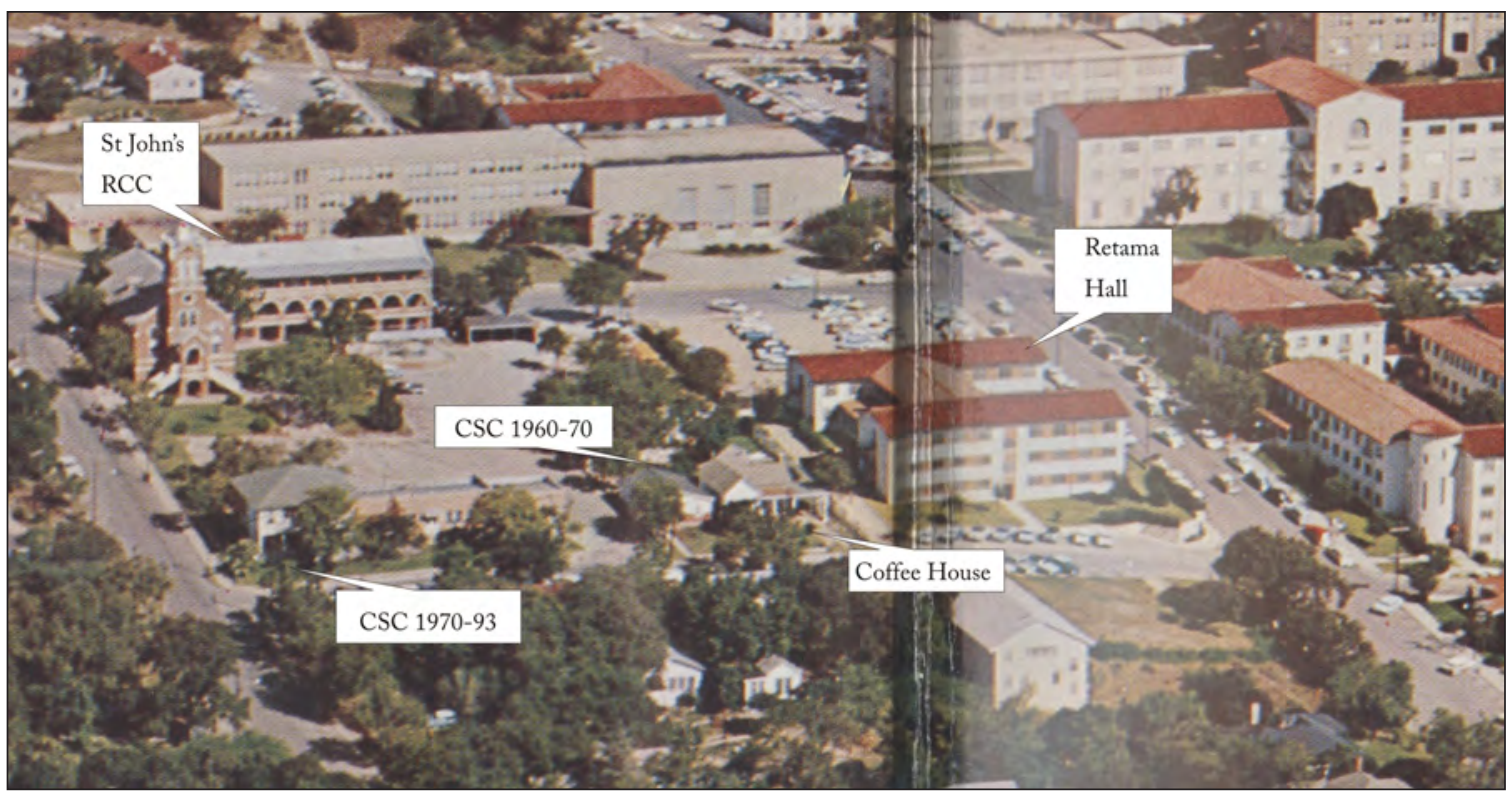

Figure 10-6. Aerial photo from 1961 Pedagog.

first Catholic Student Center (CSC) or Newman Center. The location of this house is now a parking lot, next to Retama Hall (see Figure 101). In 1970, the CSC relocated from the woodframed house on Wood Street to the adjacent school/convent building on the corner of Wood and Guadalupe (Figure 10-6). This relocation coincided with the sale of the property upon which St. John's church stood to the University, and the subsequent move of the parish to Hopkins Street. In 1993, the property where the CSC stood was eventually sold to the University, and a new CSC was constructed on Concho Street (HCDR 929/98).

\section{Archaeological Monitoring}

The current project involves removal of the modern parking lot in the eastern portion of the project area and subsurface excavations for associated infrastructure for the new UAC building. Removal of the parking lot and rerouting and replacing utility lines were the first component of the project. Though intrusive, these actions had no perceivable impact on previously undisturbed sediment; the new lines followed footprints of existing lines. Linear excavations associated with utility lines were no more than $2 \mathrm{~m}$ in diameter, ranged from 10 to $80 \mathrm{~m}$ in length, and reached as deep as approximately 4 $\mathrm{m}$ below surface, and were conducted well into bedrock. These excavations have no likelihood to impact any archaeological deposits that may be present. However, excavations for the basement and foundation of the new building, as well as a large trench that would be used as a tunnel connecting the two parts of the building, will potentially impact cultural deposits. The large block measures approximately $70 \times 140 \mathrm{~m}$ and is to be graded from surface in the southeastern corner to approximately $4 \mathrm{~m}$ below surface in the northwestern corner. The large trench/tunnel measures approximately $5 \mathrm{~m}$ wide, $4 \mathrm{~m}$ deep, and $75 \mathrm{~m}$ long. These excavations were concentrated in the eastern portion of the project area, whereas the utility line trenches were primarily located in the central and western portions of the project area. 


\section{Cultural Materials Encountered}

Despite excavation methods, specifically including the use of heavy machinery, being swift and highly intrusive, artifacts were encountered and occasionally observed in situ. In the southwestern corner of the project area, a number of red, machine-made bricks with SECO imprints (Figure 10-7) were found approximately $1 \mathrm{~m}$ below the surface, beneath a retaining wall foundation, at the junction of two waterline trenches. This cluster is labeled Area A on the project area map (see Figure 10-1). In addition to bricks, there was highly oxidized metal that appeared to have once been barrel hoops. In the southwestern, northeastern, and northwestern corners of the basement excavation pit, clusters of buried cultural materials included bricks, metal, glass, ceramic, and plastic. Items within these clusters had no discernable patterning, and all materials come from the early to mid-twentieth century. Additionally, all of these artifacts were recovered from a zone that varied in thickness and depth below surface and were capped by engineered fill and underlain by sterile sediments and bedrock. This cultural material-bearing stratum consisted of dark brown clayey loam sediment that was stark in contrast to the strata above and below. In addition to historic cultural remains, a single chert flake fragment with evidence of edge modification was recovered. This artifact lacked provenience. A representative sample of all observed artifacts was collected and listed below (Table 10-1).

Faunal remains consist of four bones from a juvenile individual that compares favorably to Canis sp. (Figure 10-8). Two elements are the left and right tibiae. One element is a partial left innominate with pubis and ischium. The fourth

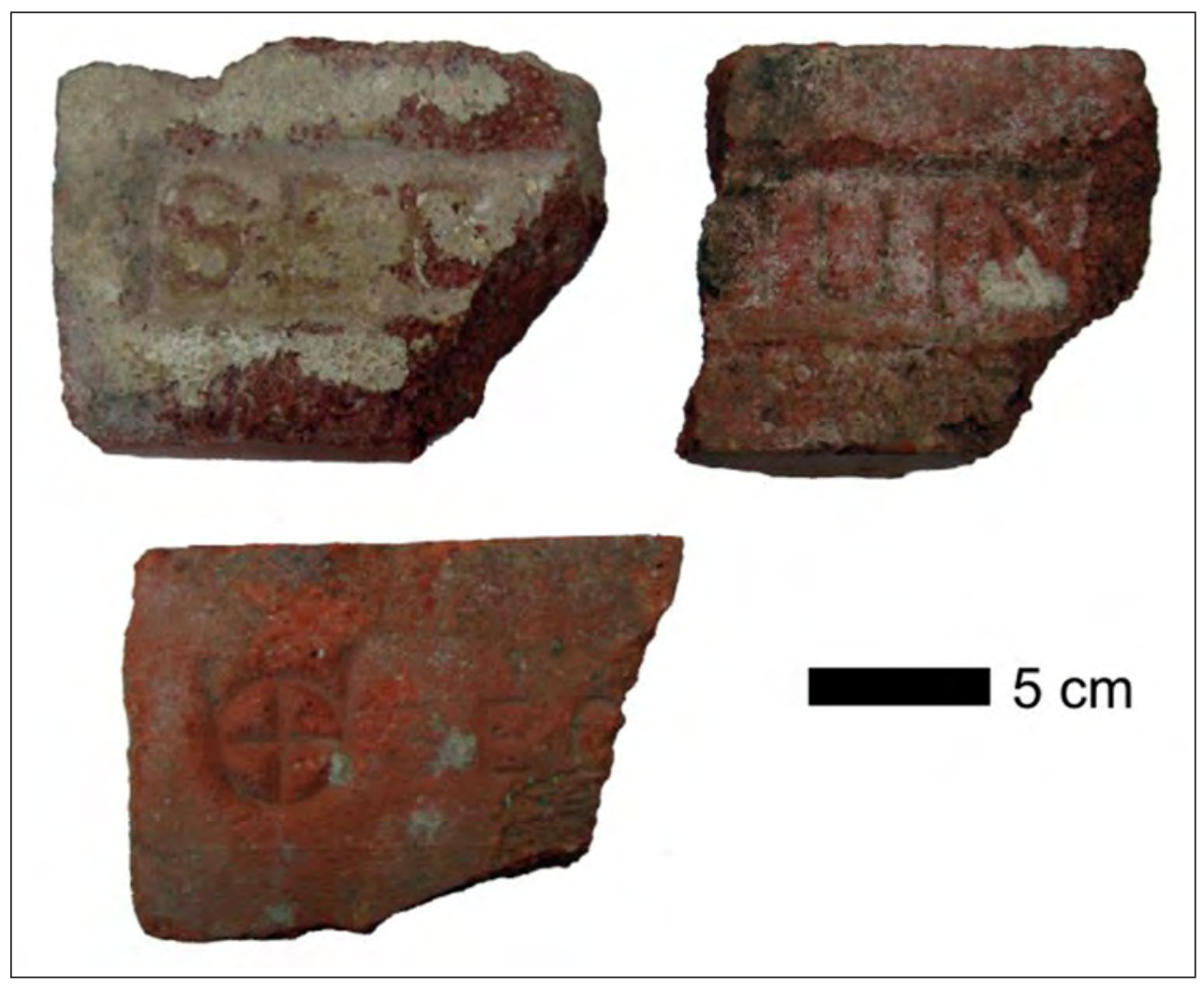

Figure 10-7. Bricks recovered during monitoring. 
Table 10-1. Artifacts Recovered from Areas B, C, and D (see Figure 10-1).

\begin{tabular}{ccccc}
\hline Artifact Class & Type & Description & Qty. & Wt. (g) \\
\hline building material & brick & "SEGUIN" & 3 & 3015.5 \\
building material & brick & "(?)ESBEC/(?)REDS" & 1 & 899.5 \\
building material & brick & machine-made with holes & 1 & 1692.5 \\
building material & brick & machine-made, yellow & 1 & 1131.5 \\
glass & vessel & aqua (ca. late 19th to early-mid 20th c.) & 3 & 34.4 \\
glass & vessel & colorless (ca. early 20th c.-present & 2 & 71.2 \\
glass & other & painted, colorless (ca. early 20th c.-present & 2 & 15.4 \\
glass & vessel & milkglass (ca. late 19th-mid 20th c.) & 1 & 35.4 \\
glass & vessel & red (ca. 20th c.) & 1 & 20.6 \\
ceramic & porcelain & no decoration one either, one flat and the other round & 2 & 16.5 \\
ceramic & stoneware & jug mouth sherd, Bennington/Rockingham glaze? & 1 & 127.9 \\
ceramic & stoneware & no decoration, plate sherds & 2 & 28.6 \\
ceramic & earthenware & no decoration, plate sherds & 1 & 3.2 \\
metal & tool & fork/spoon handle, "Rogers 1881" & 1 & 18.3 \\
bone & faunal & Canis sp. (see discussion below) & 4 & 15 \\
lithic & edge-modified & no platform, bifacial modification but most of virgin & 1 & 3.7 \\
\hline
\end{tabular}

element is the distal portion of the right radius. The cortical surfaces generally exhibit slight root etching. The surface is light brown with dark brown to brown-black staining. Weathering is minimal. There is no evidence of scavenging or of butchering. Taken all together, based on relative size and taphonomy, these elements likely belong to one individual.

\section{Radius}

The right radius lacks the proximal end. This is marked with a fresh break. The distal epiphysis is unfused and missing. Epiphyseal fusion surfaces is not damaged.

\section{Tibiae}

The left tibia is complete but for a small abrasion near the proximal articulation. A fresh gouge occurs on the lateral surface near the distal end. This specimen lacks both the proximal and distal epiphyses. Epiphyseal fusion surfaces are not damaged.

The right tibia is lacking the distal end, marked by a fresh break. The proximal epiphysis is unfused and missing. A small abrasion occurs near the proximal articular surface. Epiphyseal fusion surfaces are not damaged. Size comparison of the two tibiae suggests they are from the same individual. 


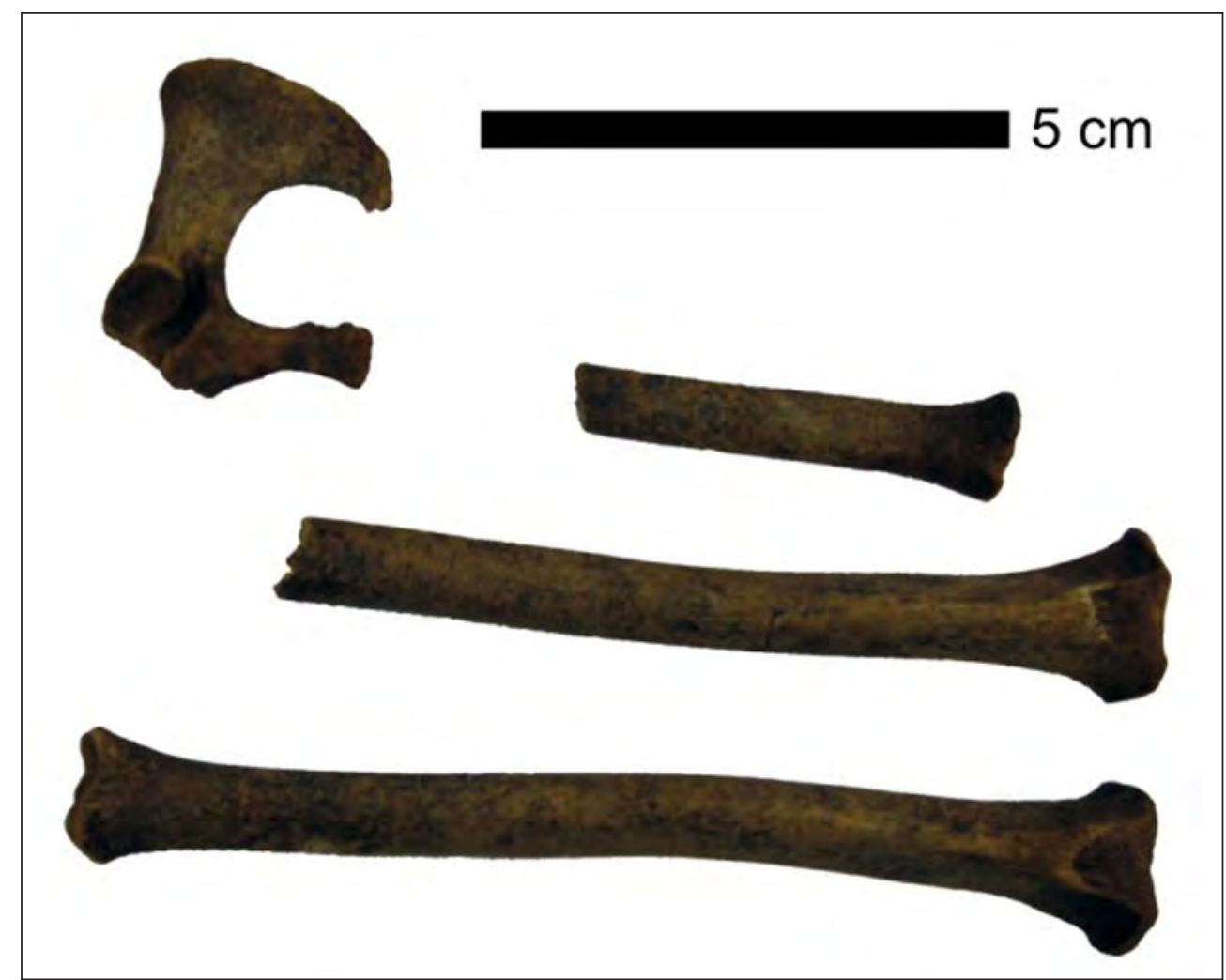

Figure 10-8. Faunal remains Canis sp.

\section{Innominate}

The left innominate lacks the ilium, but otherwise is complete. This element is broken along the anterior margin of the acetabulum, marked by a fresh break. The surface of the pubic symphysis is rugose, suggesting the pelvis was not fused.

\section{Conclusions}

During the mechanical excavation for the new UAC infrastructure, the remains of San Marcos' former Catholic Church, St. John's, were encountered. These remains had been considerably disturbed prior to the current undertaking as a result of the construction of parking lots and other activities in this immediate area. After moving to this location from just south of the project area, St. John's burned down and was completely demolished by the middle of the twentieth century. Accordingly, the artifacts encountered were scattered without discernable patterning or depositional integrity. In any event, no significant and intact remains were encountered, and therefore CAS recommends that the project area is not eligible for nomination to the NRHP or for listing as an SAL. 


\section{Chapter Eleven}

\section{Performing Arts Center Complex}

By Antonio Padilla, David Yelacic, Carole Leezer, and Jacob Hooge

The University is planning to construct a Performing Arts Center Complex (PAC) on the San Marcos Campus (see Figure 1-1). The complex consists of a Recital Hall, University Drive Parking Garage, South Chill Plant, roads, and associated landscaping. CAS conducted an archival review of the property to identify any possible historic events or persons of notable importance. Additionally, archaeological assessment was conducted, consisting of the excavation of 10 backhoe trenches across the project area.

\section{Archival Research}

The site is currently completely owned and controlled by the University (Figure 111). The proposed location for the PAC building and associated landscaping is within the block defined by University Boulevard, Moon Street, old demolished Concho Street, and Edward Gary Street (Figure 11-2). Construction of the PAC building and landscaping will involve the demolition of Falls Hall dormitory and the removal of the Butler Hall dormitory parking

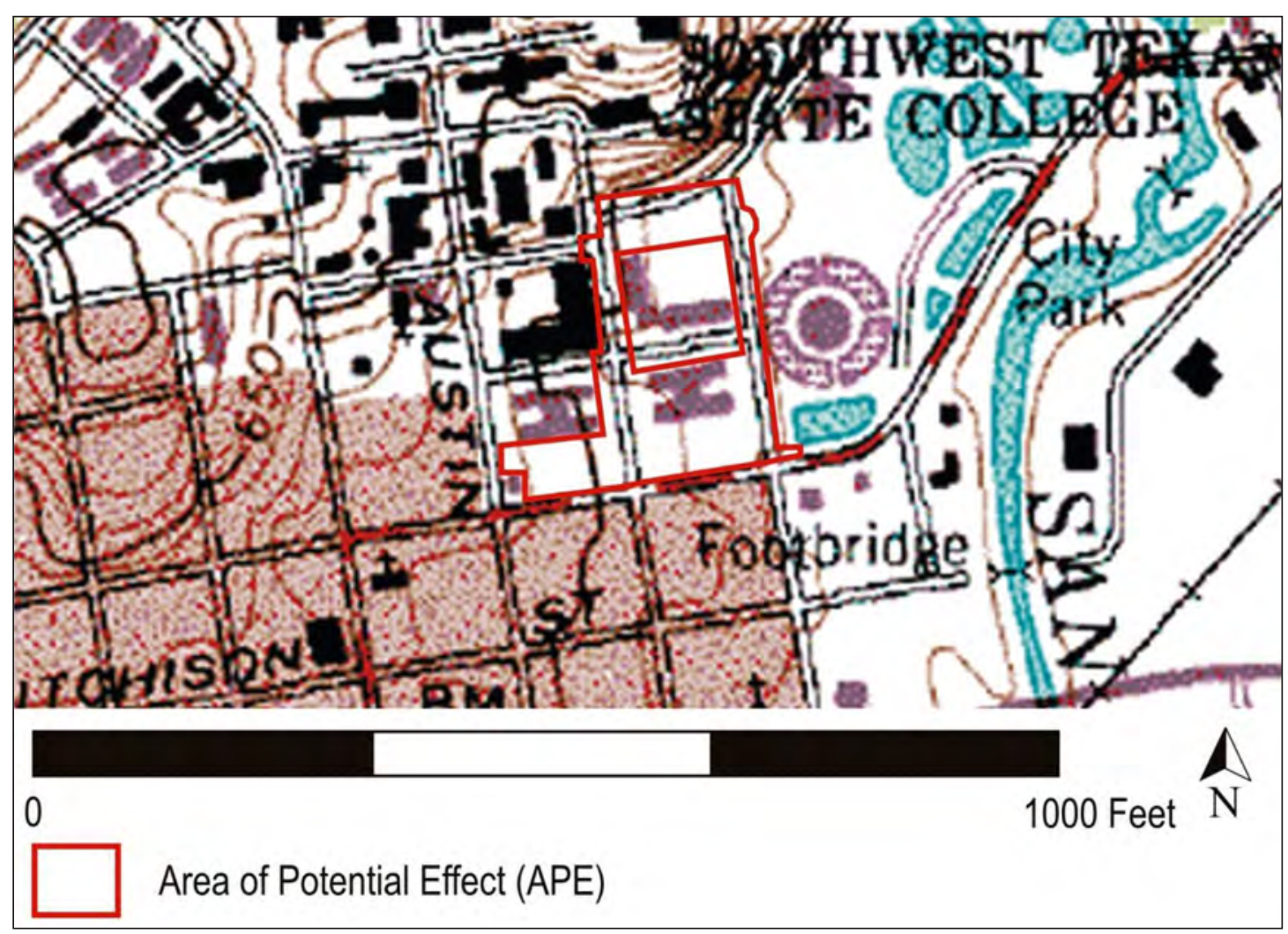

Figure 11-1. Project APE (red line) located on San Marcos North USGS quadrangle map. 


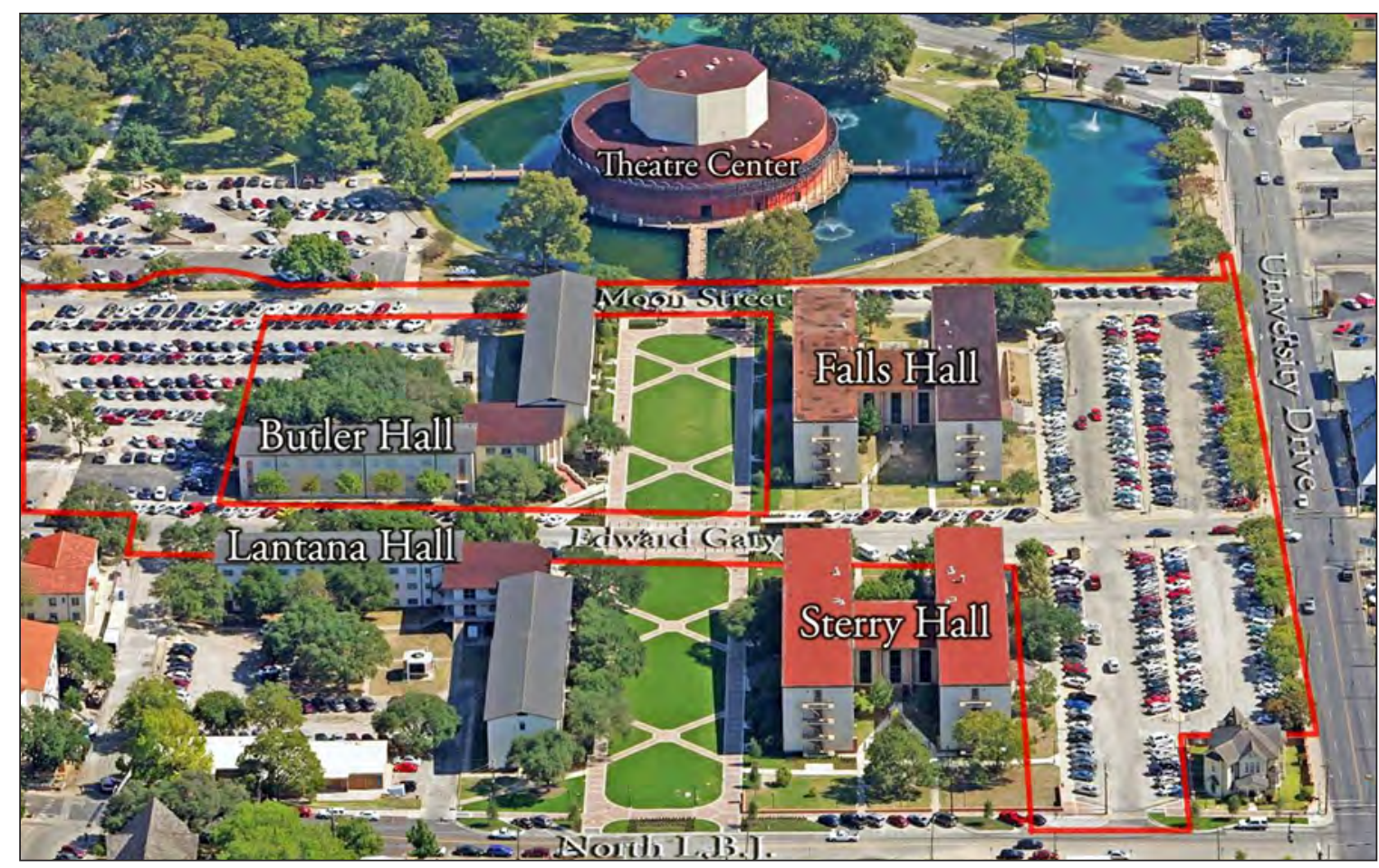

Figure 11-2. Performing Arts Complex APE within red lined area.

lot. The Parking Garage building site is bound by University Boulevard, Edward Gary Street, N. LBJ Street, and the existing Sterry Hall dormitory. The Sterry Hall parking lot will be removed during construction (Figure 11-3). Moon Street, Edward Gary Street, and Wood Street will be reconstructed, with new utilities installed.

As Falls Hall is slated for demolition as part of this project, a review of its design and construction was conducted. Falls Hall was built in 1965/66 during the University presidency of Dr. James H. McCrocklin. In June 1965, the Board of Regents entered into a contract with General Contractor J. C. Evans Construction Company of Austin, Texas, for the construction of a women's (Falls Hall) and a men's dormitory in the amount of $\$ 2,307,200.00$. In September 1965, the Board of Regents hired architect Harvey P. Smith and Associates of San Antonio, Texas, to design Falls Hall and a men's dormitory, along with an addition to the Jones Dining Hall. By June 1966, work on the Falls Hall was completed. The women's dormitory received the name of Elizabeth Falls in memory of a professor of education.

A review of property deeds within the project area indicated that no persons of historical significance owned or lived on the properties that are part of the project area. The majority of the parcels upon which the proposed project is located were obtained by the University as part of the Urban Renewal program of 1964. The Urban Renewal Program was introduced by President Lyndon B. Johnson as part of his package of reforms known as the "Great Society."

A review of historic sites near the project area identified a National Register Property, the Hutchinson House (Figure 11-4), located on the northeast corner of University Drive and North LBJ Drive, adjacent to the project area. The Hutchinson House was originally located just north of its current location, and was moved 1967 to avoid demolition by the Urban Renewal Program. The house was built in 1896 by architect 


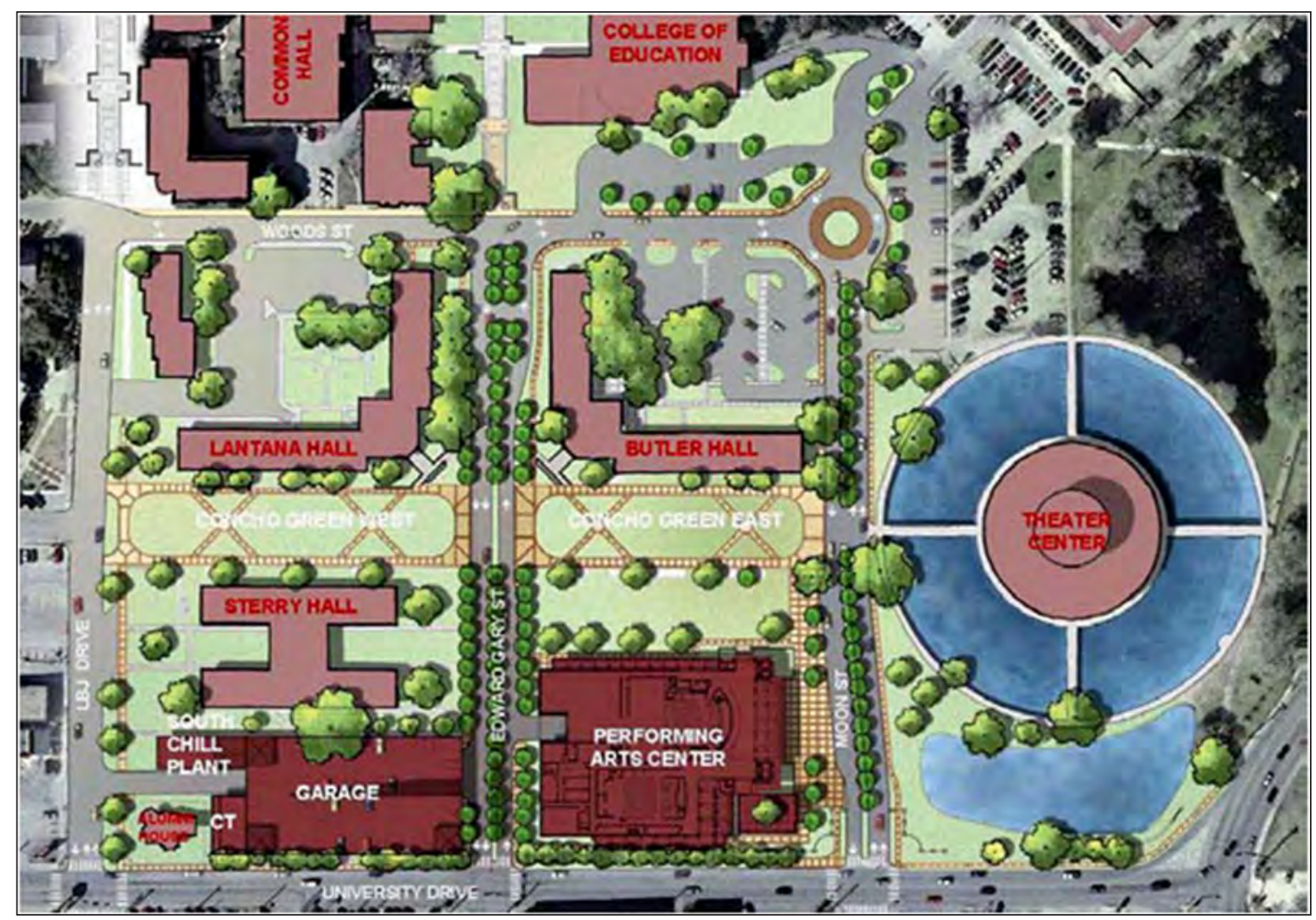

Figure 11-3. Overview of project location with proposed improvements.

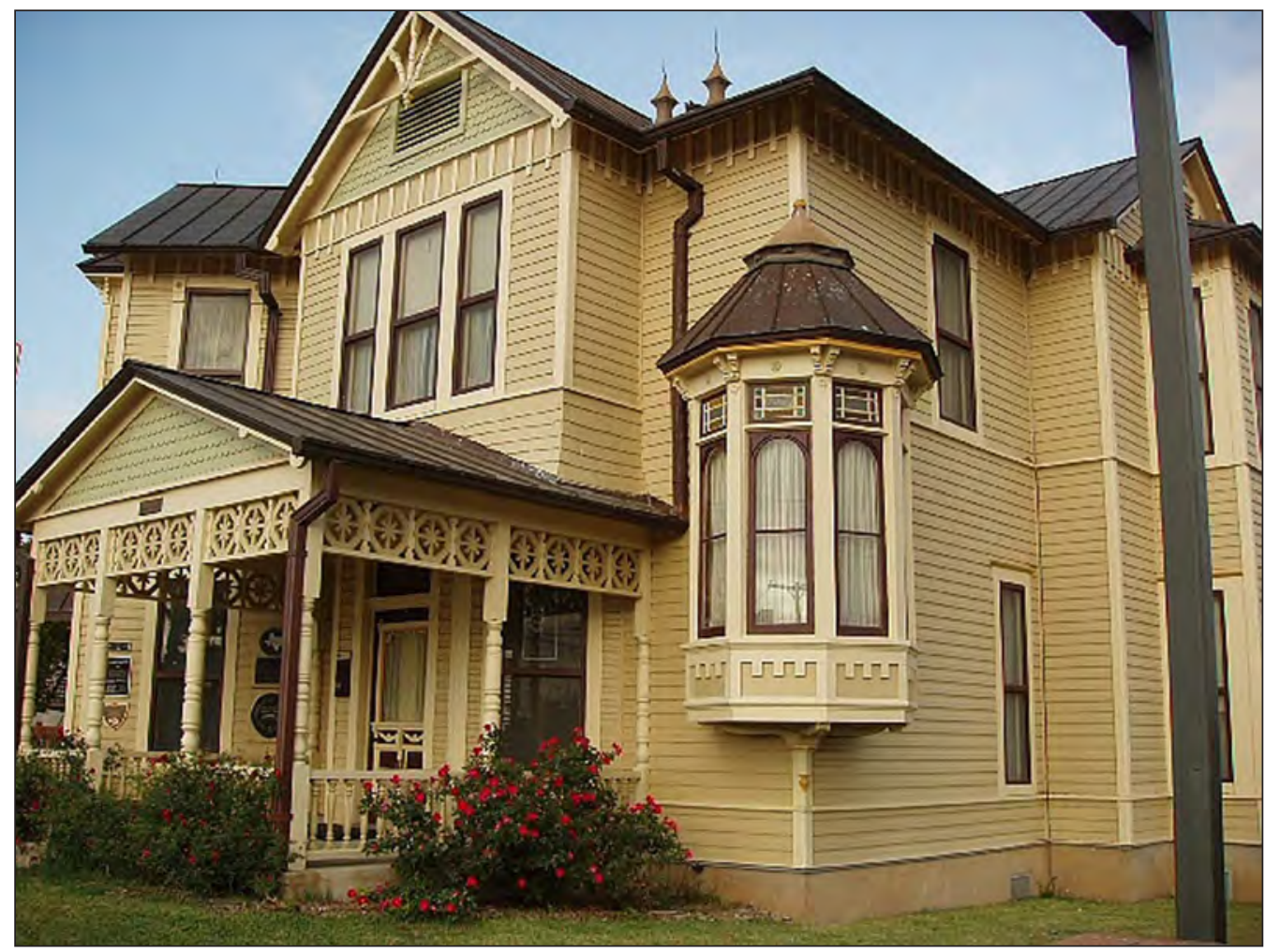

Figure 11-4. Hutchinson House. 
and contractor Charles S. Sinz and is an example of Victorian-period architecture. The house was designed and built for Beverly Hutchinson, son of Major W. O. Hutchinson, one of San Marcos's early developers. The Hutchinson family lived in the residence from 1896 until 1913, when they moved to Kyle. The house changed hands several times, but was regularly operated as a boarding house. President-to-be Lyndon B. Johnson took his meals here from March 1927 to September 1928 and during the summer of 1929. Some accounts claim that he also boarded here while a student at Southwest Texas Teachers College. Johnson revisited the house in 1964 . While this property is adjacent to the current project area, it will not be affected or impacted by the proposed construction.

\section{Archaeological Investigations}

The project area is located on an alluvial terrace of the San Marcos River and is immediately adjacent to SAL 41HY161. This location is considered to possess a high probability for deeply buried cultural resources, particularly deposits associated with 41HY161. In order to assess the project location for possible subsurface prehistoric cultural deposits, a series of 10 backhoe trenches were excavated.

\section{Methods}

Investigations were conducted on September 11,18 , and 25, 2010, and consisted of monitoring 10 backhoe trenches excavated by Myers Concrete of San Marcos, Texas. Investigations also included examining removed soils and exposed soil profiles. Three of the 10 trenches excavated were located in the parking lot of Sterry Hall, three were located in the parking lot of Falls Hall, and four were located in the parking lot of Butler Hall (Figure 11-5).

CAS archaeologists monitored the removal of sediment and identified cultural materials and deposits encountered throughout these excavations. Each trench measured

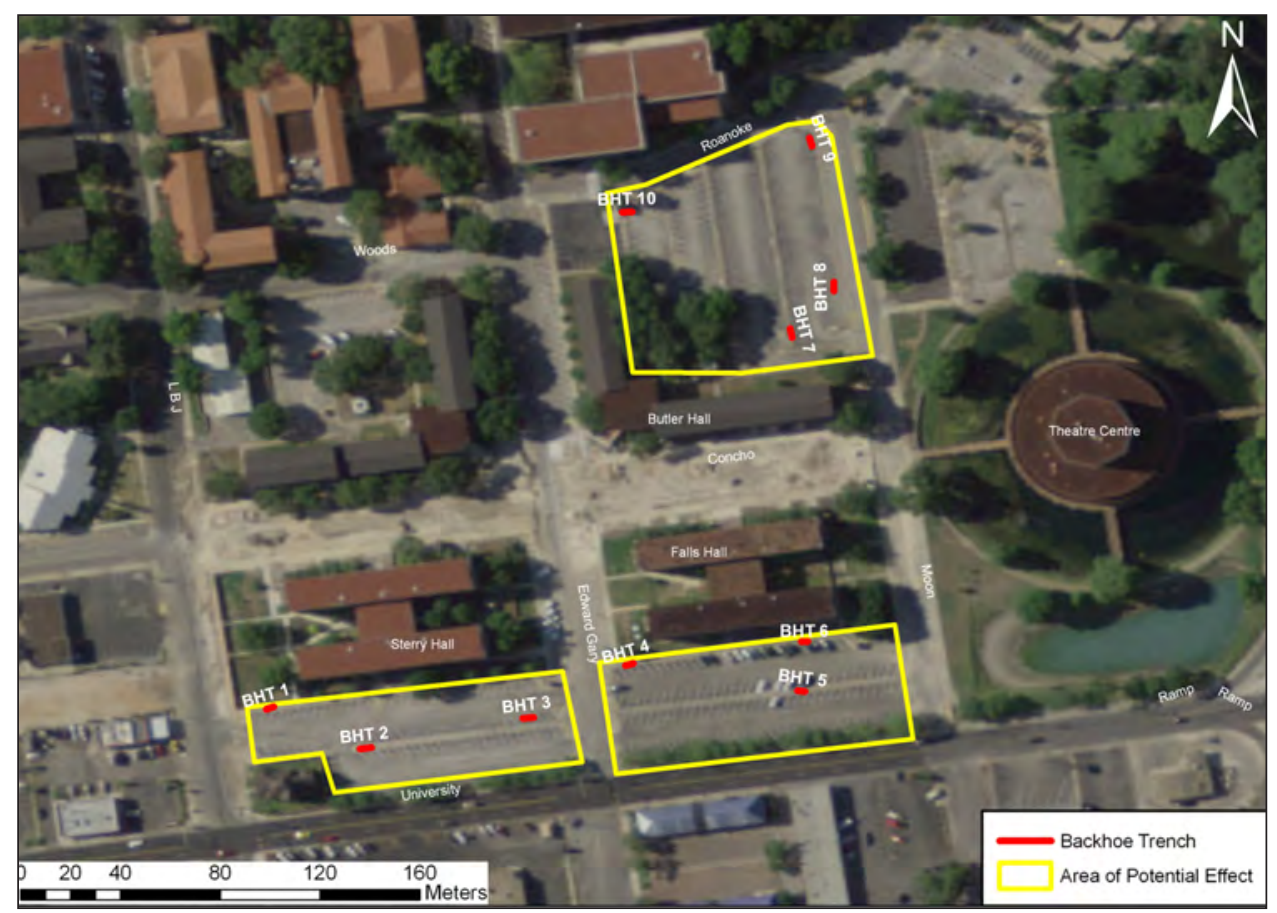

Figure 11-5. Backhoe trench locations within APE. 
approximately $10 \mathrm{ft}(3.04 \mathrm{~m})$ in length and $3.28 \mathrm{ft}(1 \mathrm{~m})$ in width. Trench depths across the APE ranged from 5.5 to $10 \mathrm{ft}(1.71 \mathrm{~m}$ to $3.04 \mathrm{~m})$ based on varying depths of sterile subsoils. All trenches deeper than $4 \mathrm{ft}(1.22 \mathrm{~m})$ were stepped to ensure safety. Excavations began with by removing asphalt paving and subsurface fill, and exposing intact underlying soils. Once these soils were exposed they were systematically removed in 12-inch (ca. $30 \mathrm{~cm}$ ) levels for vertical control. Sediments from each level were placed in separate piles, and archaeologists collected no fewer than five 5-gallon bucket samples of each level/sediment pile to be screened through $1 / 4$-inch mesh screen to recover any artifacts present. Once each trench was completed, trench wall profiles were recorded and samples were taken (Figure 11-6). The trench was then refilled with the excavated sediments.

\section{Results}

Excavation of the 10 trenches yielded a total of 53 artifacts from seven trenches (BHT 1, BHT 3, BHT 4, BHT 6, BHT 8, BHT 9, and BHT 10; Table 11-1). Of the 53 artifacts, 12 were prehistoric, while 41 are of historic and/ or modern in age. The historic and or modern materials were collected from the upper $2 \mathrm{ft}$ $(\sim 60 \mathrm{~cm})$ of the trenches, while the prehistoric materials encountered were located at depths ranging from 2 to $4 \mathrm{ft}(\sim 60$ to $120 \mathrm{~cm})$ below the surface. None of the historic materials collected were considered significant or contained agediagnostic characteristics. Prehistoric materials consisted of a small number of chert flakes and chips and a diagnostic Nolan-like projectile point from BHT 10 (Figure 11-7). No collected material was recovered from a discernable zone or clear cultural component. All cultural remains appeared thin and dispersed in character.

A Nolan-like projectile point (see Figure 11-7), dating to the Middle Archaic period

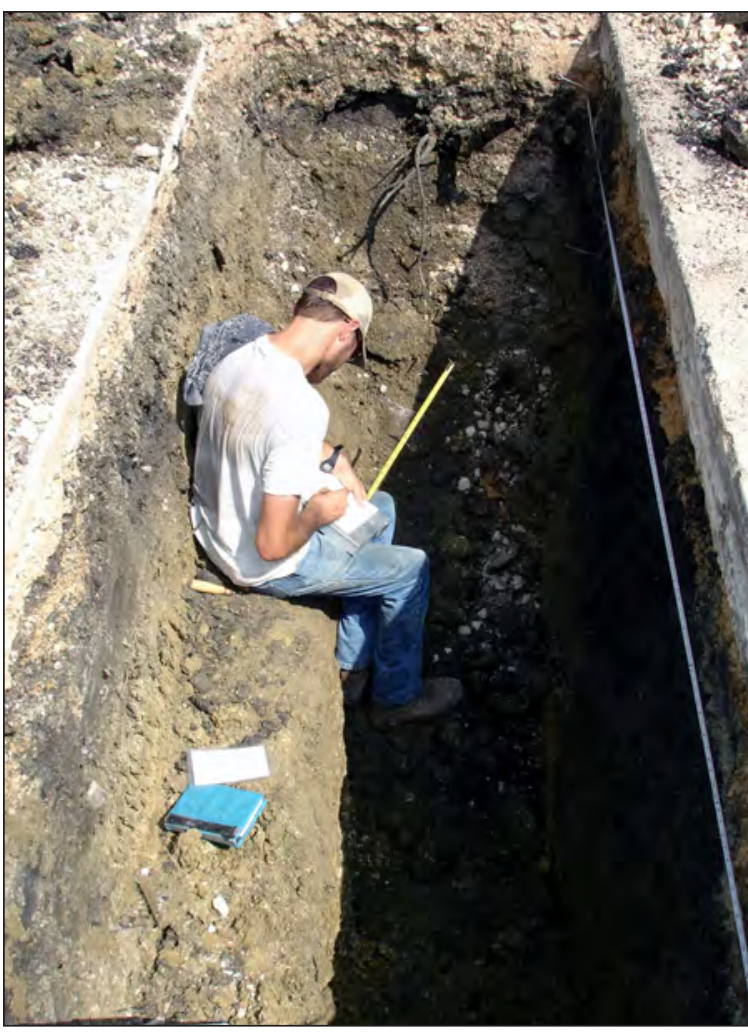

Figure 11-6. Archaeologist David Yelacic completing a trench wall profile.

(approximately 5800-4000 BP) was collected from BHT 10. It was located approximately 3-4 $\mathrm{ft}(92-124 \mathrm{~cm})$ below the surface in a colluvial matrix, a problematic depositional context for site integrity. In an effort to determine the integrity of the matrix and evaluate whether the point was from intact deposits or a mixed context, two sediment samples were collected and submitted for humate dating. The samples were taken at 90-95 and 120-125 cmbs, bracketing the approximate depth of the projectile point. Ideally, the two humate dates would approximately correlate with the expected age range for Nolan points, thereby showing the sediments here to be intact and of relative contextual integrity. Alternatively, if the dates prove to be unrelated to the Middle Archaic, they may indicate that the point was introduced into this deposit through disturbance or other processes, and that the deposits here lack cultural integrity. 
Table 11-1. Inventory of Artifacts Collected from all Backhoe Trenches.

\begin{tabular}{ccccc}
\hline BHT & $\begin{array}{c}\text { Depth } \\
\text { (ft) }\end{array}$ & $\begin{array}{c}\text { Depth } \\
\text { (cm) }\end{array}$ & $\begin{array}{c}\text { Artifact } \\
\text { Type }\end{array}$ & Count \\
\hline 1 & $2-3$ & $61-92$ & lithic & 3 \\
1 & $3-4$ & $92-124$ & lithic & 2 \\
3 & $1-2$ & $30-61$ & round nail & 2 \\
3 & $1-2$ & $30-61$ & metal & 1 \\
3 & $1-2$ & $30-61$ & clear glass & 11 \\
3 & $1-2$ & $30-61$ & blue glass & 1 \\
3 & $1-2$ & $30-61$ & brown glass & 1 \\
3 & $1-2$ & $30-61$ & frost glass & 1 \\
3 & $1-2$ & $30-61$ & modern ceramic & 1 \\
3 & $1-2$ & $30-61$ & whiteware & 1 \\
3 & $1-2$ & $30-61$ & charcoal & 13 \\
3 & $3-4$ & $92-124$ & lithic & 1 \\
4 & $3-4$ & $92-124$ & lithic & 1 \\
6 & $1-2$ & $30-61$ & brick & 9 \\
8 & $3-4$ & $92-124$ & lithic & 1 \\
9 & $3-4$ & $61-92$ & lithic & 1 \\
10 & $2-3$ & $92-124$ & lithic & 1 \\
10 & $3-4$ & $92-124$ & projectile point & 1 \\
10 & $3-4$ & $92-124$ & lithic & 1 \\
\hline & & & Total & 53 \\
\hline
\end{tabular}

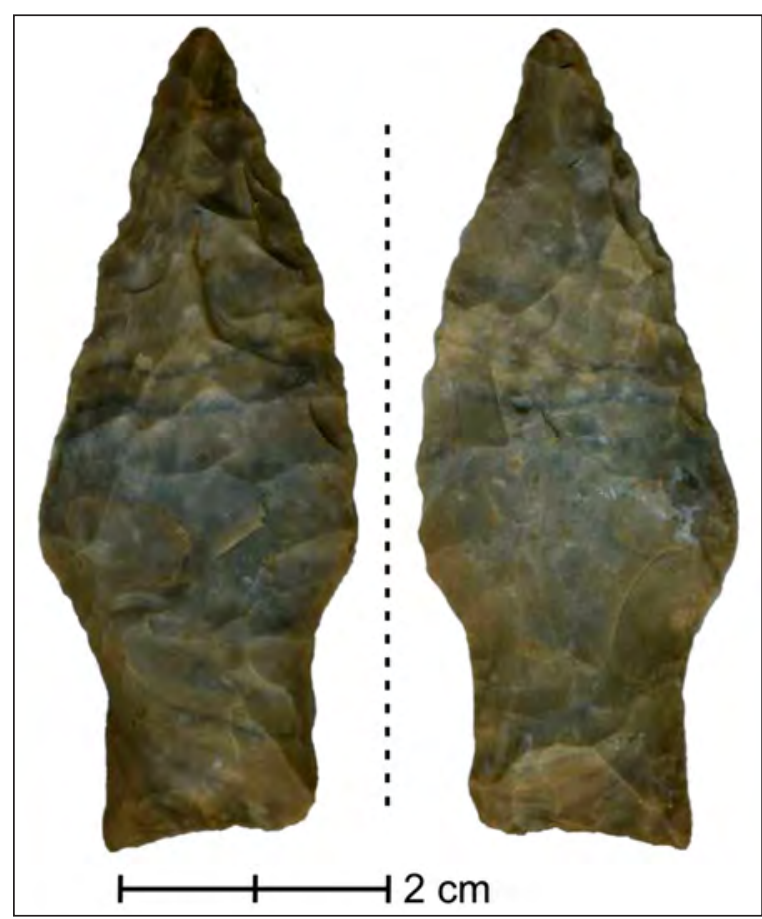

Figure 11-7. Nolan-like projectile point recovered from BHT 10; dorsal and ventral views.
The two humate samples were sent to Beta Analytical for dating and results were received by CAS on October 18, 2010. The two dates clearly showed that the sediments at this level were stratigraphically intact, with the date from Sample 1 ranging from 1270 to 1060 BP (AD 680 to 890 ), and the date from Sample 2 ranging from 2340 to $2140 \mathrm{BP}$ (390 to $90 \mathrm{BC}$ ). The first date from humate Sample 1 indicates that the soils within that zone date to the Late Prehistoric period, which is underlain by sediments from the Late Archaic as indicated by the date obtained from humate Sample 2 (Table 11-2).

Although the dates show stratigraphical integrity of the soils, the presence of the Nolan point within the zone is highly problematic in terms of contextual integrity of this deposit. The presence of this Middle Archaic point in association with Late Archaic to Late Prehistoric ages suggests that the point may have been deposited through noncultural means such as colluvial processes. Due to the location of BHT 10 near the base of a large hill, the point could have been deposited at the base of the hill as a result of downwash from a site on top of the hill. Because artifacts are constantly eroding from hilltop sites, artifacts are often displaced along the side-slopes and at the bases of hills and are found out of place with respect to their original depositional contexts. As a result, these artifacts lack contextual integrity. In the case of the Middle Archaic Nolan point located within Late Archaic-aged soils at the base of the hill, it seems highly probable that the point was deposited through colluvial processes.

\section{Summary of Geoarchaeological Observations}

Sediments and soils exposed during trench excavation were examined for their potential to contain intact archaeological deposits. In doing so, factors including depositional 
Table 11-2. Radiocarbon Dates from Humate Samples 1 and 2.

\begin{tabular}{cccccc}
\hline Sample & $\begin{array}{c}\text { Beta } \\
\text { No. }\end{array}$ & $\begin{array}{c}\text { Conventional } \\
{ }^{14} \text { C Age }\end{array}$ & $\begin{array}{c}\text { cal BP, } \\
\mathbf{2 \sigma}\end{array}$ & Context & Period \\
\hline Humate Sample 1 & 285762 & $1230 \pm 40$ & $1270-1060$ & $90-95 \mathrm{~cm}$ & Late Prehistoric \\
Humate Sample 2 & 285763 & $2230 \pm 40$ & $2340-2140$ & $120-125 \mathrm{~cm}$ & Late Archaic \\
\hline
\end{tabular}

environments and postdepositional perturbations were considered, as they contribute to and affect the integrity of cultural materials in sedimentary matrix. To systematically address these concerns and investigate the potential for these soils to contain archaeological materials, a combination of sedimentary geology and soil science methods were employed. In this practice, zone is the fundamental unit of measurement and observation. A zone consists of a distinct sedimentary stratum, soil horizon, cultural deposit, or any combination of the three as long as upper and lower boundaries are apparent. Characteristics such as color, texture, structure, percent of coarse fragments, pedofeatures and other inclusions, and lower boundary, were recorded for each zone (Appendix C). A synthesis and summary of observations is presented below.

The sample of excavations generally covers the entire APE, and provides reasonably complete coverage of areas thought to have a moderate-tohigh probability of containing cultural deposits (see Figure 11-5). The first three backhoe trenches (BHTs 1, 2, and 3), located in the Sterry Hall parking lot, were the farthest from the river (i.e., farthest to the west) and highest in elevation. BHT 1 was the westernmost excavation, and soils encountered exhibited A/Ap-Btk1-Btk2-Bt/C-C profile beneath a combined $37 \mathrm{~cm}$ of asphalt and construction fill. The A/Ap horizon extended from 37 to $72 \mathrm{cmbs}$ and contained mottles, likely associated with construction-associated mixing. The Btk1 horizon, extending from 72 to $102 \mathrm{cmbs}$, appeared intact and contained lithic debitage. The Btk2 horizon extended to
$115 \mathrm{cmbs}$ and also contained lithic debitage. The difference between these two horizons was carbonate morphology; in the upper, carbonates formed filaments, whereas in the lower they were both filamental and nodular in form. Both of these horizons, and those below, have integrity in terms of postdepositional disturbance, or the lack thereof. In other words, sediments encasing artifacts appeared intact, and therefore could potentially contain intact cultural deposits. Beneath the Btk horizons, there was mottling of parent material and the above pedogenically altered material. Secondary carbonates in the parent material exhibited features not common to archaeologically significant periods (i.e., crystalline structure). Approximately $30 \mathrm{~m}$ west-southwest of BHT 1, BHT 2 exhibited a similar, albeit shallower, soil profile. No cultural material was observed within BHT 2. However, nonconstruction fill sediments appeared intact and could be thought of as containing the same potential of preserving intact cultural deposits as BHT 1.

BHT 3 was located in the far eastern portion of the Sterry Hall parking lot, just west of S. Edward Gary Street. Sediments encountered in this backhoe trench were markedly different than any others encountered during the project. These sediments were dominated by historic/modern fill, most likely associated with the gas station that formerly occupied this location, overlying a $\mathrm{C}$ horizon. The historic/modern fill reeked of petroleum, and it had a slightly greenish tint. Fortuitously, a nearby gas station was removing gasoline storage tanks, and provided 
CAS archaeologists with the opportunity to observe the fill associated with such features. Observation of the nearby gas station confirmed field interpretations. Odors emitting from the sediments and matrix surrounding the tanks were pungent and soils had a greenish tint. Archaeologically significant sediments, if ever present, are no longer in the footprint of the gas station that once shared the same location as BHT 3.

Farther to the east, the next three backhoe trenches were excavated in the parking lot of Falls Hall. BHT 4 contained a combination of cement/ asphalt and associated construction fill from the surface to a depth of $28 \mathrm{cmbs}$. Beneath this modern fill was a historic/modern disturbed A/ Ap horizon extending to $124 \mathrm{cmbs}$. This horizon was very wet and contained mottles, common clay coats on gravels, two concrete inclusions, and artifacts representing prehistoric and historic times. Mottled sediments, similar to those in BHT 1, were likely the result of construction activity, whereas the common clay coats resulted from the apparently high soil moisture. A piece of lithic debitage, recovered from sediment located at 92 $124 \mathrm{cmbs}$, represents a prehistoric component. A sherd of historic stoneware was observed at approximately $70 \mathrm{cmbs}$. These cultural materials, however, were both located within sediment that appeared to lack integrity. Beneath the A/Ap horizon, there was a relatively thin Bt horizon (124-145 cmbs) overlying parent material. Though these subsoils appeared intact, their age was likely greater than what is considered archaeologically significant. They were not, however, as old as the subsoils observed in BHTs 1 and 2.

In BHT 5, an A/Ap-Bt-Bk/C soil profile was buried beneath $21 \mathrm{~cm}$ of asphalt and construction fill. The A/Ap horizon contained manufactured wood fragments and round nails, both of modern age. Beneath this horizon, the Bt horizon exhibited features representing a high shrinkswell capacity of the clays (e.g., slickensides), and at the base of the profile was a $\mathrm{Bk} / \mathrm{C}$ with nodular and filamental carbonate morphology. No cultural materials aside from the modern debris were observed. If cultural materials were to be contained within the sediments showing signs of shrink-swell processes, the artifacts would have the potential to move slightly throughout the profile, and thus, the potential to contain intact cultural deposits is relatively low. BHT 6, on the other hand, contained cultural material above a zone with evidence of pedogenic perturbation. Beneath approximately $38 \mathrm{~cm}$ of asphalt and construction fill, there was an A-Bt1-Bt2-Bt3$\mathrm{Bk} / \mathrm{C}$ soil profile. From 38 to $51 \mathrm{cmbs}$, brick fragments were encountered, and sediment screened from approximately 38 to $61 \mathrm{cmbs}$ yielded a nine pieces of lithic debitage. While these prehistoric cultural materials were not observed in situ, characteristics of the sediments from which they were recovered suggest a relatively high level of integrity. As previously mentioned, a zone containing evidence of shrinkswell processes was observed beneath artifactbearing sediments, at approximately $113-200$ cmbs. At the bottom of the profile, the $\mathrm{Bk} / \mathrm{C}$ horizon contained occasional carbonate nodules.

The final four backhoe trenches were excavated in Butler Hall's parking lot, to the north of the previously described six backhoe trenches. BHTs 7 and 8 had profiles that contained a buried soil. BHT 7 had a 1A-1Bt-1C-2A-2B/C profile beneath approximately $100 \mathrm{~cm}$ of asphalt and construction fill, and BHT 8 exposed a 1A-1B/ C-2A-2B/C beneath about $90 \mathrm{~cm}$ of asphalt and construction fill. BHT 7 did not contain any cultural material, whereas BHT 9 contained a single piece of lithic debitage, recovered from sediment at $92-124 \mathrm{cmbs}$. The depth of the artifact recovered from BHT 8 places it approximately 
within the upper soil. There were no apparent diagnostic qualities to either the artifact or the soil, and so the age of the deposit is unclear. Characteristics of the soil suggested that it was intact, and therefore, it could potentially contain intact cultural deposits. The buried soils in both BHTs 7 and 8 were very similar, but cultural material was not recovered from or observed in either. It is, however, not clear that the deposits predate archaeologically significant periods.

BHT 9, near the base of a very steep slope, was excavated approximately $50 \mathrm{~m}$ to the north of BHTs 7 and 8. Reaching a depth of 170 cmbs, BHT 9 was relatively shallow, but it did contain an A-AB-Bt-Btk/C soil column beneath approximately $50 \mathrm{~cm}$ of asphalt/cement and construction fill. This trench also contained a single piece of lithic debitage from screened sediment at approximately $92-124 \mathrm{cmbs}$. The sediment from which the artifact came was the designated $\mathrm{BtK} / \mathrm{C}$ horizon, and it also contained soft carbonate nodules. Carbonate nodules suggest that a considerable, though unknown amount of time has passed since the soil was deposited. Other characteristics of this zone/horizon present no signs of significant disturbance, and thus, cultural materials contained therein could potentially be intact.

BHT 10 was an anomalous trench in two respects: it contained sediments that appeared to be the result of different depositional processes, and it also contained the only projectile point recovered during this project. It has been noted that the depositional processes responsible for the sediments encountered in BHTs 1 through 9 are likely a combination of flood deposits and in situ weathering, whereas relatively high amounts of matrix-supported gravel in BHT 10 's four nonfill zones suggest a colluvial origin of sediment. BHT 10 exposed a Fill/Ap-A-B$\mathrm{Bk} / \mathrm{C}$ soil profile beneath approximately $70 \mathrm{~cm}$ of extremely gravelly ( $>50$ percent) fill. Soil development appeared to be relatively free of disturbance, and thus is considered intact. Intact colluvial sediments, however, do not necessarily preserve intact cultural deposits, especially in the case where cultural materials are transported by the same processes as sediment. It is not clear whether or not the projectile point, which was recovered from near the boundary between Zones V and VI ( 108 cmbs), was originally deposited in or transported to this location. In addition to the projectile point, a single piece of lithic debitage was recovered from a comparable depth, but the presence of this artifact does little to help diagnose the integrity of these deposits.

\section{Conclusions and Interpretations of Backhoe Excavations}

Backhoe trenches excavated in Sterry Hall and Falls Hall parking lots (BHTs 1, 2, 4-6) exhibited similar patterns of soil development. However, BHTs 1 and 2 appear to have been excavated on an older alluvial terrace that is now obscured by University modifications. The few artifacts that were recovered from these trenches appear to have come from intact sediments, and therefore, the upper portions of the natural (e.g., nonfill) profiles could potentially contain intact cultural deposits. These interpretations exclude, of course, BHT 3, which contained fill associated with a former gas station location/footprint. Sediments and soils observed in Butler Hall's parking lot were slightly different. BHTs 7 and 8 both contained two buried soils of unknown age. The upper of these buried soils could possibly represent the outer limits of colluvial-alluvial sediment interfingering. At any rate, sediments appeared intact and were deposited in relatively low-energy environments, and are likely to have greater potential to contain intact cultural deposits. BHT 9 contained relatively shallow but intact soils. BHT 10 contained diagnostic 
cultural material in colluvial matrix, and so it is not entirely clear that cultural deposits contained therein are intact. Overall, limited amounts of archaeological material and sediments potentially capable of containing additional remains were encountered throughout the project area. Aside from a couple of areas described above, very few cultural deposits appear to be present in the APE.

\section{Conclusions and Recommendations}

Ten backhoe trenches were excavated at the designated location of the proposed PAC complex at Texas State University-San Marcos. The trenches were placed in the parking lots of Sterry Hall, Falls Hall, and Butler Hall, and all excavations were monitored by archaeologists from CAS. During this work, archaeologists recovered a total of 53 artifacts consisting mostly of historic and modern debris. While some prehistoric material was recorded, the distribution of the material was sparse and did not indicate any intact cultural zones. Included among the prehistoric material was one Nolanlike projectile point from BHT 10; however, it was determined that the matrix in which the point was recovered was deposited by colluvial processes. As a result of this depositional process, together with the two humate dates that bracket the deposit containing the Nolan point, these deposits are either not intact or do not contain in situ cultural materials that have high contextual integrity. Based on these results, the projectile point is considered to be out of context.

Due to the scarcity of intact prehistoric cultural material, this project area is considered to have little research potential and therefore is recommended as ineligible for nomination to the NRHP or for listing as an SAL. However, the encountered prehistoric deposits are similar to those encountered during investigations of the adjacent SAL 41HY161. Therefore, CAS recommends that the site boundaries of 41HY161 be extended to include the PAC project area. An updated TexSite form describing the current investigations along with an updated site boundary will be submitted to the Texas Archeological Research Laboratory (TARL). CAS recommended that the University be granted regulatory clearance in regards to cultural resources and that the University be allowed to proceed with this undertaking with the understanding that spot archaeological monitoring will be conducted during the construction phase of this project.

CAS's recommendations concerning the PAC project were presented to the THC in a letter report on November 1, 2010. The THC concurred with the findings and issued a "no significant sites" determination on November 24, 2010, allowing the project to proceed (Appendix D). 


\section{Chapter Twelve}

\section{Generator Installation at the Freeman Aquatic Biology Building Project}

By Antonio Padilla

On October 18, 2010, CAS archaeologists conducted a small archaeological assessment adjacent to the Freeman Aquatic Biology Building on the University campus (Figures 12-1 and 122). The Office of Facilities Planning Design and Construction plans to install a small generator at this location, with concrete piers extending to a depth of 36 inches $(91.44 \mathrm{~cm})$ below ground surface. The proposed project area is located within site 41HY161, a documented SAL that contains deposits extending from Paleoindian to historic periods. The proposed location is thought to have a high probability for intact cultural deposits. The purpose of the investigations was to explore this possibility and to ensure that significant deposits would not be disturbed during this project. Work was conducted by Project Archaeologist Antonio Padilla, who was assisted by Eric Wettengel.

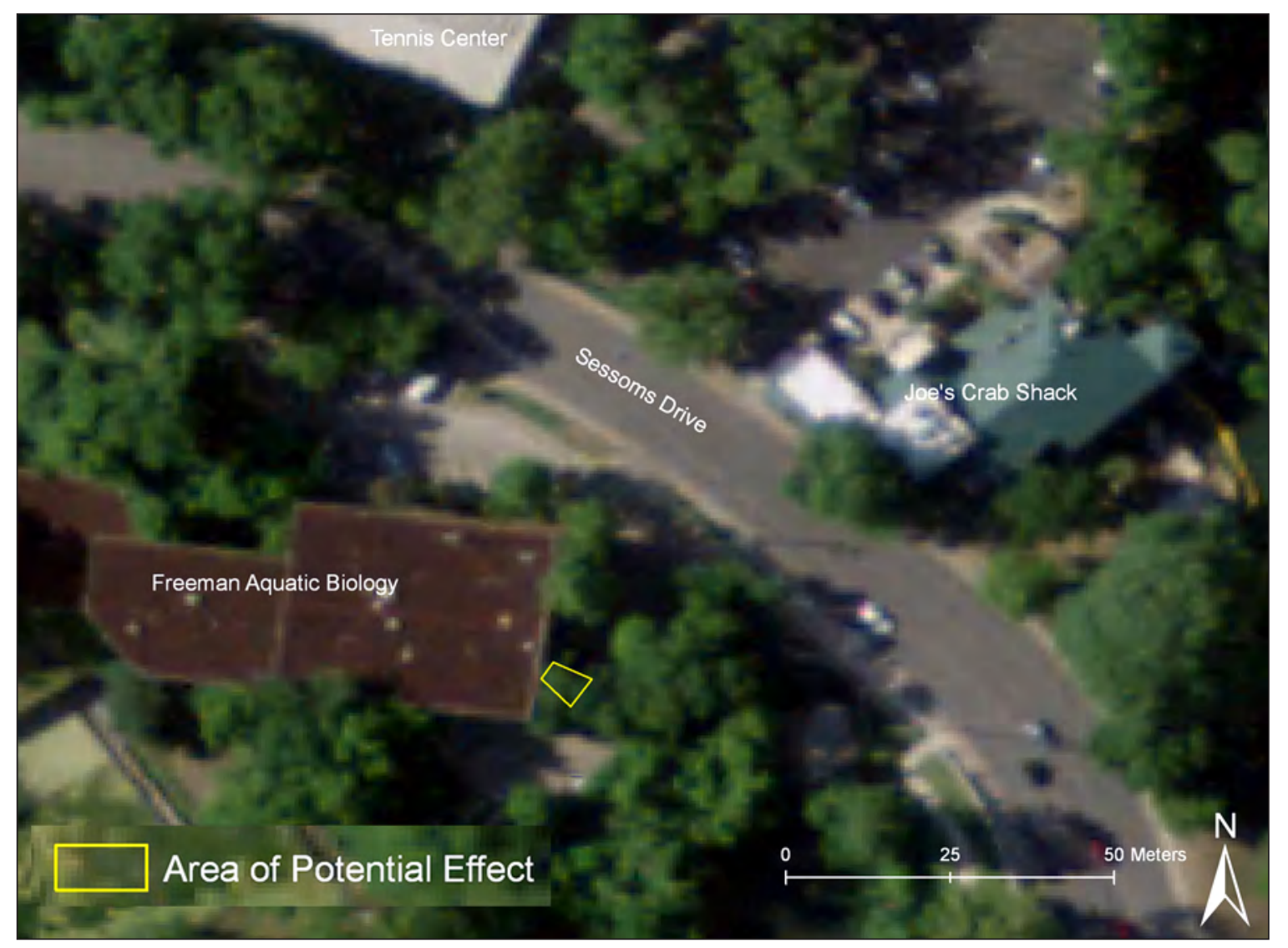

Figure 12-1. Project location. 


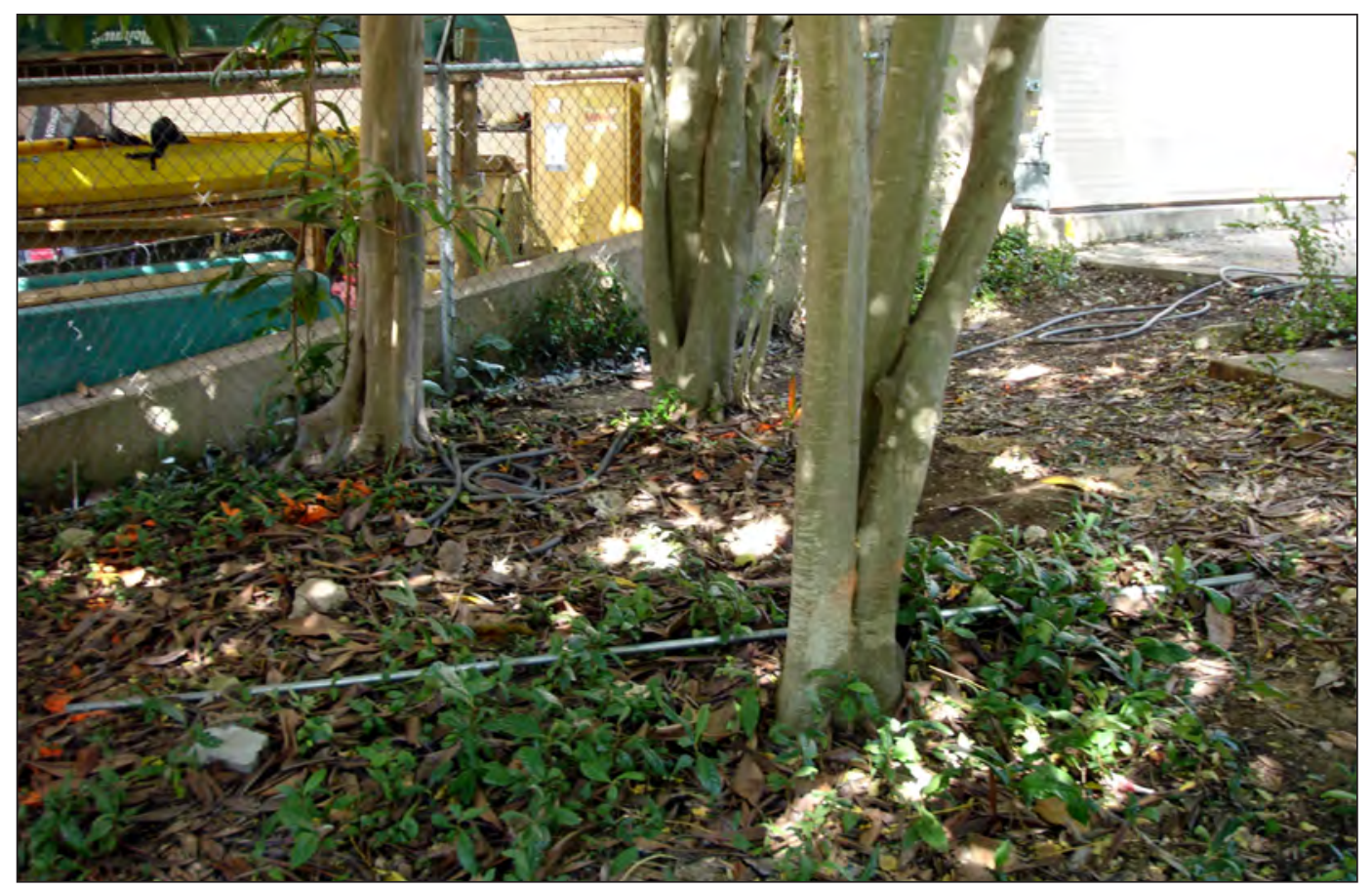

Figure 12-2. Overview of project location.

\section{Methods}

In the Scope of Work for this effort, CAS proposed to excavate three small-scale (30 $\mathrm{cm}$ diameter) test units within the proposed project area. Units were to be excavated in 10$\mathrm{cm}$ arbitrary levels to $100 \mathrm{cmbs}$. This depth corresponds with the deepest proposed impact from the installation of the generator.

Prior to archaeological investigations, the project location was visited to ascertain its present condition and determine whether the work outlined in the original scope of work was possible. It was determined that the project area had likely been impacted by past construction associated with the construction of the Freeman Aquatic Biology building, surrounding parking lots, an irrigation system, and the construction of a concrete pad for a dumpster. Based on these past construction activities, it was determined that the upper sediments within the project area had a high probability of being at least partially disturbed. Therefore it was proposed that a single shovel test, serving as a control unit, would be excavated to $100 \mathrm{cmbs}$ to determine if any intact sediment lay beneath the surface. If any intact soils were encountered, two additional subsurface probes measuring $50 \times 50 \mathrm{~cm}$ would then be excavated in 10-cm arbitrary levels to a depth of $100 \mathrm{cmbs}$. If the control unit failed to yield intact soil deposits, two additional shovel probes were to be expediently excavated to further record disturbances in the area. All excavated soils were to be screened through 1/4-inch mesh, artifacts recovered were to be recorded by provenience, and locations of the probes were to be recorded with a handheld GPS device.

\section{Results}

During the excavation of the control unit, organic sediments were encountered in the upper $30 \mathrm{~cm}$. The soils were mottled with orange-colored clay and had inclusions of rootlets, leaf litter, small gravels, and modern trash (glass, metal, plastic, and paper). The upper sediments were 


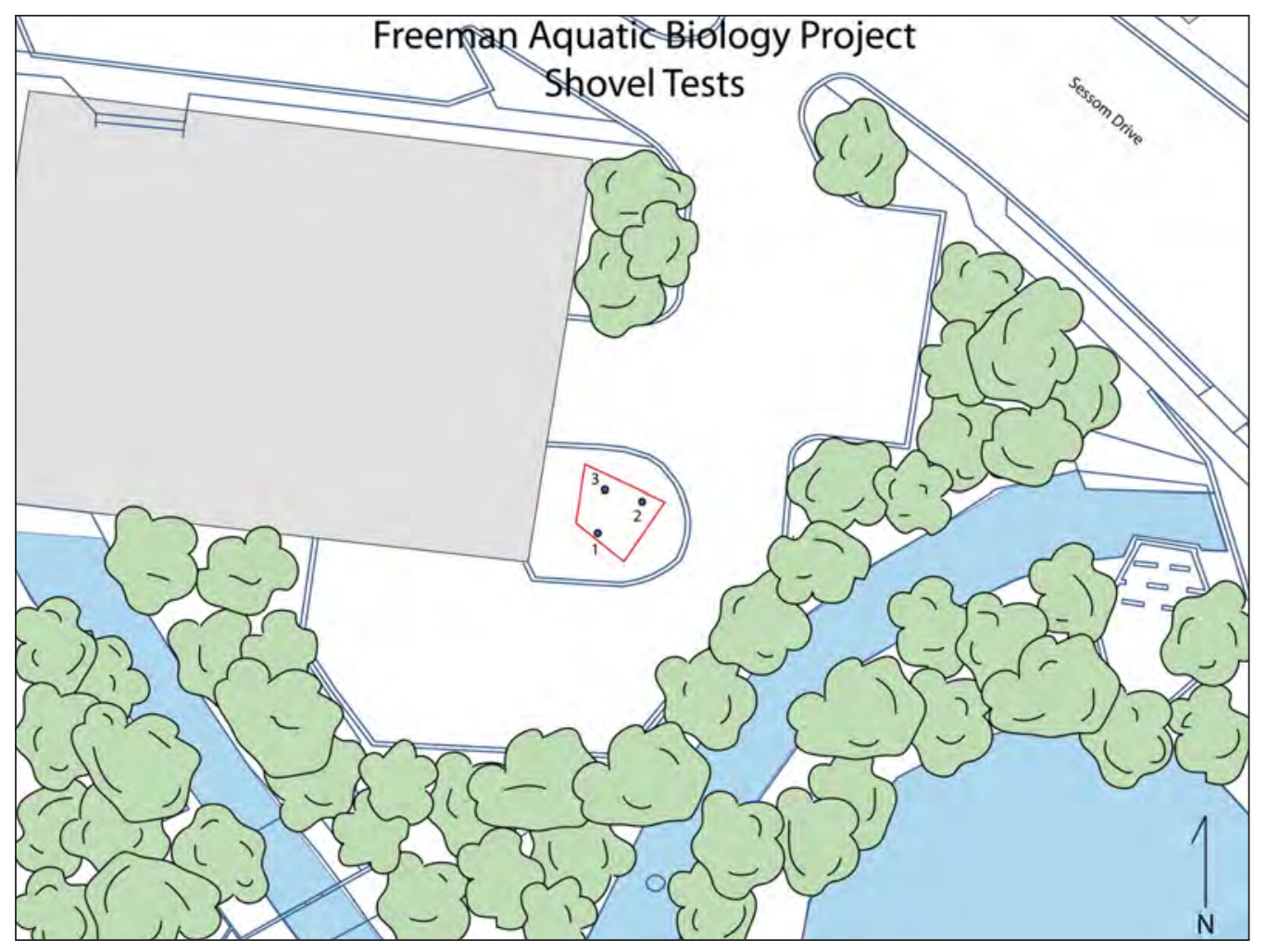

Figure 12-3. Location of shovel tests within project area.

underlain by compact base (construction fill), which was encountered at $30 \mathrm{cmbs}$ and consisted of small to large crushed gravels and marl. At $90 \mathrm{cmbs}$, the base became more compact with larger gravels and extended to beyond $100 \mathrm{cmbs}$. Due to the compactness of the base material, it is presumed that the base material continues well below the proposed depth of impact of the project area. As a result of encountering these disturbed, modern fill layers, the remaining proposed excavations were excavated as shovel tests. Due to the lack of intact buried soil deposits, only the upper sediments of the remaining two shovel tests were excavated and ultimately terminated once the base fill was encountered. The upper matrix of the two additional shovel tests was consistent with that found in the initial shovel test and contained disturbed soils with rootlet inclusions, small gravels, and modern trash. Shovel tests were evenly distributed throughout the project area (Figure 12-3).

\section{Recommendations}

No cultural materials were encountered during the investigations of the Freeman Aquatic Biology Building generator location. Three shovel tests (including a control unit) demonstrate that the project area has been heavily impacted by past construction activities. The entire area is underlain by construction fill encountered at a depth of $30 \mathrm{cmbs}$ and extending well below the proposed depth of impact. Due to these disturbances and the lack of cultural remains, the proposed undertaking will have no potential to encounter or disturb intact, significant cultural deposits. Therefore, CAS recommends that no further work is warranted within the project area and that the University be granted regulatory clearance to proceed with this undertaking without further concern for negative impacts on cultural resources. 


\title{
Chapter Thirteen
}

\section{Additional Archival Investigations}

\author{
By Antonio Padilla and Carole Leezer
}

As an institution of higher learning of the State of Texas, the University is responsible for complying with requirements of the Texas Antiquities Code, which requires the University and other agencies to consider the effect of their undertakings on cultural (historic and prehistoric) resources that are potentially important to local, regional, or state history. For the University's 10-year Campus Master Plan (2006-2015), this means that locations for the development of new buildings may need to be evaluated to determine whether they are significant from a historical perspective, and whether they were associated with people or events that were important in local, regional, or state history. If information indicates that important people or events are associated with a particular locale, additional investigations may be required during the development of that property to offset the possible loss of relevant information about those historically significant issues.

At the request of the University's Asociate Vice President for Finance and Support Services, CAS conducted archival investigations for some property clusters located on campus that are identified as suitable for future potential development. The objective of this work was to develop appropriate levels of historical information for these specific properties that are under consideration for development by the University. In this context, "appropriate" means a level of information that can be used to determine, in advance of a project, whether historically significant persons or events are associated with that particular property and whether additional considerations are likely to be required as developments are prioritized. These archival investigations are intended to be used for planning purposes in conjunction with the University's Master Plan and are limited to historical information pertaining to the period of settlement in San Marcos, dating from the initial founding of the town in 1846 up to the mid-1900s. Most, if not all, of the necessary information was gathered from archival sources held in the University's archives, located at Alkek Library. Additional sources were at the Hays County Courthouse and the archival files of the San Marcos Public Library. Properties subject to archival investigations included: Track Relocation, Alumni Visitor Center, New Housing, Cogeneration Addition, Department of Housing and Residential Life Office Building, Engineering and Science Building, and University Performing Arts Center (Figure 13-1).

Properties were evaluated for eligibility for SAL designation with reference to the criteria presented in Sections 26.7 and 26.8 of Chapter 26, the Rules of Practice and Procedure for the Antiquities Code of Texas. They were also assessed for eligibility for nomination to the NRHP based on criteria presented in 36CFR60. 


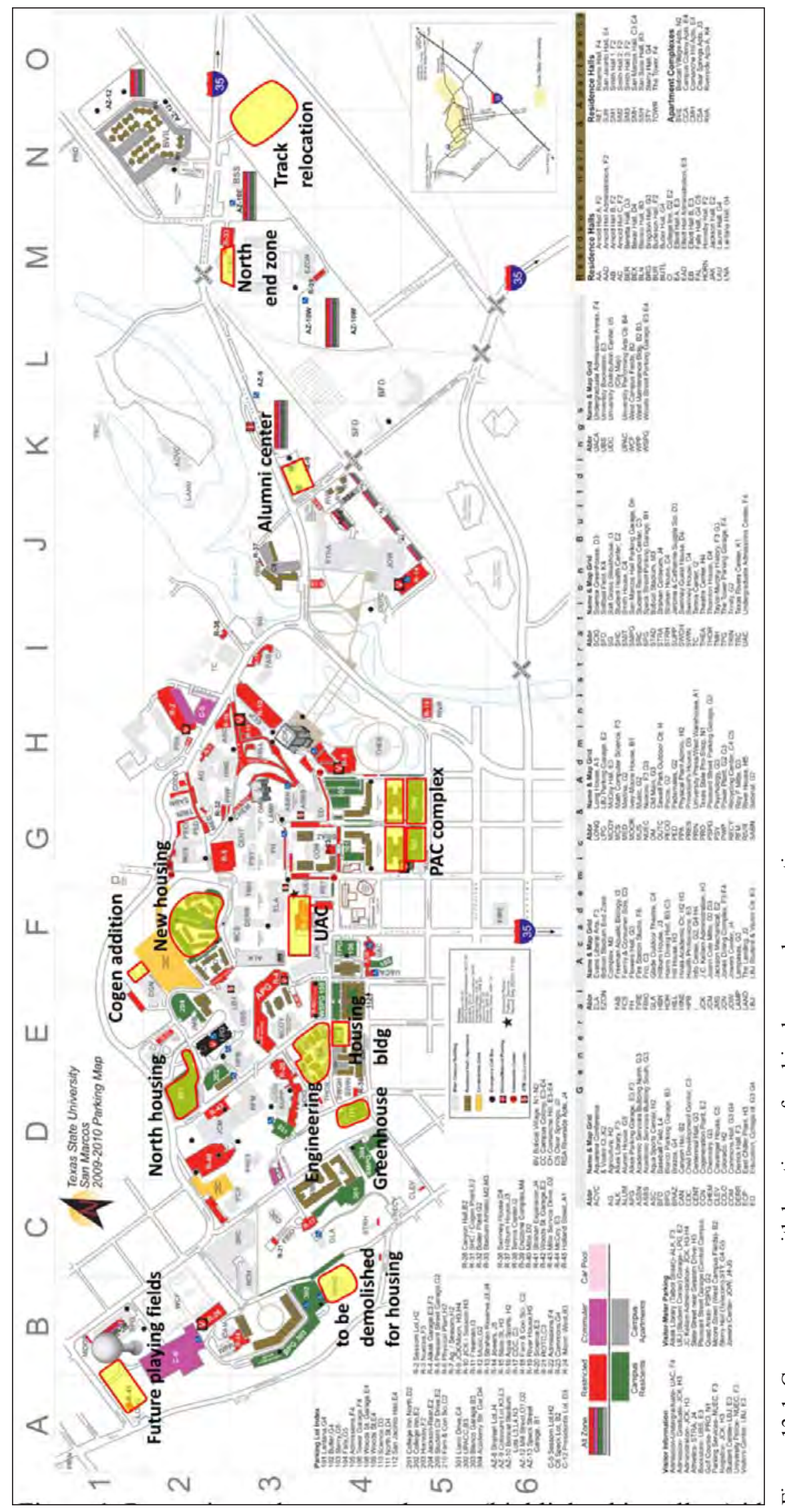

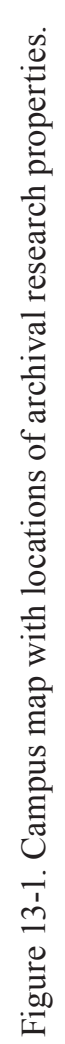




\section{Track Relocation Development Project}

Due to the development of the Bobcat Stadium North Side Complex, the existing track at Bobcat Stadium must be relocated. The University proposes to relocate its current track and field facility to a location adjacent to Bobcat Stadium (see Figure 13-1). The proposed location is directly southeast of the existing Bobcat Stadium parking lot on property that was once the location of the Hidden Village Apartments. These apartments were demolished in 2009 by the University, which is currently in the process of acquiring two additional properties that are situated between the easternmost Bobcat Stadium parking lot and the Hidden Village Apartment site. These two parcels consist of a 0.62-acre parcel that currently belongs to the City of San Marcos Housing Authority and a small, 0.12-acre parcel that belongs to the City of San Marcos.

The proposed project area is located 0.12 miles east of Post Rd., 0.02 miles southwest of Aquarena Spring Dr., 0.04 miles northwest of Thorpe Lane, and 0.05 miles southeast of Warden Lane. A deeds and records search was conducted on parcels located within the project area. During archival investigations no person of historical significance was found to have lived on the parcels. The project area is located on a portion of the J. M. Veramendi League No. 2, which over the years had been divided into numerous smaller lots where urban and housing development has occurred.

The property under consideration for development, however, is located upon a low firstorder alluvial terrace along the southern valley sidewall of the Sink Creek/San Marcos River valley. This area is approximately 2,000 ft east of Sink Creek, and is located in what would have been a desirable location in prehistoric times, affording proximity to rich riverine and floodplain resources while remaining above occasional flood levels. Other than the series of apartment buildings that have been located and demolished here, no other known disturbances have occurred that would potentially have disturbed or removed any remaining alluvial deposits. A review of the Texas Archeological Sites Atlas shows that the area has never been previously surveyed. A multicomponent prehistoric site, 41HY317, is located approximately $400 \mathrm{~m}$ to the north, and two SALs, 41HY160 and 41HY165, are located approximately $550 \mathrm{~m}$ to the east.

Given the location of the project area and the proximity of the Sink Creek waterway, this area would seem to have a reasonably high probability for containing buried cultural resources. However, project design information made available for this undertaking makes it clear that the entire construction site for the new field and track complex will be built up by bringing in and leveling fill. The only excavation to take place below existing grade will be approximately two feet of removal at the west end/upslope portion of the project area. Considering that this zone of disturbance is entirely within the construction zone from the earlier apartment complex, CAS concludes that this undertaking has no chance to encounter or disturb any buried cultural deposits.

\section{Alumni Visitor Center Project}

The University proposes to eventually develop a highly visible Alumni Visitor Center, established at an accessible location that will serve as a gateway for the San Marcos campus. The proposed location of the Alumni Center outlined in the University's Campus Master Plan 2006-2015 is the northwest corner of the Strahan Coliseum parking lot at the intersection of Aquarena Springs Drive and Charles 
Austin Drive (see Figure 13-1). The proposed undertaking is to consist of an L-shaped footprint for a $14,703-\mathrm{ft}^{2}$, two-story building that will front along Aquarena Springs Drive. Although the proposed construction of the Alumni Center will be located on land that is currently owned and used for parking by the University, a deeds and records search was conducted on parcels within the project area.

The project area is located on a portion of the J. M. Veramendi League No. 2, which was granted by the state of Coahuila and Texas to Juan Martín de Veramendi in 1831. Veramendi, however, never lived on the property. Over the course of the years the property had been divided and given to the heirs of J. M. Veramendi. The property remained in the Veramendi family until 1851, when Marco A. Veramendi conveyed the land to William $\mathrm{H}$. Meriwether in 1847. Subsequently, ownership of land changed hands to various families until Shadrach Dixon conveyed the property to the International Great Northern Railroad Company in 1871. The International Great Northern railroad company retained ownership of the property until the company was purchased by the Missouri Pacific Railroad in 1956. The property was then conveyed to the State of Texas for Southwest Texas State University in 1977.

Of the various property owners of the parcel, the son of one family, Samuel Houston Dixon, has historical significance. Deed records show that in 1851 Shadrach Dixon purchased 1,000 acres of land from Clement P. McKennie and an additional 54 acres of land from William H. Meriwether in 1853. Shadrach Dixon resided on the 1,000 acres previously acquired from McKennie at the time of purchasing the additional 54 acres of land (HCDR B/272). These acquired lands served as the Dixon homestead for 20 years until the property was sold in 1871 .
Samuel Houston Dixon was born on a farm in Hays County on August 4, 1855, to Shadrach and Judith Dixon. He was known as an editor, author, and fruit grower. As an adolescent, Samuel attended the Coronal Institute in San Marcos and went on to earn his baccalaureate degree from Baylor University in 1878. Samuel married Jennie Alice Wagner that same year, and they had five children together. Dixon was on staff of the Galveston News and served in several state appointments, which included committee clerk for the state legislature, chief clerk of the Department of Agriculture, and journal clerk for the Twentieth Legislature. In addition to his state appointments, Dixon was editor of the Southern Mercury, the official paper of the Farmers Alliance, Farmer's World. Dixon also held a series of state agricultural offices and served in the state House of Representatives in 1915. As an agricultural journalist, Dixon helped with the development of the citrus and peach industry in Texas. As a writer Dixon, published various topics ranging from agriculture to historical works (King 2010).

While it can be argued that Samuel Houston Dixon is considered to be a person of significance to the history of Texas, no new and important information concerning the life of Mr. Dixon can be gathered from the parcel under question. Therefore, CAS contends the parcel does not possess any historical significance. It does, however, possess the potential to contain deeply buried prehistoric archaeological deposits.

The proposed project area is adjacent to the Track Relocation Property, and it is also situated on a low first-order alluvial terrace along the southern valley sidewall of the Sink Creek/San Marcos River valley. This location is approximately $150 \mathrm{~m}$ south of Sink Creek, in what would have been a desirable location in prehistoric times, affording proximity to 
rich riverine and floodplain resources while remaining above occasional flood levels. A review of the Texas Archeological Sites Atlas shows that the area also has never been previously surveyed. The proposed project area lies directly adjacent to SALs 41HY161 and 41HY165, and possesses a high probability of buried prehistoric archaeological deposits. These deposits may be negatively impacted by the proposed undertaking. CAS, therefore, recommends that intensive archaeological investigations precede any and all proposed development upon this parcel.

\section{New Housing Project}

The proposed location of the New Housing Building is on the property where Smith Hall, Hornsby Hall, and Burleson Hall are currently located (see Figure 13-1). The existing buildings are designated as residence halls and were built during the 1950s and 1960s construction increase under Southwest Texas State University's presidential administration of John G. Flowers. Both Smith and Hornsby Hall were named after influential people affiliated with the growth of the University. Smith Hall was named after Professor C. Spurgeon Smith, who joined the faculty of Southwest Texas State Normal School in 1913, taught biological sciences, and was an assistant coach for the football team. Hornsby Hall was named after Helen Hornsby, who was one of the seventeen original faculty members of Southwest Texas Normal School. Although the University currently owns these properties, a deeds and records search was conducted on these parcels located within the proposed project area to identify possible historic significance of the property.

Based on a deeds and records search, the project area is located in an area once designated as the G. B. Ezell Addition. This addition was surveyed in 1891 and consisted of seven blocks.
The University currently owns the entire area upon which this addition was once located. During CAS's archival investigations, no person of national historical significance was found to have lived on the parcel. However, a person significant to the history of Texas State University was identified as owning and possibly living on property within the G. B. Ezell Addition.

Records show that Mrs. Lou Oglesby Harris conveyed Lot No. 4 in Block No. 2 of the G. B. Ezell Addition to the State of Texas for the use and benefit of the Southwest Texas State Teachers College at San Marcos, in 1938. Mrs. Lou Harris was the widow of Thomas Green Harris, the first president of Southwest Texas State Normal School. Thomas Green Harris purchased the property from Maud Lancaster in 1929. The Harris family owned the property from 1929 to 1938. According to the Texas State Historical Association's Handbook of Texas Online, Mr. Harris was named the first president of Southwest Texas State Normal School (now named Texas State University-San Marcos) in 1903. Thomas Green Harris was born on May 27, 1854, in Sweetwater Tennessee. Mr. Harris received his Bachelor's Degree in 1876 and Master's Degree in 1880 from Carson-Newman College in Jefferson City, Tennessee. In his early career, Mr. Harris taught in Ellijay, Georgia and was superintendent of schools in the Dallas-Fort Worth area. In 1886, Mr. Harris married Lou Oglesby and moved to Dallas. In 1903, they moved to San Marcos, where he was named president of the Southwest Texas State Normal School. After his presidency, Mr. Harris continued working in school systems both as a teacher and superintendent. Thomas Green Harris died in 1934 in San Marcos, Texas.

In addition to the deed research performed by CAS, the Associate Vice President for Finance and Support Services also commissioned a historic architectural building survey by Volz 
\& Associates of 50 campus buildings that were constructed prior to 1965 . The objective of this survey was to help identify potentially important historic resources on the University campus that would require additional consideration, potentially including preservation, as the University developed its 10-year master plan. This survey ranked the oldest and most important buildings that were constructed around the beginning of the University's development as highest priority for preservation. Hornsby Hall was constructed in 1951 in the Spanish Eclectic style. It was historically a women's co-op residence hall. This survey identified Hornsby Hall as possessing a high priority in regards to preservation. This building is scheduled for demolition in order to accommodate the construction of a new housing building.

The Antiquities Code of Texas requires that rehabilitation or demolition of a building owned by a state agency or university that is listed or eligible to be listed on the NRHP must be reviewed by the THC. The Volz and Associates survey, which ranked Hornsby Hall highly in terms of preservation, can be considered an internal planning document at present; its findings may prove highly informative to the University as it proceeds with its 10-year development plan, yet those conclusions carry little weight in terms of regulatory coordination between the University and appropriate state or federal agencies. Accordingly, CAS recommends that the University initiate the consultation process with the THC, the SHPO for Texas, with respect to the planned demolition of Hornsby Hall. The determination of whether a property is eligible for nomination to the NRHP and eligibility for listing as an SAL lies with the THC/SHPO, and the THC should be given the opportunity to comment on that undertaking before it gets underway.

\section{Cogeneration Addition}

The proposed Cogeneration Addition consists of two additions. One will be attached to the northwest corner of the existing Cogeneration Building, a power and chiller facility, and a second will include a free-standing structure added to the west of the existing building (see Figure 13-1). The existing Cogeneration Building is located south of Sessom Drive, just northwest of Buckner Street. Construction of this building took place between 1987 and 1989. Although the University currently owns these properties, a deeds and records search was conducted on parcels located within the proposed project area to identify possible historic significance of the property.

Based on a deeds and records search, the project area is located in Lots $120,121,123$, and 125 of the Fourth Division of the Park Addition to the City of San Marcos. According to the mapped location of the Park Addition in comparison to current maps, the University currently owns the property upon which the entire Park Addition (1 through 4) was once located. During archival investigations, no persons, events, or buildings of historical significance are associated with this parcel. Additionally, the criterion listed in Section 26.7 and Section 26.8 of Chapter 26 Rules and Procedures for administering the Antiquities Code of Texas with respect to SALs appears not to have been met.

\section{Department of Housing and Residential Life Office Building Project}

The current reassignment of auxiliary operations within the Department of Housing and Residential Life to multiple locations on and off campus necessitates the timely construction of a centrally located facility composed of general administrative offices, supplies warehouse, 
maintenance shop, and parking. As a result, the University proposes that a new Housing and Residential Life Office Building be constructed at the northeast corner of the intersection of Woods and Comanche, in a parking lot currently designated for residents of the Comanche Hill campus apartments (see Figure 13-1). A deeds and records search was conducted on parcels located within the proposed project area to identify persons or events of possible historic significance (Table 13-1).

Based on a deeds and records search, the project area consists of Block 2 of the Mountain City Addition to the town of San Marcos, composed of 6 lots. The original Mountain City Addition consisted of 6 blocks and was designated as a subdivision in 1883. According to the mapped location of the subdivision in comparison to current maps, the University has owned the entire Mountain City Addition since 1993.

During archival investigations, no persons, events, or buildings of historical significance are associated with this parcel. Additionally, the criterion listed in Section 26.7 and Section 26.8 of Chapter 26 Rules and Procedures for administering the Antiquities Code of Texas with respect to SALs appears not to have been met.

\section{Engineering and Science Building Project}

Due to expanding enrollment in the Engineering, Material Science, and Biology programs, the University desires to add a major new facility in order to accommodate these rapidly growing programs. This new building will consist of research laboratories, shared interdisciplinary labs, classrooms, facility offices, seminar, and conferencing facilities. The proposed new Engineering and Science Building is to be located on the southwest corner of the intersection of Comanche and Vista, directly northeast of the Thorton House, where the Comanche Hill and Campus Colony campus apartments are currently located (see Figure 131). A deeds and records search was conducted on the parcels composing the proposed project area to identify issues of possible historic importance associated with the property.

Archival investigations revealed that the project area was once Block 4 of the Mountain City Addition to the town of San Marcos, and was composed of 9 lots. The original Mountain City Addition contained six blocks and was designated a subdivision in 1883. According to the mapped location of the subdivision in comparison to current maps, the University currently owns the entire Mountain City Addition.

During archival investigations of the proposed Engineering and Science Building, no persons, events, or buildings of historical significance are associated with this parcel. Additionally, the criterion listed in Section 26.7 and Section 26.8 of Chapter 26 Rules and Procedures for administering the Antiquities Code of Texas with respect to SALs appears not to have been met.

Table 13-1. Past Owners of Parcels or Portion of Parcels to be Developed.

\begin{tabular}{ccc}
\hline Year & Owner & Parcel and/or Portion of \\
\hline 1931 & Basil L. Dailey and L. J. Dailey, Jr. & Portion of Farm Lot 20; Mountain City Addition \\
1986 & Thomas A. Dyke & Portions of the Mountain City Addition \\
1993 & Dyke Family Investments & Portions of the Mountain City Addition \\
\hline
\end{tabular}




\section{University Performing Arts Center}

The University proposes the demolition of the University Performing Arts Center, located on Moore Street south of Blanco Hall, for the purpose of creating space for future student housing developments (see Figure 13-1). A new Performing Arts Center (PAC) Complex is slated for development in the current locations of Sterry and Falls Hall on the southeastern side of the main campus. The PAC building and the property upon which it stands was once part of the San Marcos Baptist Academy.

The San Marcos Baptist Academy is one of the oldest boarding schools in Texas. It was established in 1907 by Texas Baptist with the support of the City of San Marcos. The citizens of San Marcos raised \$13,000 and donated 57 acres (Toma 2009). The Academy opened its doors on September 24, 1908, with 200 students under the direction of its first president James Milton Carroll.

The San Marcos Baptist Academy buildings and property were purchased by Southwest Texas State University on June 19, 1979. A total of $\$ 11.25$ million was paid for the 18 buildings and 78.5 acres of land belonging to the Academy. A gradual transfer occurred over the preceding three years, allowing the Academy to continue to operate while constructing a new campus. The Academy moved to a 200 -acre property located a few miles northwest of the San Marcos city center. Ground was broken on this new location in November 1979, and the first classes were held here in January 1982 (Toma 2009).

Several of the Academy's buildings continued to be used by the University. The Academy's president's home is currently the University's president's home. The Academy's Robinson Christian Center is now the University Performing Arts Center. This 390-seat theater with 55-Ranck pipe organ was built by the San Marcos Baptist Academy in 1973 through a 1971 $\$ 380,000$ donation by Mrs. J. H. Robinson of Edna, Texas.

The building is considered to be of modern construction, and as such lacks historical significance that would meet the criteria for historic structures presented in Section 26.7 of Chapter 26 Rules and Procedures for administering the Antiquities Code of Texas. Historic significance of the property upon which the PAC building stands is associated with the original establishment and development of the San Marcos Baptist Academy in 1907, making it one of the oldest boarding schools in Texas. The history of the San Marcos Baptist Academy has been well documented (Shand 1990; Smith 1954), and therefore, further documentation of this institution is not warranted. 


\title{
Chapter Fourteen
}

\section{Conclusions And Recommendations}

\author{
By Carole A. Leezer
}

CAS conducted several cultural resource management projects on behalf of Texas State University-San Marcos during 2010. These investigations were conducted in accordance with a MOA established between the THC and the University. This MOA authorized CAS to conduct archaeological investigations consisting of monitoring, surface reconnaissance, shovel test investigations, and intensive cultural resource surveys of University-owned lands. CAS conducted these evaluations in 2010 under Texas Antiquities Permit No. 5509. Investigations were conducted to determine if proposed undertakings would have the potential to negatively impact cultural resources, and if so, to recommend to the University courses of action that may avoid or offset impacts. CAS conducted nine cultural resource investigations including the following projects: Aquarena Center Waterline, Center for Research Commercialization, Blanco Hall, Freeman Ranch, Fish Ponds, President's House Irrigation, Undergraduate Academic Center, Performing Arts Center Complex, and the Freeman Aquatic Biology Building Generator. In addition, archival research outside of the scope of the MOA was conducted on the following proposed project locations: Alumni Visitor Center, Cogeneration Addition, Engineering and Science Building, Housing and Residential Life Office Building, New Housing, Track Relocation, and the University Performing Arts Center. Archival research was conducted on these properties to determine, in advance of a project, whether historically significant buildings, person(s), or events are associated with that particular property, and whether additional considerations are required as developments concerning these properties progress.

\section{Archaeological Investigations Recommendations}

\section{Aquarena Center Waterline}

Archaeologists from CAS were called to observe the repair a broken subsurface waterline on the grounds of the Aquarena Center. This area is within the boundaries of SAL 41HY160. As a high potential for encountering cultural deposits in this area exists, archaeological monitoring of the waterline repairs were deemed necessary.

No cultural materials were observed during the monitoring of repairs, and it was recommended that no additional archaeological investigations were warranted. CAS would like to emphasize, however, that this area contains a high potential for intact, subsurface cultural deposits, and that all future ground-disturbing work in this area should be closely coordinated with CAS.

\section{Center for Research Commercialization}

Investigations of this project area consisted of archival research, archaeological monitoring of geotechnical coring, surface reconnaissance, and intensive archaeological survey. During surface reconnaissance, two areas of cultural 
deposits were observed. These areas were further examined during intensive archaeological survey of the project area. As a result, historic archaeological site 41HY477 was identified and recorded.

Due to the disturbed nature of the site and low integrity of deposits, this site was not considered to possess any research potential. CAS recommended the site is not eligible for nomination to the NRHP or designation as an SAL. CAS recommended that the University be granted regulatory clearance to proceed with this undertaking without further concern for negative impacts on cultural resources. This information was presented to THC/SHPO in an interim letter report on August 18, 2010. The THC/SHPO concurred with the above described findings and recommendations on September 13, 2010. No further actions are warranted.

\section{Blanco Hall}

CAS archaeologists were called to monitor the repair to a subsurface fractured condensation line located in front of Blanco Hall. The project area lies approximately $300 \mathrm{~m}$ to the west of historic archaeological site 41HY318, and thus a high probability exists for encountering subsurface historic cultural deposits.

No significant historic or prehistoric cultural materials were noted within the excavated area. CAS recommends that future ground-disturbing activities in this area be closely coordinated, as this area contains a high probability for subsurface historic cultural deposits.

\section{Freeman Ranch}

The excavation of four trenches measuring $3 \times 1.4 \mathrm{~m}$ and $47 \mathrm{~cm}$ deep was monitored by archaeologists from CAS. Previous investigations at Freeman Ranch recorded a prehistoric surface scatter of lithics, and there is a reasonable probability that additional cultural resources are also present. In additional to the geological setting, easily accessible upland chert deposits and intermittent streams likely made this property very attractive to prehistoric peoples.

While no subsurface cultural remains were noted in any of the trenches, cultural remains were noted on the surface near two of the four excavated trenches. Based on these observations, previous investigation on the ranch, and the occasional recovery of temporally diagnostic point types, CAS concludes that the full inventory of cultural resources at Freeman Ranch remains unknown. Future developments here should be coordinated prior to those undertakings. Ideally, a full archaeological assessment of the property should be conducted. This study could serve as a planning tool for how the University uses and manages the ranch in ways that avoid impacting archaeological deposits.

\section{Fish Ponds}

CAS archaeologists were called to monitor two trenches excavated to identify and repair a waterline break in the area of the old fish hatchery ponds. This project area is located within the boundaries of SAL 41HY161, and a high probability exists for encountering subsurface cultural materials.

While subsurface cultural materials were encountered, they were in mixed context with low integrity. As such, the encountered deposits did not possess research potential and CAS recommends that no further archaeological investigations were warranted. However, because the project area is located within the boundaries of SAL 41HY161, the University should continue to coordinate any future work in the area of the old fish hatchery ponds with CAS. 


\section{President's House}

Archaeological monitoring of trench excavations in association with the installation of a new sprinkler system for the President's House was conducted by CAS archaeologists. Trenches were excavated on the west side of the President's house approximately $30 \mathrm{~m}$ to the west of historic archaeological site 41HY318. Based on the proximity of this site to the project area, a high probability for encountering subsurface historic cultural deposits existed.

A mid-twentieth-century bottle fragment was collected from the surface near one of the trenches, but no prehistoric or historic subsurface cultural deposits were encountered. CAS determined that no research potential exists for the excavated area and that no additional investigations are warranted. Future work in this area, however, needs to be closely coordinated with CAS due to the presence of archaeological site $41 \mathrm{HY} 318$.

\section{Undergraduate Advising Center}

CAS archaeologists conducted archival research and archaeological monitoring associated with the planned construction of the Undergraduate Advising Center. Archival research indicated that San Marcos's first Catholic Church, Our Lady of Guadalupe, was established on property adjacent to the southern portion of the project area in 1883. In 1915, following the burning and demolition of the previous church building, a new Catholic Church, St. John's the Evangelist, was erected on parcels making up the southern portion of the project area. This church, too, eventually burned and was demolished in 1970. The church then relocated to Hopkins Street and the previous location was purchased by Southwest Texas State University (now Texas State University). Based on this information, archaeological monitoring was conducted in the event that subsurface deposits associated with the previous occupation of the parcel were encountered.

During archaeological monitoring, the considerably disturbed remains of St. John's Catholic Church were encountered. No significant and intact cultural deposits were encountered, leading CAS to conclude that the project area is not eligible for nomination to the NRHP or for designation as an SAL. CAS recommended that construction of the Undergraduate Academic Center proceeded without delay.

\section{Performing Arts Center Complex}

Archaeologists from CAS conducted archival research and archaeological investigations associated with the planned construction of the Performing Arts Center Complex. As the proposed construction of the Performing Arts Center includes the demolition of Falls Hall and modifications to the surrounding landscape, archival investigations included a review of this undertaking. The building is not considered to be historically significant, and the review of property deeds within the project area identified no persons of historical significance that are or have been associated with the project area. An NRHP-eligible property, the Hutchinson House, lies immediately adjacent to the proposed project area. President-to-be Lyndon B. Johnson took his meals here and may have also boarded here while a student at Southwest Texas Teachers College. This property will not be affected by the proposed construction project. The majority of the parcels upon which the proposed project is located were obtained by the University as part of the Urban Renewal program of 1964.

As the project property is located on an alluvial terrace of the San Marcos River and is also adjacent to SAL 41HY161, archaeological 
investigations of the property were warranted. These investigations consisted of the excavation of 10 backhoe trenches across the project area. Trenches measured $3 \mathrm{~m}$ in length, $1 \mathrm{~m}$ in width, and varied in depth from 1.5 to $3 \mathrm{~m}$.

While intact subsurface cultural materials were encountered, these were exceedingly low in density, consisting only of one or two flakes in each trench. The very low density of recovered materials led CAS to conclude that the area possessed little research potential. CAS recommended that no additional archaeological investigations need to be conducted. However, CAS does recommend that the site boundaries for the SAL be extended to include the cultural remains encountered here. As the potential for unidentified subsurface cultural materials exists within the project area, CAS will conduct spot archaeological monitoring of all demolition/ construction activities. The above-outlined recommendations concerning the Performing Arts Complex Project were presented to the THC in an interim letter report on November 1, 2010. The THC concurred with the findings allowing the project to proceed.

\section{Freeman Aquatic Generator}

CAS archaeologists conducted a small-scale archaeological investigation of the location of proposed generator to be installed adjacent to the Freemen Aquatic Biology Building. Investigations were warranted, as the construction area is located within SAL 41HY161. Investigations consisted of the excavation of three shovel test to a depth between 30 and $100 \mathrm{~cm}$.

Excavations revealed that the project area is underlain by construction fill encountered at $30 \mathrm{cmbs}$ and extending well below the proposed depth of impact. As there is no potential for construction to encounter intact cultural remains, CAS recommends that no additional archaeological investigations are warranted and that the proposed construct may proceed.

\section{Additional Archival Research Recommendations}

CAS conducted additional archival investigations apart from the archaeological investigations conducted under the MOA and Texas Antiquities Permit No. 5509 that led to the development of information to be used to determine whether historically significant buildings, persons, or events are associated with properties under consideration for development in with the University's Master Plan. Property locations include those associated with the following developmental projects: Track Relocation, Alumni Visitor Center, New Housing, Cogeneration Addition, Department of Housing and Residential Life Office Building, Engineering and Science Building, and University Performing Arts Center. The evaluations of properties were conducted with criteria for SAL designation in mind. These criteria are presented in Sections 26.7 and 26.8 of Chapter 26, the Rules of Practice and Procedure for the Antiquities Code of Texas. Properties were also assessed for eligibility for nomination to the NRHP based on criteria presented in 36CFR60. Importantly, all information developed through this activity is to be used strictly for planning purposes; no final recommendations are offered with respect to eligibility of any property that will or may be affected.

All properties investigated appeared not to meet the nonarchaeological criteria established for recommendation for SAL designation and for nomination to the NHRP, with the exception of the New Housing Project location. The proposed location of the New Housing Building is on property where Smith Hall, Hornsby Hall, and Burleson Hall are currently located. 
Current proposed plans call for the demolition of Hornsby Hall. A historic building survey by Volz \& Associates of 50 campus building constructed prior to 1965 identified Hornsby Hall as possessing a high priority with respect to preservation. While this report does not clearly state that this is a historically significant building, their survey results do bring this possibility to question. As a result, CAS recommends that the University initiate the consultation process with the THC, the SHPO for Texas, in regards to its planned demolition. The determination of whether a property is eligible for nomination to the NRHP and eligibility for designation as an SAL ultimately lies with the THC/SHPO. Such coordination should take place far in advance of any planned demolition/construction.

During archival investigations, it was also determined that two of the properties under consideration for future development possess at least a minimal possibility for containing buried prehistoric cultural deposits. These parcels include the Track Relocation and the Alumni Visitor Center developments, both of which are to be located on an alluvial terrace of the Sink Creek/San Marcos River valley, adjacent to previously recorded archaeological sites and SALs. Construction design for the Track and Field Relocation, however, indicate that very little actual excavation is to occur here, and the sediments that will be removed lie almost entirely in a zone of disturbance from previous apartment constructions in this location. As a result, CAS recommends that only the Alumni Visitor Center project be subjected to intensive archaeological investigations prior to any development. This assessment should be coordinated with the THC, and should comply with all requirements set forth in state and/or federal law, as appropriate, with respect to cultural resources. 


\section{References Cited}

Aery, D. A.

2007 Organization of Lithic Technology in Archaic Texas: An Example from 41HY160 in San Marcos, Texas. Unpublished Master's thesis, Department of Anthropology, Texas State University-San Marcos.

Arnn, John W., III

2005 Chronology, Technology, and Subsistence: Is That All There Is? Council of Texas Archeologists Newsletter 29(2):17-28.

2007 Transformation and Persistence of Indigenous Cultural Identity during the Early Colonial and Late Prehistoric Periods in Texas. Unpublished PhD dissertation, University of Kentucky, Lexington. University Microfilms, Ann Arbor.

Barrera, Jimmy

2002 San Marcos City Park Archaeological Survey, Hays County, Texas. Technical Report No. 4. Center for Archaeological Studies, Southwest Texas State University, San Marcos.

Batte, C. C.

1984 Soil Survey of Comal and Hays Counties, Texas. United States Department of Agriculture, Soil Conservation Service, in cooperation with the Texas Agricultural Experiment Station.

Black, Stephen L.

1989 Central Texas Plateau Prairie. In From the Gulf Coast to the Rio Grande: Human Adaptation in the Central, South, and Lower Pecos Texas, edited by Thomas R. Hester, Stephen L. Black, D. Gentry Steele, Ben W. Olive, Anne A. Fox, Karl J. Reinhard, and Leland C. Bement, pp. 17-38. Research Series No. 33. Arkansas Archeological Survey, Fayetteville.

1995 Archeological and Ethnohistorical Background. In Archeological Investigations at the Loma Sandia Site (41LK28): A Prehistoric Campsite in Live Oak County, Texas, Vol. 1, by Anna Jean Taylor and Cheryl Lynn Highley, pp. 31-45. Studies in Archeology No. 20. Texas Archeological Research Laboratory, The University of Texas at Austin.

Black, Stephen L., and Al J. McGraw

1985 The Panther Springs Creek Site: Cultural Change and Continuity in the Upper Salado Creek Drainage, South-Central Texas. Archaeological Survey Report No. 100. Center for Archaeological Research, The University of Texas at San Antonio.

Blair, W. Frank

1950 The Biotic Provinces of Texas. Texas Journal of Science 2(1):93-117. 
Bolton, Herbert E.

1970 [1915] Texas in the Middle Eighteenth Century: Studies in Spanish Colonial History and Administration, Vol. 3. University of California Publications in History. University of California, Berkeley.

Bousman, C. Britt, Barry W. Baker, and Anne C. Kerr

2004 Paleoindian Archeology in Texas. In The Prehistory of Texas, edited by Timothy K. Perttula, pp. 15-97. Texas A\&M Press, College Station.

Bousman, C. B., M. B. Collins, P. Goldberg, T. Stafford, J. Guy, B. W. Baker, D. G. Steele, M. Kay, G. Fredlund, P. Dering, S. Dial, V. Holliday, D. Wilson, P. Takac, R. Balinsky, M. Masson, and J. F. Powell

2002 The Paleoindian-Archaic Transition: New Evidence from Texas. Antiquity 76:980-990.

Bousman, C. Britt, and David L. Nickels, assemblers

2003 Archaeological Testing of the Burleson Homestead at 41HY37, Hays County, Texas. Archaeological Studies Report No. 4. Center for Archaeological Studies, Texas State University-San Marcos.

Brune, Gunner

2005 Springs of Texas, Vol 1. Texas A\&M University Press, College Station.

Campbell, T. N., and T. J. Campbell

1985 Indian Groups Associated with Spanish Missions of the San Antonio Missions National Historical Park. Special Report No. 16. Center for Archaeological Research, The University of Texas at San Antonio.

Collins, Michael B.

1995 Forty Years of Archaeology in Texas. Bulletin of the Texas Archeological Society 66:361400.

2004 Archeology in Central Texas. In The Prehistory of Texas, edited by Timothy K. Perttula, pp. 101-126. Texas A\&M University Press, College Station.

Collins, Michael B., and Kenneth M. Brown

2000 The Gault Gisement: Some Preliminary Observations. Current Archeology in Texas 2(1):163166.

Crumley, Carole L. (editor)

1994 Historical Ecology: Cultural Knowledge and Changing Landscapes. School of American Research Press, Santa Fe.

de la Teja, Jesús F.

1995 San Antonio de Bexár: A Community on New Spain's Northern Frontier. University of New Mexico Press, Albuquerque. 
Dillehay, Thomas D.

1974 Late Quaternary Bison Population Changes on the Southern Plains. Plains Anthropologist 19(64):180-196.

Dobie, Dudley R.

1932 The History of Hays County, Texas. Unpublished Master's thesis, The University of Texas at Austin.

Dunn, William E.

1911 Apache Relations in Texas, 1718-1750. Southwestern Historical Quarterly 14:198-274.

Ellis, Linda Wootan, G. Lain Ellis, and Charles D. Frederick

1995 Implications of Environmental Diversity in the Central Texas Archeological Region. Bulletin of the Texas Archeological Society 66:401-426.

Fisher, Lewis F.

1998 The Spanish Missions of San Antonio. Maverick Publishing Company, San Antonio.

Ford, O. A., and A. S. Lyle

1998 Archaeological Investigation of a Spring Lake Lot for Joe's Crab Shack Parking. Archaeological Survey Report No. 277. Center for Archaeological Research, The University of Texas at San Antonio.

Foster, William C.

1995 Spanish Expeditions into Texas 1689-1768. University of Texas Press, Austin.

Garber, J. F., S. Bergman, B. Dickinson, R. Hays, III, J. Simpson, and J. Stefanoff

1983 Excavations at Aquarena Springs, San Marcos, Texas. La Tierra 10:2:28-38.

Garber, J. F., and D. M. Glassman

1992 Excavation of Human Remains from the Fish Pond Site, 41HY161, in San Marcos, Hays County, Texas. Texas Antiquities Permit Number 338. Department of Sociology and Anthropology, Southwest Texas State University, San Marcos.

Garber, J. F., and M. D. Orloff

1984 Excavations at 41HY37: An Archaic Site on the Balcones Escarpment in San Marcos, Texas. La Tierra 11:3:31-37.

Giesecke, J.

1998 Faunal Analysis from 41HY165: An Independent Study. Manuscript on file, Anthropology Department, Southwest Texas State University, San Marcos. 
Goode, Glenn T.

1989 Archaeological Testing and Recommendations for the Kennedy Bluffs Site, 41BP19, in Bastrop County, Texas, Appendix II. In Excavations at 41BP19, the Kennedy Bluffs Site, Bastrop County, Texas, edited by Leland C. Bement, pp. 155-180. Contract reports in Archaeology, Report 5. Texas State Department of Highways and Public Transportation, Highway Design Division, Austin.

Gould, F. W.

1962 Texas Plants-A Checklist and Ecological Summary. The Agricultural and Mechanical College of Texas, Texas Agricultural Experiment Station, College Station.

Habig, Marion A.

1977 The Alamo Mission: San Antonio de Valero, 1718-1793. Franciscan Herald Press, Chicago.

Hall, Grant D.

1981 Allens Creek: A Study in the Cultural Prehistory of the Brazos River Valley, Texas. Texas Archaeological Survey Research Report No. 61. The University of Texas at Austin.

Hester, Thomas R.

1983 Late Paleo-Indian Occupations at Baker Cave, Southwestern Texas. Bulletin of the Texas Archeological Society 53:101-119.

1995 The Prehistory of South Texas. Bulletin of the Texas Archeological Society 66:427-459.

2004 The Prehistory of South Texas. In The Prehistory of Texas, edited by Timothy Perttula, pp. 127-151. Texas A\&M University Press, College Station.

Holliday, Vance T.

1997 Paleoindian Geoarchaeology of the Southern High Plains. University of Texas Press, Austin.

Houk, Brett, and Jon Lohse

1993 Archeological Investigations at the Mingo Site, Bandera County, Texas. Bulletin of the Texas Archeological Society 61:193-247.

Huebner, Jeffery A.

1991 Late Prehistoric Bison Populations in Central and Southern Texas. Plains Anthropologist 36(137):343-358.

Johnson, LeRoy, Jr.

1994 The Life and Times of Toyah-Culture Folk; the Buckhollow Encampment Site 41KM16, Kimble County, Texas. Office of State Archeologist Report 38. Texas Department of Transportation and the Texas Historical Commission, Austin.

Johnson, LeRoy, Jr., and T. N. Campbell

1992 Sanan: Traces of a Previously Unknown Aboriginal Language in Colonial Coahuila and Texas. Plains Anthropologist 37(140):185-212. 
Johnson, LeRoy, Jr., and Glenn T. Goode

1994 A New Try at Dating and Characterizing Holocene Climates, as well as Archeological Periods, on the Eastern Edwards Plateau. Bulletin of the Texas Archeological Society 65:1-51.

Jones, Richard S.

2002 Archaeological Trench Monitoring Near Prehistoric Site 41HY161, Hays County, Texas. Technical Report No. 3. Center for Archaeological Studies, Texas State University-San Marcos.

2003 Annual Report to Southwest Texas State University for Texas Antiquities Permit No. 2624, Hays County, Texas. Technical Report No. 9. Center for Archaeological Studies, Texas State University-San Marcos.

Kelley, J. Charles

1947 The Lehmann Rock Shelter: A Stratified Site of the Toyah, Uvalde, and Round Rock Foci. Bulletin of the Texas Archeological and Paleontological Society 18:115-128.

King, Brian

2007 Archeological Survey of the Proposed City of San Marcos Pedestrian Bridge in Hays County, Texas. Archeology Series No. 183. Hicks \& Company, Austin, Texas.

King, Keith L.

2010 Texas State Historical Association, Handbook of Texas Online, s.v. "Dixon, Samuel Houston," http://www.tshaonline.org/handbook/online/articles/fdi31 (accessed December 20, 2010).

Leezer, Carole, Julian A. Sitters, and Sarah Scogin

2010 Archaeological Assessment and Monitoring for Construction of a New Boiler Station at Jowers Center and Sewell Park, Texas State University-San Marcos, Hays County, Texas. Technical Report No. 38. Center for Archaeological Studies, Texas State University-San Marcos.

Lemke, Ashley, and Cinda Timperley

2008 Preliminary Analysis of Turtle Material from the Gault Site, Texas. Current Research in the Pleistocene 25:115-117.

Lindsey, Bill

2010 Historic Glass Bottle Identification and Information Website. Electronic document, http:// www.sha.org/bottle/index.htm (accessed 13 April 2010).

Lohse, Jon C.

1999 Lithics from the San Antonio de Valero Mission: Analysis of Materials for the 1979 Excavations of the Alamo. Bulletin of the Texas Archeological Society 70:265-279. 
Lukowski, Paul D., with contributions by Robert F. Scott IV and Richard F. Shoup

1988 Archaeological Investigations at 41BX1, Bexar County, Texas. Archaeological Survey Report No. 135. Center for Archaeological Research, The University of Texas at San Antonio.

Lyle, A., C. Horrell, S. A. Tomka, and D. A. Cargill

2000 Archaeological Testing at the Headwaters of the San Marcos River: Southwest Texas State University Raw Water Supply Project. Archaeological Survey Report No. 293. Center for Archaeological Research, The University of Texas at San Antonio.

McGraw, Al J., John W. Clarke, Jr., and Elizabeth A. Robbins (editors)

1991 A Texas Legacy: The Old San Antonio Road and the Caminos Reales, A Tricentennial History, 1691-1991. Texas State Department of Highways and Public Transportation, Austin.

Newcomb, William W., Jr.

1961 The Indians of Texas From Prehistoric to Modern Times. University of Texas Press, Austin.

1993 Historic Indians of Central Texas. Bulletin of the Texas Archeological Society 64:1-63.

Nickels, David L., and C. Britt Bousman (assemblers)

2010 Texas River Center Archaeology, Test Excavations at 41HY160, Hays County, Texas. Archaeological Studies Report No. 13. Center for Archaeological Studies, Texas State University-San Marcos.

Niehaus, Father Jonathan

2008 Catholics at Texas State: From the Newman Club to St. Jude Chapel (1914-2008). H.L. Grant Catholic Student Center and St. Jude Chapel, San Marcos.

Oksanen, Eric

2006 Proposed Fiber Optic Conduit Route at the Aquarena River Center and Golf Course, San Marcos, Hays County, Texas. Technical Report No. 22. Center for Archaeological Studies, Texas State University-San Marcos.

2008 Archaeological Investigations at the Icehouse Site, 41HY161: A Revaluation of Early Archaic Technology, Subsistence, and Settlement along the Balcones Escarpment and Central Texas. Unpublished Master's thesis, Department of Anthropology, Texas State University-San Marcos.

Patterson, Leland W.

1995 The Archeology of Southeast Texas. Bulletin of the Texas Archeology Society 66:239-264.

Prewitt, Elton R.

1974 Preliminary Archeological Investigations in the Rio Grande Delta Area of Texas. Bulletin of the Texas Archeological Society 45:55-65. 
Ramsey, D.

1997 Archaeological Survey of Aquarena Springs Park, Hays County, Texas. Manuscript on file, Anthropology Department, Southwest Texas State University, San Marcos.

Ricklis, Robert A.

1994 Toyah Components: Evidence for Occupation in the Project Area During the Latter Part of the Late Prehistoric Period. In Archaic and Late Prehistoric Human Ecology in the Middle Onion Creek Valley, Hays County, Texas, by Robert A. Ricklis and Michael B. Collins, pp. 207-316. Studies in Archeology 19. Texas Archeological Research Laboratory, The University of Texas at Austin.

2005 Analysis of Findings at the Buckeye Knoll Site (41TV98), Victoria County, Texas. Quarterly Report No. 5. Report submitted to the United States Army Corps of Engineers. Electronic document, http://www.swg.usace.army.mil/pe/41VT98/ (accessed 1 September, 2009).

Ringstaff, C. W.

2000 A Study of Landform Evolution and Archaeological Preservation at Site 41HY165, San Marcos, Texas. Unpublished Master's thesis, Department of Geography, Southwest Texas State University, San Marcos.

Shand, Jean Akridge (compiler)

1990 Echoes in Your Memories of San Marcos Baptist Academy. Nel-Mar Publications, Canyon Lake, Texas.

Shiner, J. L.

1979 Survey and Testing of the Ice House Site: San Marcos, Hays County, Texas. Unpublished manuscript on file, Southern Methodist University, Dallas.

1981 History, Economy, and Magic at a Fresh Water Spring. In The Realms of Gold, Proceedings of the Tenth Conference on Underwater Archaeology, edited by W. A. Cockrell, pp. 202-203. Fathom Eight, San Marino, California.

1983 Large Springs and Early American Indians. Plains Anthropologist 28:99:1-7.

1984 A Reply of Johnson and Holliday. Plains Anthropologist 29:103:71-72.

Smith, Holland P.

1954 San Marcos Baptist Academy. Unpublished Master's thesis, Baylor University, Waco.

Soucie, Shawn, and David L. Nickels

2003 Archaeological Monitoring of a Tree Planting Project and Installation of the Front Door Welcoming Drive for Texas State University-San Marcos, Hays County, Texas. Technical Report No. 11. Center for Archaeological Studies, Texas State University-San Marcos.

Soucie, Shawn, David L. Nickels, Kevin L. Shubert, and Colby J. Mischefsky

2004 Archaeological Trench Monitoring at the Aquarena Springs Golf Course, San Marcos, Hays County, Texas. Technical Report No. 16. Center for Archaeological Studies, Texas State University-San Marcos. 
Southern Messenger

1915 "New Church dedicated at San Marcos, Texas." 21 October:1-2.

Spearing, Darwin

1991 Roadside Geology of Texas. Mountain Press Publishing, Missoula, Montana.

Stanford, Dennis, and Frank Broilo

1981 Frank's Folsom Campsite. The Artifact 19(3-4):1-11.

Story, Dee Ann

1985 Adaptive Strategies of Archaic Cultures of the West Gulf Coastal Plain. In Prehistoric Food Production in North America, edited by Richard I. Ford, pp. 19-56. Anthropological Papers No. 75. Museum of Anthropology, University of Michigan, Ann Arbor.

Stull, Kyra

2009 Bioarchaeological Report on Human Remains from 41HY161. Report on file at the Center for Archaeological Studies, Texas State University-San Marcos.

Takac, P. R.

1990 "Homes Bases" and the Paleoindian/Archaic transition in Central Texas. Paper presented at the 55th Annual SAA Meeting, Las Vegas, Nevada.

1991a Underwater Excavations at Spring Lake: A Paleoindian site in Hays County, Texas. Current Research in the Pleistocene 8:46-48.

1991b Paleoindian Occupations at Spring Lake, Hays Co., Texas. Dissertation Research Proposal. Submitted to the Faculty, Department of Anthropology, Southern Methodist University, Dallas.

Toma, Kristine

2009 Landmark Purchase 30 Years Ago. Hillviews Spring/Summer 09, Texas State University-San Marcos.

Tomka, Steve A., and John Leffler

1998 A Cultural Overview and Assessment of Balcones Canyonlands National Wildlife Refuge. Special Report No. 24. Center for Archaeological Research, The University of Texas at San Antonio.

Turner, Ellen S., and Thomas R. Hester

1993 A Field Guide to Stone Artifacts of Texas Indians. 2nd ed. Texas Monthly Field Guide Series. Gulf Publishing Company, Houston.

Warren, James E.

1977a TexSite Site Survey Form. Texas Historical Commission Texas Archeological Sites Atlas, “41HY133," http://nueces.thc.state.tx.us/ (accessed April 12, 2010). 
1977b TexSite Site Survey Form. Texas Historical Commission Texas Archeological Sites Atlas, “41HY135," http://nueces.thc.state.tx.us/ (accessed April 12, 2010).

Weir, Frank A.

1976 The Central Texas Archaic. Unpublished PhD dissertation, Anthropology Department, Washington State University, Pullman.

Wenke, Robert J.

1990 Patterns in Prehistory: Humankind's First Three Million Years. 3rd ed. Oxford University Press, Oxford, England.

Yelacic, David M., and Jon. C. Lohse

2008 Results of Archaeological Survey for the Freeman Ranch Forensic Studies Research Facility in Hays County, Texas. Technical Report No. 32. Center for Archaeological Studies, Texas State University-San Marcos.

2010 Results of Archaeological Survey at the 251-acre Spring Lake Preserve, San Marcos, Hays County, Texas. Technical Report No. 41. Center for Archaeological Studies, Texas State University-San Marcos.

Yelacic, David M., R. Zac Selden, and Jon C. Lohse

2008 Results of Archaeological Monitoring at the Fish Ponds, Texas State University-San Marcos, Hays County, Texas. Technical Report No. 33. Center for Archaeological Studies, Texas State University-San Marcos. 
Appendix A

\section{Center for Commercialization Project Shovel Test Excavations}




\begin{tabular}{|c|c|c|c|c|c|c|}
\hline Site & TR No. & ST No. & $\begin{array}{l}\text { Depth } \\
\text { (cmbs) }\end{array}$ & Munsell & Texture & Cultural Material \\
\hline $41 \mathrm{HY} 477$ & 1 & 1 & $0-20$ & 10 YR 4/3 & $\begin{array}{l}\text { Sandy } \\
\text { Loam }\end{array}$ & $\begin{array}{c}1 \text { Nail, } 1 \text { Clear Glass } \\
\text { Shard }\end{array}$ \\
\hline 41HY477 & 1 & 1 & $20-40$ & 10 YR 4/3 & $\begin{array}{l}\text { Sandy } \\
\text { Loam }\end{array}$ & $\begin{array}{l}1 \text { Bone, } 1 \text { Clear } \\
\text { Glass Shard }\end{array}$ \\
\hline $41 \mathrm{HY} 477$ & 1 & 1 & $40-60$ & 10 YR 4/3 & $\begin{array}{l}\text { Sandy } \\
\text { Loam }\end{array}$ & None \\
\hline 41HY477 & 1 & 1.1 & $0-20$ & 10 YR 4/1 & $\begin{array}{l}\text { Sandy } \\
\text { Loam }\end{array}$ & None \\
\hline 41HY477 & 1 & 1.2 & $0-20$ & $10 \mathrm{YR} 4 / 2$ & $\begin{array}{l}\text { Sandy } \\
\text { Loam }\end{array}$ & None \\
\hline $41 \mathrm{HY} 477$ & 1 & 1.2 & $20-40$ & 10 YR 4/2 & $\begin{array}{l}\text { Sandy } \\
\text { Loam }\end{array}$ & None \\
\hline $41 \mathrm{HY} 477$ & 1 & 1.2 & $40-50$ & 10 YR 4/2 & $\begin{array}{l}\text { Sandy } \\
\text { Loam }\end{array}$ & None \\
\hline 41HY477 & 1 & 1.3 & $0-20$ & 10 YR 4/1 & $\begin{array}{l}\text { Sandy } \\
\text { Loam }\end{array}$ & None \\
\hline 41HY477 & 1 & 1.4 & $0-20$ & 10 YR 4/2 & $\begin{array}{l}\text { Sandy } \\
\text { Loam }\end{array}$ & 1 Ceramic \\
\hline $41 \mathrm{HY} 477$ & 1 & 1.4 & $20-40$ & 10 YR 4/2 & $\begin{array}{l}\text { Sandy } \\
\text { Loam }\end{array}$ & $\begin{array}{l}2 \text { Ceramic, } 1 \text { Blue } \\
\text { Glass Shard and } 1 \\
\text { Clear Glass Shard } \\
\text { (Not Collected) }\end{array}$ \\
\hline 41HY477 & 1 & 1.4 & $40-60$ & $\begin{array}{c}\text { Mottling at } \\
60 \mathrm{~cm} \text {, mix } \\
\text { of } 10 \mathrm{YR} \\
4 / 2 \text { and } \\
6 / 6\end{array}$ & $\begin{array}{l}\text { Sandy } \\
\text { Loam with } \\
\text { Clay } \\
\text { Deposits } \\
\text { from } 50- \\
60 \mathrm{~cm}\end{array}$ & None \\
\hline $41 \mathrm{HY} 477$ & 1 & 1.5 & $0-20$ & 10 YR 3/2 & $\begin{array}{l}\text { Sandy } \\
\text { Loam }\end{array}$ & Glass, Earthenware \\
\hline $41 \mathrm{HY} 477$ & 1 & 1.5 & $20-40$ & 10 YR 3/2 & $\begin{array}{l}\text { Sandy } \\
\text { Loam }\end{array}$ & None \\
\hline 41HY477 & 1 & 1.5 & $40-60$ & 10 YR 3/2 & $\begin{array}{l}\text { Sandy } \\
\text { Loam }\end{array}$ & None \\
\hline 41HY477 & 1 & 1.6 & $0-20$ & 10 YR 3/2 & $\begin{array}{l}\text { Sandy } \\
\text { Loam }\end{array}$ & Glass, Whiteware \\
\hline 41HY477 & 1 & 1.7 & $0-20$ & 10 YR 4/2 & $\begin{array}{l}\text { Sandy } \\
\text { Loam }\end{array}$ & $\begin{array}{c}1 \text { Clear Glass Shard } \\
\text { (Not Collected) }\end{array}$ \\
\hline $41 \mathrm{HY} 477$ & 1 & 1.7 & $20-40$ & $10 \mathrm{YR} 4 / 2$ & $\begin{array}{l}\text { Sandy } \\
\text { Loam }\end{array}$ & $\begin{array}{c}2 \text { Clear Glass Shards } \\
\text { (Not Collected) }\end{array}$ \\
\hline $41 \mathrm{HY} 477$ & 1 & 1.7 & $40-50$ & 10 YR 4/2 & $\begin{array}{l}\text { Sandy } \\
\text { Loam }\end{array}$ & None \\
\hline 41HY477 & 1 & 1.8 & $0-20$ & 10 YR 4/2 & $\begin{array}{l}\text { Sandy } \\
\text { Loam }\end{array}$ & None \\
\hline
\end{tabular}




\begin{tabular}{|c|c|c|c|c|c|c|}
\hline Site & TR No. & ST No. & $\begin{array}{c}\text { Depth } \\
\text { (cmbs) }\end{array}$ & Munsell & Texture & Cultural Material \\
\hline $41 \mathrm{HY} 477$ & 1 & 1.8 & $20-40$ & $10 \mathrm{YR}$ 4/2 & $\begin{array}{l}\text { Sandy } \\
\text { Loam }\end{array}$ & None \\
\hline $41 \mathrm{HY} 477$ & 1 & 1.8 & $40-50$ & 10 YR 4/2 & $\begin{array}{l}\text { Sandy } \\
\text { Loam }\end{array}$ & None \\
\hline 41HY477 & 1 & 1.9 & $0-20$ & 10 YR 3/2 & Loam & Earthenware \\
\hline $41 \mathrm{HY} 477$ & 1 & 1.9 & $20-40$ & 10 YR 3/2 & Loam & None \\
\hline $41 \mathrm{HY} 477$ & 1 & 1.9 & $40-50$ & 10 YR 3/2 & Loam & None \\
\hline $41 \mathrm{HY} 477$ & 1 & 1.1 & $0-20$ & 10 YR 3/2 & Loam & Whiteware, Glass \\
\hline 41HY477 & & & $20-40$ & 10 YR 3/2 & Loam & None \\
\hline 41HY477 & & & $40-50$ & 10 YR 3/2 & Loam & None \\
\hline 41HY477 & 1 & 1.11 & $0-20$ & 10 YR 3/1 & $\begin{array}{l}\text { Sandy } \\
\text { Loam }\end{array}$ & None \\
\hline $41 \mathrm{HY} 477$ & 1 & 1.11 & $20-40$ & 10 YR 3/1 & $\begin{array}{l}\text { Sandy } \\
\text { Loam }\end{array}$ & None \\
\hline $41 \mathrm{HY} 477$ & 1 & 1.11 & $40-60$ & 10 YR 3/1 & $\begin{array}{l}\text { Sandy } \\
\text { Loam }\end{array}$ & None \\
\hline $41 \mathrm{HY} 477$ & 1 & 1.12 & $0-20$ & $10 \mathrm{YR} 3 / 1$ & $\begin{array}{l}\text { Sandy } \\
\text { Loam }\end{array}$ & Glass \\
\hline $41 \mathrm{HY} 477$ & 1 & 1.12 & $20-40$ & $10 \mathrm{YR} 3 / 1$ & $\begin{array}{l}\text { Sandy } \\
\text { Loam }\end{array}$ & None \\
\hline $41 \mathrm{HY} 477$ & 1 & 1.12 & $40-50$ & 10 YR 3/1 & Clay & None \\
\hline $\mathrm{N} / \mathrm{A}$ & 1 & 2 & $0-20$ & 7.5 YR 4/3 & Clay & None \\
\hline $\mathrm{N} / \mathrm{A}$ & 1 & 2 & $20-40$ & 7.5 YR 4/3 & Clay & None \\
\hline $\mathrm{N} / \mathrm{A}$ & 1 & 2 & $40-50$ & 7.5 YR 4/3 & Clay & None \\
\hline $\mathrm{N} / \mathrm{A}$ & 2 & 1 & $0-20$ & 10 YR 3/1 & Silt Loam & None \\
\hline N/A & 2 & 1 & $20-40$ & $\begin{array}{l}10 \text { YR 3/1 } \\
10 \text { YR 3/2 }\end{array}$ & Silt Loam & None \\
\hline N/A & 2 & 1 & $40-60$ & 10 YR 3/2 & $\begin{array}{l}\text { Clay } \\
\text { Loam }\end{array}$ & None \\
\hline $\mathrm{N} / \mathrm{A}$ & 2 & 1 & $60-70$ & 10 YR 3/2 & $\begin{array}{c}\text { Clay } \\
\text { Loam }\end{array}$ & None \\
\hline $\mathrm{N} / \mathrm{A}$ & 2 & 2 & $0-20$ & 10 YR $3 / 2$ & Silt Loam & None \\
\hline $\mathrm{N} / \mathrm{A}$ & 2 & 2 & $20-40$ & 10 YR $3 / 2$ & Silt Loam & None \\
\hline
\end{tabular}




\begin{tabular}{|c|c|c|c|c|c|c|}
\hline Site & TR No. & ST No. & $\begin{array}{l}\text { Depth } \\
\text { (cmbs) }\end{array}$ & Munsell & Texture & Cultural Material \\
\hline $\mathrm{N} / \mathrm{A}$ & 2 & 2 & $40-60$ & 10 YR 3/2 & Silt Loam & None \\
\hline $\mathrm{N} / \mathrm{A}$ & 2 & 2 & $60-70$ & 10 YR 3/2 & Silt Loam & None \\
\hline $\mathrm{N} / \mathrm{A}$ & 3 & 1 & $0-20$ & 10 YR $4 / 3$ & $\begin{array}{l}\text { Clay } \\
\text { Loam }\end{array}$ & None \\
\hline $\mathrm{N} / \mathrm{A}$ & 3 & 1 & $20-40$ & 10 YR 4/3 & $\begin{array}{l}\text { Clay } \\
\text { Loam }\end{array}$ & None \\
\hline $\mathrm{N} / \mathrm{A}$ & 3 & 1 & $40-60$ & 10 YR 4/3 & $\begin{array}{l}\text { Clay } \\
\text { Loam }\end{array}$ & None \\
\hline $\mathrm{N} / \mathrm{A}$ & 4 & 1 & $0-20$ & 10 YR 3/1 & Silt Loam & None \\
\hline $\mathrm{N} / \mathrm{A}$ & 4 & 1 & $20-40$ & 10 YR 3/1 & Silt Loam & None \\
\hline $\mathrm{N} / \mathrm{A}$ & 4 & 1 & $40-60$ & 10 YR 3/1 & Silt Loam & None \\
\hline $\mathrm{N} / \mathrm{A}$ & 5 & 1 & $0-20$ & 10 YR 4/1 & Clay & None \\
\hline $\mathrm{N} / \mathrm{A}$ & 5 & 1 & $20-40$ & 10 YR 4/1 & Clay & None \\
\hline $\mathrm{N} / \mathrm{A}$ & 5 & 1 & $40-50$ & 10 YR 4/1 & Clay & None \\
\hline $\mathrm{N} / \mathrm{A}$ & 5 & 2 & $0-20$ & 10 YR 3/1 & Clay & None \\
\hline $\mathrm{N} / \mathrm{A}$ & 5 & 2 & $20-40$ & 10 YR 3/1 & Clay & $\begin{array}{c}1 \text { Clear Glass Shard } \\
\text { (Not Collected) }\end{array}$ \\
\hline $\mathrm{N} / \mathrm{A}$ & 5 & 2 & $40-50$ & 10 YR 3/1 & Clay & None \\
\hline $\mathrm{N} / \mathrm{A}$ & 6 & 1 & $0-20$ & 10 YR 3/1 & Clay & None - Disturbed \\
\hline $\mathrm{N} / \mathrm{A}$ & 6 & 1 & $20-40$ & 10 YR $3 / 1$ & Clay & None - Disturbed \\
\hline $\mathrm{N} / \mathrm{A}$ & 6 & 1 & $40-50$ & 10 YR 3/1 & Clay & None - Disturbed \\
\hline $\mathrm{N} / \mathrm{A}$ & 6 & 2 & $0-20$ & 10 YR 4/2 & Clay & None \\
\hline $\mathrm{N} / \mathrm{A}$ & 6 & 2 & $20-40$ & $\begin{array}{c}10 \text { YR 4/2 } \\
\& 10 \text { YR } \\
5 / 6 \\
\end{array}$ & Clay & None \\
\hline $\mathrm{N} / \mathrm{A}$ & 6 & 2 & $40-50$ & 10 YR 4/2 & Clay & None \\
\hline $\mathrm{N} / \mathrm{A}$ & 7 & 1 & $0-20$ & 10 YR 3/1 & Clay & None \\
\hline $\mathrm{N} / \mathrm{A}$ & 7 & 1 & $20-40$ & 10 YR 3/1 & Clay & None \\
\hline $\mathrm{N} / \mathrm{A}$ & 7 & 1 & $40-50$ & 10 YR 3/1 & Clay & None \\
\hline
\end{tabular}




\begin{tabular}{|c|c|c|c|c|c|c|}
\hline Site & TR No. & ST No. & $\begin{array}{c}\text { Depth } \\
\text { (cmbs) }\end{array}$ & Munsell & Texture & Cultural Material \\
\hline $\mathrm{N} / \mathrm{A}$ & 8 & 1 & $0-20$ & 10 YR 3/1 & Clay & None \\
\hline $\mathrm{N} / \mathrm{A}$ & 8 & 1 & $20-40$ & 10 YR 3/1 & Clay & None \\
\hline $\mathrm{N} / \mathrm{A}$ & 8 & 1 & $40-50$ & 10 YR 3/1 & Clay & None \\
\hline $\mathrm{N} / \mathrm{A}$ & 9 & 1 & $0-20$ & 10 YR 3/1 & Clay & None \\
\hline $\mathrm{N} / \mathrm{A}$ & 9 & 1 & $20-40$ & 10 YR 3/1 & Clay & None \\
\hline $\mathrm{N} / \mathrm{A}$ & 9 & 1 & $40-50$ & 10 YR $3 / 2$ & Clay & None \\
\hline N/A & 9 & 2 & $0-20$ & $\begin{array}{c}7.5 \mathrm{YR} \\
2.5 / 1\end{array}$ & Clay & None \\
\hline $\mathrm{N} / \mathrm{A}$ & 9 & 2 & $20-40$ & $\begin{array}{c}7.5 \mathrm{YR} \\
2.5 / 1\end{array}$ & Clay & None \\
\hline $\mathrm{N} / \mathrm{A}$ & 9 & 2 & $40-50$ & $\begin{array}{c}7.5 \mathrm{YR} \\
2.5 / 1 \\
\end{array}$ & Clay & None \\
\hline $\mathrm{N} / \mathrm{A}$ & 10 & 1 & $0-20$ & 10 YR 3/1 & Clay & None \\
\hline $\mathrm{N} / \mathrm{A}$ & 10 & 1 & $20-40$ & 10 YR 3/1 & Clay & None \\
\hline $\mathrm{N} / \mathrm{A}$ & 11 & 1 & $0-20$ & 10 YR 4/1 & Clay & None \\
\hline $\mathrm{N} / \mathrm{A}$ & 11 & 1 & $20-30$ & $\begin{array}{c}10 \mathrm{YR} 4 / 1 \\
\& 2.5 \mathrm{YR} \\
5 / 2 \\
\end{array}$ & $\begin{array}{c}\text { Mottled } \\
\text { Clay }\end{array}$ & None \\
\hline $\mathrm{N} / \mathrm{A}$ & 11 & 2 & $0-20$ & 10 YR 4/1 & Clay & None \\
\hline N/A & 11 & 2 & $20-40$ & 10 YR 4/1 & $\begin{array}{c}\text { Compact } \\
\text { Clay }\end{array}$ & None \\
\hline $\mathrm{N} / \mathrm{A}$ & 12 & 1 & $0-20$ & 10 YR 4/1 & Clay & None \\
\hline $\mathrm{N} / \mathrm{A}$ & 12 & 1 & $20-40$ & 10 YR 4/1 & Clay & None \\
\hline N/A & 13 & 1 & $0-20$ & 10 YR 3/1 & $\begin{array}{c}\text { Gravel } \\
\text { Clay }\end{array}$ & None \\
\hline N/A & 13 & 1 & $20-40$ & 10 YR 3/1 & $\begin{array}{c}\text { Gravel } \\
\text { Clay }\end{array}$ & None \\
\hline
\end{tabular}




\section{Appendix B}

\section{Center for Commercialization Project THC Clearance Letter}




\title{
Texas State University $\mid$ san marcos
}

18 August, 2010

Center for Archaeological Studies

\author{
Mark Denton \\ Texas Historical Commission \\ 1511 North Colorado St. \\ Austin, TX 78701-1664
}
6or University Drive
San Marcos, Texas 78666-4616
office: 512.245 .2724

fax: 512.245 .2763

\section{Re: Center for Research Commercialization, Texas State University-San Marcos}

\section{Dear Mark,}

Texas State University-San Marcos is in the process of developing a 38-acre tract of land in Hays County into a Center for Research Commercialization. Your office was previously contacted about this project as the University was seeking federal grant support in partnership with the City of San Marcos from the Economic Development Administration. You responded concerning the need for a cultural resources survey (letter dated 24 May, 2010, from Mark Denton to Terry Golding). Since that time, the EDA proposal was awarded, meaning that federal monies will be part of the project development.

Under the terms of the Memorandum of Agreement between the University and THC, CAS conducted the archaeological field survey in July (earlier monitoring of geotechnical boring was performed in February of this year). This work was completed before federal involvement was clarified for the project, and so was conducted under Annual Antiquities permit (No. 5509). Our work reported a single historic site, $41 \mathrm{HY} 477$ that appears to be the remains of outbuildings associated with a dairy farm that was formerly in operation in this area. An intact feature, a stone-lined cistern, is present. We performed some archival research into the background of land use and ownership for the plot, and found that the site was never occupied by a residence, but rather was a dairy farm for a number of years in the early part of the twentieth century. We also failed to identify any significant persons associated with the tract. Considering that the site does not represent any residential activity and that our archival work (described below) does not identify any prominent person who was formerly associated with the site, CAS recommends that the site is not eligible for listing to the National Register of Historic Places, nor is it worth of being designated a State Archeological Landmark.

CAS suggests that the proposed undertaking will similarly have no negative impact whatsoever on historic properties. No standing buildings are located within the project area, and no historically significant buildings are located and visible within several hundred feet of the project area (Figure 1). Additionally, an aerial photo from 1952 was reviewed, and this image, too, shows no standing architecture near the proposed project area (Figure 2). 


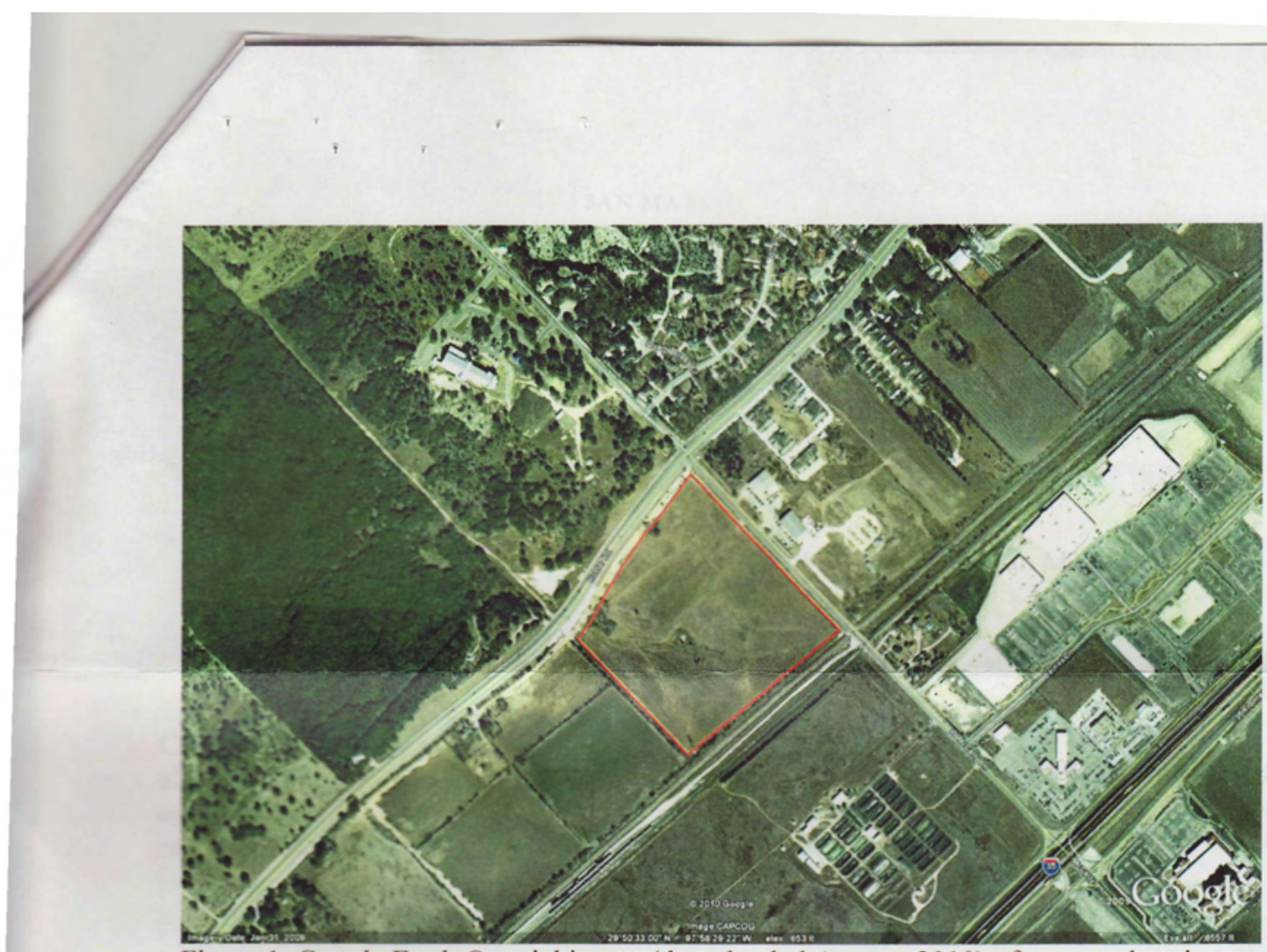

Figure 1. Google Earth (C) aerial image (downloaded August, 2010) of proposed project area, outlined in red, at the southern corner of the intersection of McCarty Road and Hunter Road, showing wooded spaces, agricultural pasture land, and recent constructions on surrounding tracts of land.

Below, the procedures and findings of the pedestrian survey and archival research are presented. Based on the results of this work, along with the lack of associated or any nearby architecture, CAS recommends full regulatory clearance for this undertaking to proceed without future concern for its impact on potentially significant cultural resources. Work on this project was carried out by Antonio Padilla, who served as Project Archaeologist and wrote the majority of the following report, assisted by CAS staff archaeologist Sarah Scogin. Julian Sitters conducted the monitoring, which is also described herein.

Please do not hesitate to contact me if you have any questions about this work or our findings. Thank you for your consideration, and we look forward to your response to this undertaking.

Sincerely yours,

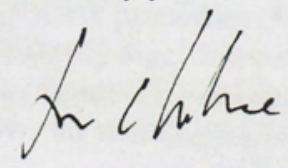

Jon C. Lohse, Ph.D.

Director, Center for Archaeological Studies

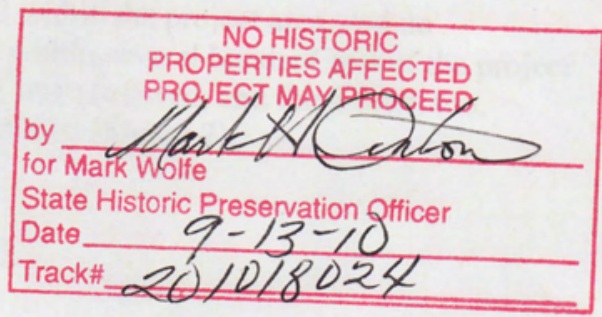




\section{Appendix C \\ Performing Arts Center Complex Backhoe Trench Technical Descriptions}

The following Tables C-1 through C-10 supply technical descriptions for a total of 10 backhoe trenches excavated, monitored, and recorded in association with the construction of the University's proposed Performing Arts Center Complex. All excavations were terminated at sterile, archaeologically insignificant subsoils, and all sediments and soils described below are calcareous unless otherwise noted. 


\section{BHT 1}

- Described by: David Yelacic and Jacob Hooge

- Excavated on: 11 September 2010

- Location: Sterry Hall Parking Lot

- Remarks: South wall exposure description; at top (westernmost portion) of parking lot; trench oriented perpendicular to S. LBJ and parallel to slope; historic artifacts encountered 1-2 ft ( $\sim 30$ to 60 $\mathrm{cm})$ below surface and prehistoric artifacts found 2-4 ft below surface ( $\sim 60$ to $120 \mathrm{~cm}$ ).

Table C-1. BHT 1 Description.

\begin{tabular}{|c|c|c|c|}
\hline Zone & $\begin{array}{l}\text { Depth } \\
\text { (cmbs) }\end{array}$ & Horizon & Description \\
\hline I & $0-14$ & Fill & Concrete/asphalt \\
\hline II & $14-37$ & Fill & $\begin{array}{c}\text { Three non-distinguished layers of construction fill beneath concrete and } \\
\text { asphalt, all containing }>50 \% \text { coarse fragments, abrupt smooth lower } \\
\text { boundary }\end{array}$ \\
\hline III & $37-72$ & $\mathrm{~A} / \mathrm{Ap}$ & $\begin{array}{l}\text { Dark olive brown ( } 2.5 \mathrm{Y} 3 / 3 \text { ) clay to loamy clay; firm; weak medium to coarse } \\
\text { subangular blocky structure; } 10 \% \text { coarse fragments; uncommon rootlets; } \\
\text { redoximorphic features (mostly oxidized iron mottles); clear smooth lower } \\
\text { boundary }\end{array}$ \\
\hline IV & $72-102$ & Btk1 & $\begin{array}{l}\text { Dark reddish brown (5YR 3/2) silty clay to clay; extremely firm; strong } \\
\text { coarse prismatic to strong coarse blocky structure; } 10 \% \text { coarse fragments; } \\
\text { uncommon rootlets; clay coats on ped faces; carbonate filaments; much dryer } \\
\text { and more well formed than above and below zones; gradual smooth lower } \\
\text { boundary }\end{array}$ \\
\hline IVa & $102-115$ & Btk2 & Same as IV except for carbonate is nodular \\
\hline $\mathrm{V}$ & $115-154$ & Bt-C & $\begin{array}{l}\text { Light olive brown }(2.5 \mathrm{Y} 5 / 6) \text { clay; extremely firm; strong medium to coarse } \\
\text { columnar to prismatic structure; }<5 \% \text { coarse fragments; clay and possible } \\
\text { manganese coats on ped faces; common redoximorphic features; gradual } \\
\text { smooth lower boundary }\end{array}$ \\
\hline VI & $154-210+$ & $\mathrm{C}$ & $\begin{array}{l}\text { Olive yellow (2.5Y 6/6) clay; very firm; strong coarse subangular blocky } \\
\text { structure (though structure is noted as difficult to see); }<5 \% \text { coarse } \\
\text { fragments; uncommon calcite crystals }\end{array}$ \\
\hline
\end{tabular}




\section{BHT 2}

- Described by: David Yelacic and Jacob Hooge

- Excavated on 11 September 2010

- Location: Sterry Hall Parking Lot

- Remarks: South wall exposure description; trench oriented parallel to slope.

Table C-2. BHT 2 Description.

\begin{tabular}{|c|c|c|c|}
\hline Zone & $\begin{array}{l}\text { Depth } \\
\text { (cmbs) }\end{array}$ & Horizon & Description \\
\hline Ia & $0-6$ & Fill & Concrete/asphalt \\
\hline I & $6-22$ & Fill & $\begin{array}{c}\text { Fill beneath concrete/asphalt; }<50 \% \text { coarse fragments; clear smooth lower } \\
\text { boundary }\end{array}$ \\
\hline II & $22-60$ & A & $\begin{array}{l}\text { Very dark gray }(2.5 \mathrm{Y} 3 / 1) \text { clay; firm; weak medium subangular blocky } \\
\text { structure; }<5 \% \text { coarse fragments; gradual smooth lower boundary }\end{array}$ \\
\hline III & $60-83$ & B & $\begin{array}{l}\text { Dark olive gray (5Y 3/2) clay; firm; strong coarse subangular blocky } \\
\text { structure; } 7-10 \% \text { coarse fragments; gradual smooth lower boundary }\end{array}$ \\
\hline IV & $83-130$ & Bk-C & $\begin{array}{c}\text { Light olive brown (2.5Y } 5 / 3) \text { clay; firm; strong coarse subangular blocky } \\
\text { structure; }<5 \% \text { coarse fragments; fine carbonate morphology; gradual } \\
\text { smooth lower boundary }\end{array}$ \\
\hline $\mathrm{V}$ & $130-160+$ & Bk-C & $\begin{array}{l}\text { Light yellowish brown }(2.5 \mathrm{Y} 6 / 4) \text { clay mottled with light brownish gray }(2.5 \mathrm{Y} \\
6 / 2) \text { clay and very dark gray }(2.5 \mathrm{Y} 3 / 1) \text { clay; firm; strong coarse subangular } \\
\text { blocky structure; }<2 \% \text { coarse fragments; fine carbonate morphology }\end{array}$ \\
\hline
\end{tabular}




\section{BHT 3}

- Described by: David Yelacic

- Excavated on: 11 September 2010

- Location: Sterry Hall Parking Lot

- Remarks: South wall exposure description; much of the deposits are historic/modern and appear (or smell) to be associated with a gas station that once occupied this location near the bottom (easternmost portion) of the parking lot; Zone II dips deeply into Zone III near the center of the exposure.

Table C-3. BHT 3 Description.

\begin{tabular}{|c|c|c|c|}
\hline Zone & $\begin{array}{l}\text { Depth } \\
\text { (cmbs) }\end{array}$ & Horizon & Description \\
\hline Ia & $0-10$ & Fill & Cement/asphalt \\
\hline I & $10-50$ & Fill & $\begin{array}{l}\text { Fill beneath concrete/asphalt; up to four non-distinguished layers of fill; } \\
\quad<50 \% \text { coarse fragments; saturated; clear smooth lower boundary }\end{array}$ \\
\hline II & $50-150$ & Fill & $\begin{array}{l}\text { Very dark grayish brown (10YR } 3 / 2) \text { clay; firm; moderate-strong medium to } \\
\text { coarse blocky structure; } 5 \% \text { coarse fragments; uncommon clay coats on peds; } \\
\text { strong odor of tar/petroleum; clear to gradual irregular lower boundary }\end{array}$ \\
\hline III & $150-180$ & Fill & $\begin{array}{l}\text { Olive (5Y 4/4) loamy clay; firm; moderate medium blocky structure; } 5-10 \% \\
\text { coarse fragments; carbonate filaments; sediment has greenish appearance; } \\
\text { gradual smooth lower boundary }\end{array}$ \\
\hline IV & $180-190+$ & $\mathrm{C}$ & $\begin{array}{l}\text { Olive yellow (2.5Y 6/8) clay; firm; moderate to strong medium to coarse } \\
\text { blocky structure; } 15 \% \text { coarse fragments; discontinuous clay coats on ped } \\
\text { faces; carbonate nodules }\end{array}$ \\
\hline
\end{tabular}




\section{BHT 4}

- Described by: David Yelacic and Jacob Hooge

- Excavated on: 18 Septemeber 2010

- Location: Falls Hall Parking Lot

- Remarks: South wall exposure description.

Table C-4. BHT 4 Description.

\begin{tabular}{|c|c|c|c|}
\hline Zone & $\begin{array}{l}\text { Depth } \\
\text { (cmbs) }\end{array}$ & Horizon & Description \\
\hline Ia & $0-7$ & Fill & Cement/asphalt \\
\hline I & $7-28$ & Fill & $\begin{array}{l}\text { "Caliche" fill beneath concrete/asphalt; }<50 \% \text { coarse fragments; abrupt } \\
\text { smooth lower boundary }\end{array}$ \\
\hline II & $28-124$ & $\mathrm{~A} / \mathrm{Ap}$ & $\begin{array}{l}\text { Olive brown }(2.5 \mathrm{Y} 4 / 3) \text { clay mottled with dark gray }(2.5 \mathrm{Y} \text { 4/1) clay; wet; } \\
\text { weak to moderate medium subangular blocky structure; } 5-10 \% \text { coarse } \\
\text { fragments; uncommon roots; common discontinuous clay coats on gravels; } \\
\text { historic stoneware at approximately } 70 \mathrm{cmbs} \text { and two concrete intrusions at } \\
\text { about } 80 \mathrm{cmbs} \text {; common redoximorphic features, shell present; clear smooth } \\
\text { lower boundary }\end{array}$ \\
\hline III & $124-145$ & $\mathrm{Bt}$ & $\begin{array}{l}\text { Light olive brown (2.5Y 5/3) clay mottled with very dark gray (10YR } \\
\text { 3/1) and gray ( } 2.5 \mathrm{Y} 5 / 1) \text { clays; wet; }<1 \% \text { coarse fragments; common } \\
\text { discontinuous clay coats on peds; clear smooth lower boundary }\end{array}$ \\
\hline IV & $145-164$ & $\mathrm{C}$ & $\begin{array}{l}\text { Yellow (10YR } 7 / 8) \text { clay mottled with gray ( } 2.5 \mathrm{Y} 5 / 1) \text { clay; firm; moderate to } \\
\text { strong coarse blocky structure; no coarse fragments; abundant clay coats on } \\
\text { peds; clear to abrupt smooth lower boundary }\end{array}$ \\
\hline $\mathrm{V}$ & $164-174$ & $\mathrm{C}$ & $\begin{array}{l}\text { Light gray to pale yellow ( } 2.5 \mathrm{Y} 7 / 2-3) \text { clay mottled with yellow (10YR } 7 / 8) \\
\text { and very dark gray (10YR 3/1) clays; firm; moderate to strong medium } \\
\text { blocky structure; no coarse fragments; common clay coats on peds; common } \\
\text { redoximorphic features; abrupt to clear smooth lower boundary }\end{array}$ \\
\hline VI & $174+$ & C & $\begin{array}{l}\text { Yellow (10YR } 7 / 8) \text { clay mottled with gray (2.5Y 5/1) clay; firm; platy } \\
\text { structure; no coarse fragments; common redoximorphic features }\end{array}$ \\
\hline
\end{tabular}




\section{BHT 5}

- Described by: David Yelacic and Jacob Hooge

- Excavated on: 18 September 2010

- Location: Falls Hall Parking Lot

- Remarks: South wall exposure description.

Table C-5. BHT 5 Description.

\begin{tabular}{|c|c|c|c|}
\hline Zone & $\begin{array}{l}\text { Depth } \\
\text { (cmbs) }\end{array}$ & Horizon & Description \\
\hline Ia & $0-4$ & Fill & Cement/asphalt \\
\hline I & $4-21$ & Fill & $\begin{array}{l}\text { "Caliche" fill beneath cement/asphalt; }>50 \% \text { coarse fragments; abrupt } \\
\text { smooth lower boundary }\end{array}$ \\
\hline II & $21-50$ & $\mathrm{~A} / \mathrm{Ap}$ & $\begin{array}{l}\text { Black (7/5YR 2.5/1) loamy clay; wet; barely discernable weak medium } \\
\text { blocky structure; } 10-20 \% \text { coarse fragments; occasional roots; round nails and } \\
\text { manufactured wood present; clear to gradual smooth lower boundary }\end{array}$ \\
\hline III & $50-187$ & $\mathrm{Bt}$ & $\begin{array}{l}\text { Very dark grayish brown (10YR 3/2) clay with some mottling of black (10YR } \\
\text { 2/1) clay; wet; strong medium to coarse subangular blocky structure; } 5 \% \\
\text { coarse fragments; abundant clay coats (some very distinct and "shiny") on } \\
\text { ped faces; gradual smooth lower boundary }\end{array}$ \\
\hline IV & $187+$ & $\mathrm{Bk} / \mathrm{C}$ & $\begin{array}{l}\text { Olive ( } 5 \text { Y } 5 / 3 \text { ) clay; firm; strong coarse subangular blocky structure; }<5 \% \\
\text { coarse fragments; occasional carbonate nodules and filaments }\end{array}$ \\
\hline
\end{tabular}




\section{BHT 6}

- Described by: David Yelacic and Jacob Hooge

- Excavated on: 18 September 2010

- Location: Falls Hall Parking Lot

- Remarks: South wall exposure description.

Table C-6. BHT 6 Description.

\begin{tabular}{|c|c|c|c|}
\hline Zone & $\begin{array}{l}\text { Depth } \\
\text { (cmbs) }\end{array}$ & Horizon & Description \\
\hline Ia & $0-4$ & Fill & Cement/asphalt \\
\hline I & $4-38$ & Fill & $\begin{array}{l}\text { "Caliche" fill beneath cement/asphalt; }<50 \% \text { coarse fragments; abrupt } \\
\text { smooth lower boundary }\end{array}$ \\
\hline II & $38-51$ & A & $\begin{array}{l}\text { Very dark gray }(10 \mathrm{YR} 3 / 1) \text { clay; firm; moderate coarse to very coarse } \\
\text { prismatic structure; }<5 \% \text { coarse fragments; uncommon roots; contains brick } \\
\text { fragments; gradual smooth lower boundary }\end{array}$ \\
\hline III & $51-83$ & Bt1 & $\begin{array}{c}\text { Very dark gray (7.5YR 3/1) clay; less firm; moderate medium to coarse } \\
\text { subangular blocky structure; }<5 \% \text { coarse fragments; clay coats on gravels; } \\
\text { gradual smooth lower boundary }\end{array}$ \\
\hline IV & $83-113$ & Bt2 & $\begin{array}{l}\text { Very dark grayish brown }(2.5 \mathrm{Y} 3 / 2) \text { clay; less firm; moderate medium } \\
\text { subangular blocky structure; }<5 \% \text { coarse fragments; clay coats on gravel; } \\
\text { possible krotovina present; gradual smooth lower boundary }\end{array}$ \\
\hline V & $\begin{array}{l}113- \\
200\end{array}$ & $\mathrm{Bt} 3$ & $\begin{array}{l}\text { Olive }(5 \mathrm{Y} 4 / 3) \text { clay; firm; moderate to strong coarse subangular blocky } \\
\text { structure; < } 5 \% \text { coarse fragments; abundant distinct clay coats on peds; } \\
\text { possible slickensides; possible krotovina; gradual smooth lower boundary }\end{array}$ \\
\hline VI & $200+$ & $\mathrm{Bk} / \mathrm{C}$ & $\begin{array}{c}\text { Olive brown }(2.5 \mathrm{Y} 4 / 3) \text { clay; firm; strong medium to coarse subangular } \\
\text { blocky structure; }<5 \% \text { coarse fragments; occasional carbonate nodules; clay } \\
\text { coats on gravel }\end{array}$ \\
\hline
\end{tabular}




\section{BHT 7}

- Described by: David Yelacic

- Excavated on: 25 September 2010

- Location: Butler Hall Parking Lot

- Remarks: East wall exposure description.

Table C-7. BHT 7 Description.

\begin{tabular}{|c|c|c|c|}
\hline Zone & $\begin{array}{l}\text { Depth } \\
\text { (cmbs) }\end{array}$ & Horizon & Description \\
\hline Ia & $0-4$ & Fill & Cement/asphalt \\
\hline I & $4-100$ & Fill & $\begin{array}{l}\text { Construction fill in three distinct layers (Base } 1,2 \text {, and } 3) \text {; all }>50 \% \\
\text { coarse fragments; Base } 2(20-50 \mathrm{cmbs}) \text { very wet; Base } 3(50-100 \mathrm{cmbs}) \\
\text { contains machine-made red bricks; very abrupt to abrupt lower boundary }\end{array}$ \\
\hline II & $100-105$ & $1 \mathrm{~A}$ & $\begin{array}{c}\text { Very dark gray }(10 \mathrm{YR} 3 / 1) \text { clayey silty loam; friable; weak fine to medium } \\
\text { blocky structure; }<10 \% \text { coarse fragments; abundant rootlets and possible } \\
\text { organic mat at upper boundary; organic-rich sediment; clear smooth lower } \\
\text { boundary }\end{array}$ \\
\hline III & $105-118$ & $1 \mathrm{Bt}$ & $\begin{array}{l}\text { Very dark grayish brown (10YR 3/2) clayey loam; friable; weak } \\
\text { to moderate medium subangular blocky structure; } 25-50 \% \text { coarse } \\
\text { fragments; clay coats on peds and gravels; common roots; clear smooth } \\
\text { lower boundary }\end{array}$ \\
\hline IV & $118-130$ & $1 \mathrm{C}$ & $\begin{array}{c}\text { Dark grayish brown }(10 \mathrm{YR} 4 / 2) \text { loam; friable; weak to moderate medium } \\
\text { subangular blocky structure; }<50 \% \text { coarse fragments; common roots; } \\
\text { very abrupt smooth lower boundary }\end{array}$ \\
\hline V & $130-190$ & $2 \mathrm{~A}$ & $\begin{array}{c}\text { Black (7.5YR 2.5/1) silty clayey loam; friable; moderate medium to coarse } \\
\text { subangular blocky structure; }<5 \% \text { coarse fragments; common roots; } \\
\text { gradual smooth lower boundary }\end{array}$ \\
\hline VI & $190+$ & $2 \mathrm{~B} / \mathrm{C}$ & $\begin{array}{c}\text { Olive brown (2.5Y 4/3) clay; firm; strong coarse subangular blocky } \\
\text { structure; }<5 \% \text { coarse fragments; carbonate filaments; clay coats on peds } \\
\text { and gravels }\end{array}$ \\
\hline
\end{tabular}




\section{BHT 8}

- Described by: David Yelacic

- Excavated on: 25 September 2010

- Location: Butler Hall Parking Lot

- Remarks: East wall exposure description; initial backhoe trench location was abandoned because an old and likely unused waterline was encountered.

Table C-8. BHT 8 Description.

\begin{tabular}{|c|c|c|c|}
\hline Zone & $\begin{array}{l}\text { Depth } \\
\text { (cmbs) }\end{array}$ & Horizon & Description \\
\hline Ia & $0-50$ & Fill & Cement/asphalt \\
\hline I & $50-74$ & Fill & $\begin{array}{c}\text { Construction base; gray (10YR } 5 / 1) \text { to strong brown ( } 7.5 \mathrm{YR} 5 / 6) \text { matrix with } \\
>50 \% \text { coarse fragments; very abrupt smooth lower boundary }\end{array}$ \\
\hline II & $74-82$ & Fill & $\begin{array}{c}\text { Black (7.5YR 2.5/1) clay; firm, strong medium subangular blocky structure; } \\
10-15 \% \text { coarse fragments; uncommon roots; very abrupt smooth lower } \\
\text { boundary }\end{array}$ \\
\hline III & $82-90$ & Fill & $\begin{array}{l}\text { Very dark grayish brown (10YR } 3 / 2) \text { clay mottled with yellow and very light } \\
\text { gray clays; firm; moderate to strong medium subangular blocky structure; } \\
25 \% \text { coarse fragments; abrupt smooth lower boundary }\end{array}$ \\
\hline IV & $90-105$ & $1 \mathrm{~A}$ & $\begin{array}{l}\text { Black (5YR 2.5/1) clayey loam to loamy clay; friable; weak to moderate } \\
\text { medium blocky structure; } 10 \% \text { coarse fragments; uncommon roots; } \\
\text { uncommon discontinuous clay coats on clasts; common shells and shell } \\
\text { fragments; gradual smooth lower boundary }\end{array}$ \\
\hline V & $105-120$ & $1 \mathrm{~B} / \mathrm{C}$ & $\begin{array}{c}\text { Very dark grayish brown (10YR 3/2) loamy clay; friable; moderate medium } \\
\text { blocky structure; } 10 \% \text { coarse fragments; common continuous clay coats on } \\
\text { peds and clasts; uncommon roots; uncommon shells; clear smooth lower } \\
\text { boundary }\end{array}$ \\
\hline VI & $120-170$ & $2 \mathrm{~A}$ & $\begin{array}{l}\text { Black (10YR 2/1) clay; firm; moderate to strong medium to coarse } \\
\text { subangular blocky structure; } 5 \% \text { coarse fragments; uncommon } \\
\text { discontinuous clay coats on peds; uncommon shells; gradual smooth lower } \\
\text { boundary }\end{array}$ \\
\hline VII & $170+$ & $2 \mathrm{~B} / \mathrm{C}$ & $\begin{array}{c}\text { Dark olive brown }(2.5 \mathrm{Y} 3 / 3) \text { clay; firm; strong coarse subangular blocky } \\
\text { structure; } 5 \% \text { coarse fragments; common continuous clay coats on peds and } \\
\text { clasts; uncommon shells }\end{array}$ \\
\hline
\end{tabular}




\section{BHT 9}

- Described by: David Yelacic

- Excavated on: 25 September 2010

- Location: Butler Hall Parking Lot

- Remarks: East wall exposure description; Zone I is not present in east wall, but is described from west wall profile.

Table C-9. BHT 9 Description.

\begin{tabular}{|c|c|c|c|}
\hline Zone & $\begin{array}{l}\text { Depth } \\
\text { (cmbs) }\end{array}$ & Horizon & Description \\
\hline Ia & $0-50$ & Fill & Cement/asphalt \\
\hline I & $20-50$ & A & $\begin{array}{l}\text { Very dark grayish brown }(10 \mathrm{YR} 3 / 2) \text { clay loam; friable; moderate medium } \\
\text { to coarse blocky structure; }<2 \% \text { coarse fragments; present in west wall } \\
\text { profile beneath asphalt; gradual smooth lower boundary }\end{array}$ \\
\hline II & $50-76$ & $\mathrm{AB}$ & $\begin{array}{l}\text { Brown (10YR 4/3) clay; friable; moderate medium to coarse blocky to } \\
\text { subangular blocky structure; }<2 \% \text { coarse fragments; common soft and } \\
\text { distinct redoximorphic freatures; gradual smooth lower boundary }\end{array}$ \\
\hline III & $76-104$ & $\mathrm{Bt}$ & $\begin{array}{c}\text { Olive brown }(2.5 \mathrm{Y} 4 / 4) \text { clay; friable; moderate to strong coarse subangular } \\
\text { blocky structure; }<2 \% \text { coarse fragments; common continuous clay coats on } \\
\text { peds and clasts; gradual smooth lower boundary }\end{array}$ \\
\hline IV & $104-170+$ & $\mathrm{Btk} / \mathrm{C}$ & $\begin{array}{l}\text { Olive brown (2.5Y 4/4) clay; firm; strong coarse subangular blocky } \\
\text { structure; } 10-15 \% \text { coarse fragments; soft distinct carbonate nodules; } \\
\text { uncommon discontinuous clay coats on peds }\end{array}$ \\
\hline
\end{tabular}




\section{BHT 10}

- Described by: David Yelacic

- Excavated on: 25 September 2010

- Location: Butler Hall Parking Lot

- Remarks: North wall exposure description; historic fill deposit, Zone IV, pinches out to the west and is not present in the southern profile; these sediments were much different than those encountered in every other backhoe trench - colluvial deposition dominates; a single projectile point was recovered from approximately $1-1.10 \mathrm{~m}$ below surface, and two bulk humate samples (90-95 cmbs and 120$125 \mathrm{cmbs}$ ) were collected for radiocarbon dating.

Table C-10. BHT 10 Description.

\begin{tabular}{|c|c|c|c|}
\hline Zone & $\begin{array}{l}\text { Depth } \\
\text { (cmbs) }\end{array}$ & Horizon & Description \\
\hline Ia & $0-4$ & Fill & Cement/asphalt \\
\hline $\mathrm{Ib}$ & $4-25$ & Fill & $\begin{array}{c}\text { Pink (5YR 8/3) gravelly fill; }>50 \% \text { coarse fragments; abrupt smooth lower } \\
\text { boundary }\end{array}$ \\
\hline I & $25-50$ & Fill & $\begin{array}{l}\text { Yellowish brown (10YR 5/6) gravelly fill; > }>50 \% \text { coarse fragments; clear } \\
\text { smooth lower boundary }\end{array}$ \\
\hline II & $50-62$ & Fill & Yellowish brown (10YR 5/8) gravelly fill; $>50 \%$ coarse fragments \\
\hline III & $62-70$ & Fill & $\begin{array}{c}\text { Very dark grayish brown (10YR 3/2) gravelly fill; }>50 \% \text { coarse fragments; } \\
\text { uncommon roots; abrupt smooth/irregular lower boundary }\end{array}$ \\
\hline IV & $70-78$ & Fill/Ap & $\begin{array}{l}\text { Black (10YR 2.5/1) gravelly matrix; }>50 \% \text { coarse fragments; uncommon } \\
\text { roots; contains oxidized metal and modern (round) nails; abrupt smooth/ } \\
\text { irregular lower boundary }\end{array}$ \\
\hline $\mathrm{V}$ & $78-108$ & A & $\begin{array}{l}\text { Very dark brown (10YR 2.5/2) clayey loam; extremely firm; weak fine } \\
\text { blocky structure; > } 25 \% \text { coarse fragments; some oxidized iron inclusions } \\
\text { and coats on clasts; uncommon roots; projectile point recovered from } \\
\text { around } 1 \mathrm{~m} \text { below surface; bulk humate sample (No. 1) collected from } \\
\text { 90-95 cmbs; gradual smooth lower boundary }\end{array}$ \\
\hline VI & $108-140$ & B & $\begin{array}{l}\text { Dark brown (10YR 3/3) clayey loam; firm; moderate medium subangular } \\
\text { blocky structure; } 25-40 \% \text { coarse fragments; common discontinuous } \\
\text { iron and clay coats on clasts and some peds; bulk humate sample (No. 2) } \\
\text { collected from } 120-125 \text { cmbs; gradual smooth lower boundary }\end{array}$ \\
\hline VII & $140-162+$ & $\mathrm{Bk} / \mathrm{C}$ & $\begin{array}{l}\text { Dark yellowish brown (10YR 4/4) clayey loam; firm; moderate medium } \\
\text { subangular blocky structure; } 10 \% \text { coarse fragments; uncommon iron coats } \\
\text { in pore spaces; common soft carbonate nodules }\end{array}$ \\
\hline
\end{tabular}




\section{Appendix D}

\section{Performing Arts Center Complex THC Clearance Letter}




\section{TEXAS $*$ STATE \\ UNIVERSITY \\ SAN MARCOS \\ The rising STAR of Texas}

1 November, 2010

Mark Denton

Texas Historical Commission

1511 North Colorado St.

Austin, TX 78701-1664

Re: Performing Arts Center, Texas State University-San Marcos

Dear Mark,

Texas State University-San Marcos is in the process of developing a new Performing Arts Center, located in the southeast corner of campus adjacent to the existing facility and to the historic fish ponds. Because this area was considered to have a relatively high probability for containing buried cultural deposits, CAS conducted a series of backhoe excavations across the area of potential effect. This work was carried out under the terms of our Memorandum of Agreement with the Texas Historical Commission and the Annual Permit that accompanies that agreement for the current calendar year (Permit No. 5509).

Our work recovered little in the way of cultural remains, and we conclude that the undertaking has virtually no chance of disturbing intact or meaningful archaeological materials. The APE is immediately adjacent to State Archeological Landmark 41HY161, but very few deposits potentially associated with that site were noted as extending into the APE. Based on our work, CAS recommends that undertaking be granted regulatory clearance to proceed under the Texas Antiquities Code.

Below, the procedures and findings of our backhoe survey are presented. Work on this project was carried out by Antonio Padilla, who served as Project Archaeologist and wrote the majority of the following report, assisted by CAS staff archaeologists Jacob Hooge and Veronic Suarez. David Yelacic compiled the geoarchaeological descriptions of the backhoe trench exposures.

Please do not hesitate to contact me if you have any questions about this work or our findings. Thank you for your consideration, and we look forward to your response to this undertaking.

Sincerely yours,

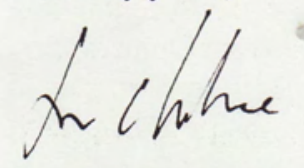

Jon C. Lohse, Ph.D.

Director, Center for Archaeological Studies

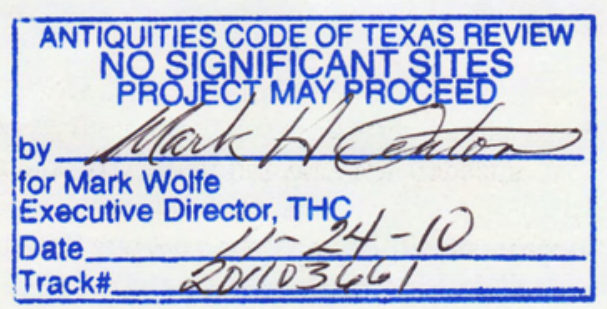

Center for Archakological Studies

6or University Drive | San Marcos, TeXas 78666-4616 | phone 512.245.2724 | fax 512.245.2763 | wwww.TXstate.edu

Texas State University-San Marcos, founded in 1899, is a member of The Texas State University System. 